\title{
CAMA
}

Centre for Applied Macroeconomic Analysis

\section{Weakness in Investment Growth: Causes, Implications and Policy Responses}

\section{CAMA Working Paper 19/2017 March 2017}

\section{Ayhan Kose}

World Bank, Development Prospects Group

Brookings Institution

CEPR and

Centre for Applied Macroeconomic Analysis, ANU

Franziska Ohnsorge

World Bank, Development Prospects Group

Lei Sandy Ye

World Bank, Development Prospects Group

Ergys Islamaj

World Bank, Development Prospects Group

\section{Abstract}

Investment growth in emerging market and developing economies has slowed sharply since 2010. This paper presents a comprehensive analysis of the causes and implications of this slowdown and presents a menu of policy responses to improve investment growth. It reports four main results. First, the slowdown has been broad-based and most pronounced in the largest emerging markets and in commodity exporters. Second, it reflects a range of obstacles: weak activity, negative terms-of-trade shocks, declining foreign direct investment inflows, elevated private debt burdens, heightened political risk, and adverse spillovers from major economies. Third, by slowing capital accumulation and technological progress embedded in investment, weak post-crisis investment growth has contributed to sluggish growth of potential output in recent years. Finally, although specific policy priorities depend on country circumstances, policymakers can boost investment both directly, through public investment, and indirectly, by encouraging private investment, including foreign direct investment, and by undertaking measures to improve overall growth prospects and the business climate. 


\section{Keywords}

emerging markets, developing economies, investment slowdown, policy space, infrastructure investment, monetary policy, fiscal policy, structural reforms

\section{JEL Classification}

E22, F2, F6, O1, O4

\section{Address for correspondence:}

(E) cama.admin@anu.edu.au

\section{ISSN 2206-0332}

The Centre for Applied Macroeconomic Analysis in the Crawford School of Public Policy has been established to build strong links between professional macroeconomists. It provides a forum for quality macroeconomic research and discussion of policy issues between academia, government and the private sector.

The Crawford School of Public Policy is the Australian National University's public policy school, serving and influencing Australia, Asia and the Pacific through advanced policy research, graduate and executive education, and policy impact. 


\title{
Weakness in Investment Growth: Causes, Implications and Policy Responses
}

March 2017

\section{Ayhan Kose, Franziska Ohnsorge, Lei Sandy Ye, and Ergys Islamaj ${ }^{*}$}

\begin{abstract}
Investment growth in emerging market and developing economies has slowed sharply since 2010. This paper presents a comprehensive analysis of the causes and implications of this slowdown and presents a menu of policy responses to improve investment growth. It reports four main results. First, the slowdown has been broad-based and most pronounced in the largest emerging markets and in commodity exporters. Second, it reflects a range of obstacles: weak activity, negative terms-of-trade shocks, declining foreign direct investment inflows, elevated private debt burdens, heightened political risk, and adverse spillovers from major economies. Third, by slowing capital accumulation and technological progress embedded in investment, weak post-crisis investment growth has contributed to sluggish growth of potential output in recent years. Finally, although specific policy priorities depend on country circumstances, policymakers can boost investment both directly, through public investment, and indirectly, by encouraging private investment, including foreign direct investment, and by undertaking measures to improve overall growth prospects and the business climate.
\end{abstract}

JEL Classification Numbers: E22, F2, F6, O1, O4

Keywords: emerging markets; developing economies; investment slowdown; policy space; infrastructure investment; monetary policy; fiscal policy; structural reforms

\footnotetext{
* Kose (World Bank, Development Prospects Group; Brookings Institution; CEPR; CAMA; akose@worldbank.org); Ohnsorge (World Bank, Development Prospects Group; fohnsorge@worldbank.org); Ye (World Bank, Development Prospects Group; lye1@worldbank.org); Islamaj (World Bank, Development Prospects Group; eislamaj@worldbank.org). This paper was prepared with contributions from Mai Anh Bui, Jongrim Ha, Raju Huidrom, Csilla Lakatos, Hideaki Matsuoka, Trang Nguyen, Yoki Okawa, Naotaka Sugawara, Congyan Tan, Ekaterine Vashakmadze, and Shu Yu. Mai Anh Bui, Collette Wheeler, Yirou Li, Liwei Liu, and Cristhian Vera Avellan provided excellent research assistance. We would like to thank for useful comments Carlos Arteta, Martin Baily, Eduardo Borensztein, Ajai Chopra, Kevin Clinton, Kemal Dervis, Graham Hacche, Raju Huidrom, Oliver Masetti, Ugo Panizza, David Robinson, Claudia Sepulveda, Marc Stocker, Zia Qureshi, Ekaterine Vashakmadze, Kei-Mu Yi, and our many colleagues at the World Bank. The findings, interpretations, and conclusions expressed in this article are entirely those of the authors. They do not necessarily represent the views of the World Bank, its Executive Directors, or the countries they represent. Figures and background data are available at www.worldbank.org/gep.
} 


\section{EXECUTIVE SUMMARY}

Slowing investment growth. Investment growth in emerging market and developing economies (EMDEs) has slowed sharply since 2010, declining from 10 percent, on average, in 2010 to 3.4 percent in 2015. Investment growth was not only well below its pre-crisis average, but was also below its long-term average in nearly 70 percent of EMDEs in 2015. Surveys of long-term forecasts suggest that investment weakness is expected to persist (Figure A1).

Factors associated with the slowdown. In commodity importers, slowing FDI inflows and spillovers from soft activity in major economies appeared to account for much of the slowdown in investment growth. In commodity exporters, a sharp terms of trade deterioration (for energy exporters) and mounting private debt burdens were the main factors associated with the slowdown in investment growth. Political and policy uncertainty has further contributed to lower investment growth in several EMDEs.

Spillovers. Over the past five years, advanced economy growth has repeatedly fallen short of expectations, partly because of crisis legacies. Sub-par growth and growth prospects in advanced-economy trading partners and source countries for FDI into EMDEs have slowed EMDE output growth. For every 1 percentage point lower output growth in the United States or Euro Area, EMDE output growth fell 0.8-1.3 percentage points within a year. EMDE investment growth responded about twice as strongly as EMDE output to declines in U.S. and Euro Area growth. Sluggish economic activity in major advanced economies has coincided with a policy-driven slowdown in investment growth in China. This has contributed to weakening global commodity prices and has weighed on growth in other EMDEs through inter-sectoral input-output links and, indirectly, via output growth spillovers.

"Investment-less" credit booms. Investment weakness has been set against the backdrop of exceptionally benign domestic (and global) financing conditions until late 2016. Policy interest rates of AE central banks are at or near record lows. Private credit growth in about $30 \mathrm{EMDEs}$ was near or above levels associated with credit booms at some point during 2010-15. Historically, around 40 percent of credit booms have coincided with investment surges. However, similar credit booms since 2010 have taken place with virtually no such investment surges but, instead, often with rapidly rising consumption.

Long-term implications of weak investment growth. By slowing capital accumulation and technological progress embedded in investment, weak post-crisis investment growth has contributed to lower potential output growth from pre-crisis rates. The slowdown in potential growth could be intensified if weakness in investment also sets back total factor productivity growth through a slowdown in embodied technological progress.

Policy responses. Policymakers can boost investment both directly, through public investment, and indirectly, by encouraging private investment, including foreign direct investment, and by undertaking measures to improve overall growth prospects and the business climate. Doing so directly through expanding public investment in infrastructure and human capital would help raise demand in the short-run, increase potential output in the long-run and improve the environment for private investment and trade. Public investment would also help close investment gaps targeted by the United Nations Sustainable Development Goals. More effective use of counter-cyclical fiscal and monetary policies can also promote private investment indirectly by strengthening output growth, especially in commodity-exporting EMDEs. These policies may be less effective, however, if employed to mitigate the impact of a persistent terms of trade shock or if there is limited fiscal space. In any event, to raise investment growth sustainably, such policies will need to be buttressed by structural reforms to encourage both domestic private and foreign direct investment. Historically, reform waves in EMDEs have been associated with higher investment and output growth. 


\section{Figure A1. Investment growth slowdown}

Investment growth in EMDEs has slowed sharply since the global financial crisis. In 2015, the share of EMDEs with investment growth below its long-term average reached its highest level except during global downturns. Long-term forecasts suggest continued weakness in investment growth. Weak investment growth has been accompanied by anemic productivity growth, compounding risks that the income catch-up of EMDEs to advanced economy (AE) levels may slow.

\section{A. Investment growth}

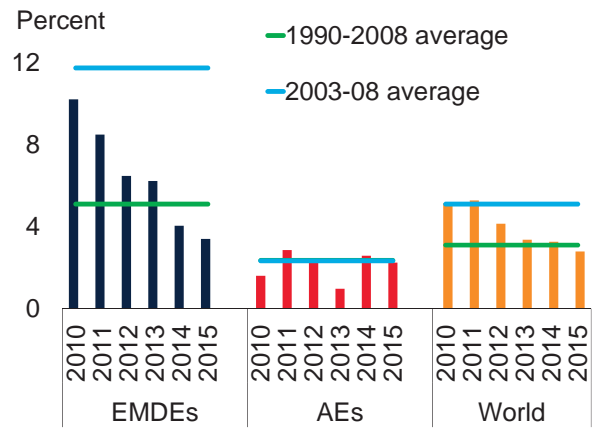

C. Share of EMDEs with investment growth below its long-term average

Percent of EMDEs

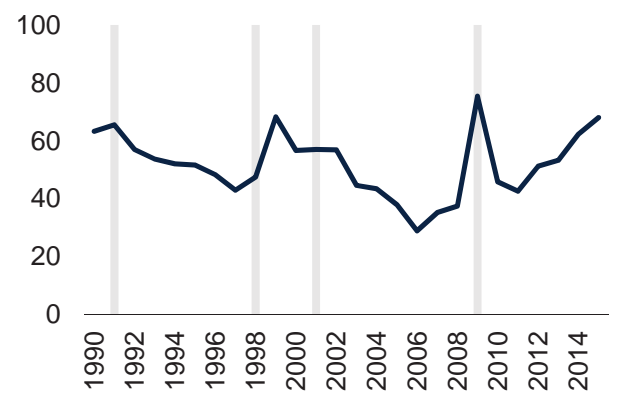

\section{E. Share of world investment}

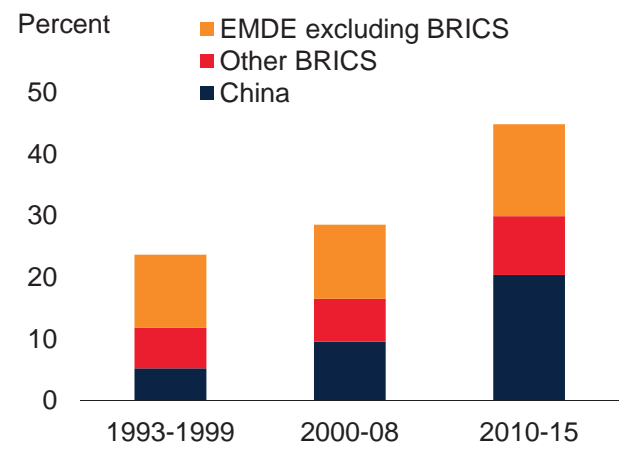

\section{B. Quarterly investment growth: EMDEs}

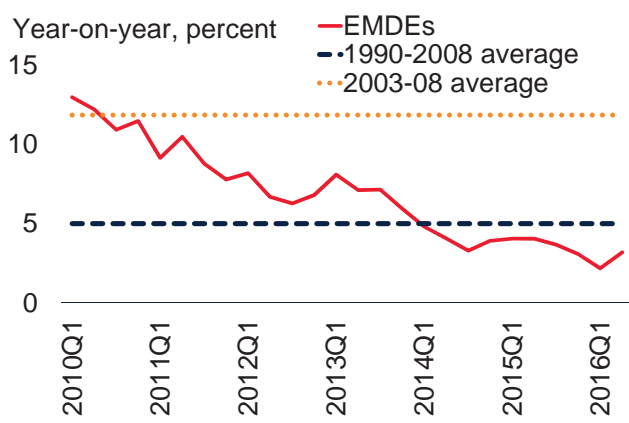

D. Five-year-ahead forecasts of investment growth Percent

$10 \quad-E M D E s-A E s-$ World

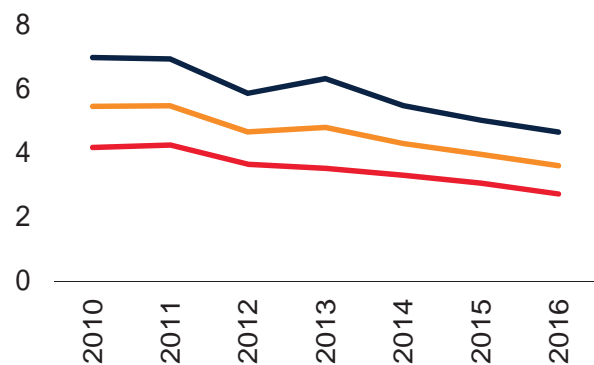

F. Change in TFP and investment growth, 2010-15 Percentage points

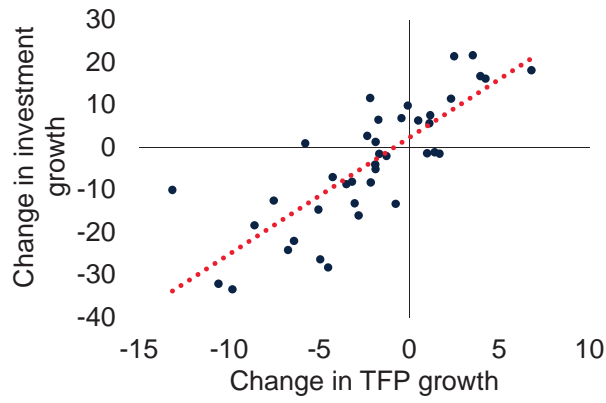

Sources: Consensus Economics; Haver Analytics; International Monetary Fund; Oxford Economics; Penn World Tables; World Development Indicators, World Bank.

A. Weighted averages. Long-term average starts in 1991 for EMDEs due to lack of earlier data.

B. Weighted averages. Includes 28 EMDEs with available quarterly data. Long-term averages start in 1991 for EMDEs and are based on annual data. Last observation is for Q2 2016.

C. Long-term averages are country-specific and refer to 1990-2008. Latest year is 2015.

D. Each line shows five-year-ahead Consensus Forecasts as of the latest available month in the year denoted. Unweighted averages of 21 EMDEs and 25 advanced economies. World sample includes 46 countries. Latest data is as of October 2016.

E. Each column shows the period average of the share of global investment contributed by each respective group denoted. The world sample includes 100 EMDEs and 34 AEs.

F. Correlation of change in investment growth from 2010-15 with change in TFP growth over the same period. Red dotted line denotes the linear regression line. Includes 40 EMDEs. 


\section{Introduction ${ }^{1}$}

Investment growth in emerging market and developing economies (EMDEs) has slowed sharply since 2010, declining from 10.2 percent, on average, in 2010 to 3.4 percent in 2015. ${ }^{2}$ It has likely decelerated by more than half a percentage point in 2016. Investment growth is now not only well below its pre-crisis average, but also below its long-term average in the highest share of EMDEs in 25 years with the exception of during serious global downturns. EMDEs with below long-term average investment growth account for 35 percent of global GDP and contain 71 percent of the world's population and 73 percent of the world's poor. Moreover, expectations for long-term investment growth in EMDEs have been revised down significantly, partly because the slowdown in investment has been highly synchronous and protracted among these economies.

Recent investment weakness in EMDEs has followed the significant slowdown in investment growth in advanced economies (AEs) in the immediate aftermath of the global financial crisis. However, post-crisis investment weakness has different features in EMDEs than in AEs. In AEs, investment contracted sharply during the global financial crisis and, in the Euro Area, during the subsequent debt crisis. Investment in AEs recovered somewhat in 2014-16, but at a slower pace than in recoveries following earlier global downturns. In contrast, in EMDEs, investment continued growing through the global financial crisis and its immediate aftermath, but this expansion has slowed since 2010. World investment growth has also gradually lost steam over the past six years.

The slowdown in investment growth is occurring despite large unmet investment needs in many EMDEs. EMDEs' infrastructure, education, and health systems are struggling to keep pace with rapid urbanization, economic activity, and changing demands on workforces. Commodity-exporting EMDEs require investment to shift away from natural resource-based sectors toward other engines of growth. Vigorous private investment could give momentum to slowing productivity growth.

More generally, investment is critical to sustaining long-term growth. Capital accumulation raises labor productivity, a key driver of the long-term growth of real wages and household incomes, not only by capital-deepening-equipping workers with more capital-but often also by embodying productivityenhancing technological advances. While feeble investment in AEs has featured prominently in recent policy and academic debates, slowing investment growth in EMDEs has received less attention. ${ }^{3}$ Yet, EMDEs constituted about 45 percent of world investment and two-thirds of world investment growth during 2010-2015 (Figure 1).

This paper examines the recent weakness in EMDE investment, its underlying drivers, and possible policy responses to revive investment growth. In particular, it addresses the following questions. First, what are the main features of the investment slowdown? Second, what is the macroeconomic backdrop to slowing

\footnotetext{
${ }^{1}$ This paper draws from a background study featured in World Bank (2017). Figures and background data presented here are available at www.worldbank.org/gep.

${ }^{2}$ Throughout this paper, unless otherwise specified, investment refers to real gross fixed capital formation (public and private combined). For the sake of brevity, "investment" is understood to indicate investment levels. Investment growth is measured as the annual percent change in real investment. The long-term average refers to the average of available data for 1990-2008, the pre-crisis average to the average during 2003-08.

${ }^{3}$ Post-crisis investment weakness in advanced economies has been explored in Banerjee, Kearns, and Lombardi (2015); IMF (2015a); Leboeuf and Fay (2016); and Ollivaud, Guillmette, and Turner (2016).
} 
investment growth in EMDEs? Third, what are the factors associated with the investment slowdown, including spillovers from weak activity and investment in major economies? Fourth, what are the implications of weak investment growth for long-term growth prospects? Fifth, which policies can support investment?

The paper informs the debate on the recent slowdown in investment by making the following contributions. First, it focuses on EMDEs, whereas the bulk of the existing literature has focused on AEs. The few existing studies that analyze EMDE investment are either based on pre-crisis data or confine their analysis narrowly to the 2008-09 crisis or simply focus on specific regions. ${ }^{4}$ Second, it estimates the contributions of a comprehensive set of factors associated with weak investment growth. A number of empirical methods are used to zoom in on specific external and domestic factors. Third, it examines the implications of investment weakness in EMDEs for global trade, long-term prospects for growth and catchup, and it highlights the potential impact on productivity growth. Fourth, in light of its findings and insights from an extensive literature, the paper provides a wide range of macro- and microeconomic policy recommendations to revive investment growth.

The rest of the paper is organized as follows. Section 2 describes the main features of the investment slowdown. Section 3 explores the macroeconomic backdrop behind the slowdown. Section 4 examines the factors associated with the slowdown. Section 5 assesses the implications of weak investment for global trade, long-term growth, and income catch-up. Section 6 discusses policies to promote investment growth. Section 7 concludes.

\section{Main features of the investment slowdown}

During 2003-08, EMDE investment growth reached historic highs averaging 12 percent a year, more than twice the long-term average growth rate of 5 percent (Figure 2). The investment boom was particularly pronounced in commodity exporters, where soaring commodity prices encouraged investment in resource exploration and development and, in anticipation of higher future incomes, in non-resource projects (World Bank 2016a). Some of this elevated pre-crisis investment fueled activity in nontradables sectors (e.g., real estate) or in sectors whose growth prospects have dimmed considerably (e.g., mining). Since 2010, however, EMDE investment growth has slowed steadily from 10 percent in 2010 to 3.4 percent in 2015. By 2014, it was not only well below its double-digit pre-crisis average rates but also below its long-term average over 1990-2008.

The investment slowdown has been broad-based. It has been more sustained in EMDEs than in AEs and more pronounced than in periods following earlier global downturns. The slowdown has been visible in both private and public components of investment. Repeated downgrades to consensus forecasts for investment growth suggest a gradual recognition of its likely persistence.

Unusually weak. Investment growth remains more anemic - and its weakness has been more persistentthan in the aftermath of previous global recessions and slowdowns (Figure 3). From an unusually strong rebound in 2010, investment growth in EMDE commodity exporters has now slowed well below growth rates observed after previous global recessions and slowdowns.

\footnotetext{
${ }^{4}$ These include Anand and Tulin (2014); Caselli, Pagano, and Schivardi (2003); Qureshi, Diaz-Sanchez, and Varoudakis (2015); Bahal, Raissi, and Tulin (2015); and Cerra et al. (2016). Firm-level studies include Magud and Sosa (2015) and Li, Magud, and Valencia (2015).
} 
Broad-based. In 2015, investment growth was below its long-term average in more than 60 percent of EMDEs, the largest share over the past quarter-century outside serious global downturns (Figure 4). In the majority of EMDEs, investment growth has slowed in at least two out of three years during 2013-15.

Different between commodity exporters and importers. The slowdown in EMDE investment growth has been most pronounced among the BRICS and commodity-exporting economies. By 2015, investment growth had dropped to 3.7 percent in the BRICS and to 1.6 percent in non-BRICS commodity-exporting EMDEs from about 13 percent and 7 percent, respectively, in 2010. China accounted for about one-third of the investment growth slowdown in EMDEs between 2010 and 2015, and Brazil and Russia for another one-third.

In commodity exporters, investment weakness affected all types of investment (machinery and equipment as well as construction) and all sources of investment (public and private). Reflecting the divergence between commodity exporters and importers, the EMDE investment growth slowdown has been concentrated in EMDE regions with a large number of commodity-exporting economies. This includes Europe and Central Asia (ECA), where investment growth has been anemic from 2012-2015, Middle East and North Africa (MNA), and Latin America and the Caribbean (LAC), where investment has contracted in several large countries.

Although investment growth in commodity-importing EMDEs (excluding China and India) has been resilient as a group, this resilience has been mainly driven by a few large commodity importers. Among smaller commodity importers (those not part of the largest twenty EMDEs in nominal GDP terms), investment growth has stagnated over the post-crisis period.

Different from advanced economies. The sustained investment growth slowdown in EMDEs contrasts with the partial recovery in $A E$ investment growth since the global financial crisis. Investment growth in AEs averaged 2.1 percent over 2010-15. By 2014, it had reattained its long-term average growth rate, with investment growth not far below pre-crisis rates. The share of AEs investing below their long-term average rates declined from more than 80 percent in 2013 to about 60 percent in 2015.

Weak public and private investment. During 2010-15, private investment accounted for roughly 70 percent of total EMDE investment on average. The coordinated fiscal stimulus of 2008-09 lifted public investment growth above long-term averages in both AEs and EMDEs. In AEs, this boost was subsequently reversed. In EMDEs, public investment growth has remained positive but weaker during 2010-13 and, from 2014-15, dropped to below its long-term average, as discussed in detail later in the paper. Since the post-crisis rebound of 2010, private investment growth slowed in synch with public investment growth. In more than half of all EMDEs, private investment growth remained below the long-term average during 2010-15.

Expected to persist. EMDE investment growth has consistently fallen short of expectations (Figure 5). While 2010 consensus forecasts expected investment growth for EMDEs to reach 7 percent in 2015, the outturn was 0.9 percent. Both short-term forecasts and long-term expectations for investment growth in EMDEs have declined since 2010. This may partly reflect a recognition that the investment slowdown is returning growth to long-term average rates from record-high pre-crisis rates. However, the depth and reach of the weakness in investment suggest that the recent slowdown could be more than a simple reversion to the long-term trends. The downward revisions have been considerably more pronounced 
than those for real GDP growth. In AEs, long-term expectations about investment growth have been more steady, with a decline of just 1 percentage point over 2010-15.

\section{Macroeconomic backdrop}

Before delving into the main obstacles associated with the slowdown in investment in EMDEs, it is useful to consider the macroeconomic backdrop, shaped by a wide range of competing factors. Globally, borrowing costs have been at record lows and financial market liquidity has been ample since the financial crisis (Figure 6). In several EMDEs, domestic private credit to the nonfinancial private sector surged. However, multiple headwinds have offset the tailwinds to investment from historically low financing cost until late 2016. The headwinds have included disappointing activity and weak growth prospects, severe adverse terms of trade shocks for commodity exporters, easing and volatile capital flows, bouts of policy uncertainty in major economies, and rapid accumulation of private debt.

Weak activity. EMDE output growth has slowed sharply post-crisis, from 6.4 percent in 2011 to 3.5 percent in 2015, well below its pre-crisis average of 7 percent (Figure 6). To the extent that growth weakness is structural, investment weakness may be expected to persist (Didier et al. 2015). About onethird of the growth slowdown in EMDEs has been estimated to reflect structural causes. While the sources of the growth slowdown have varied across EMDEs, these have included a new era of lower commodity prices, spillovers from soft activity in major economies, weakening productivity growth, and a maturing of supply chains that has slowed global trade growth.

In major economies, activity has been soft post-crisis despite unprecedented monetary policy action. The Euro Area crisis was accompanied by a recession in 2012-13 that hurt trading partners, especially in Eastern Europe and North Africa. Euro Area growth prospects have continued to be subdued as crisis legacies have unwound. A series of one-off events, such as the debt ceiling debate in the U.S., caused disappointing growth outcomes. A secular decline in productivity growth has also reduced growth prospects in the United States. Growth in Japan has fluctuated around zero as a result of one-off events (e.g., major earthquakes in 2011 and 2016), earlier than expected policy tightening (VAT hike in 2014), long-term population pressures, and a slow pace of structural reforms. Weak growth prospects across advanced economies have raised the possibility of secular stagnation and a protracted period of extremely low long-run equilibrium interest rates that restrict monetary policy options (Summers 2014; Teulings and Baldwin 2014). In China, growth has slowed gradually towards more sustainable levels, with a rebalancing from manufacturing to services. This healthy transition has reduced commodity demand, with adverse spillovers to commodity-exporting EMDEs (World Bank 2016a).

Adverse terms of trade shocks. About two-thirds of EMDEs are reliant on exports of energy, metals, or agricultural commodities. Most commodity prices have fallen sharply from their early-2011 peaks-with metals and energy prices plunging by more than 40 percent (Figure 7). As a result, the terms of trade of commodity exporters have deteriorated by 4 percent since 2011, and those of oil exporters by 21 percent.

Subdued and volatile capital flows. FDI has been an important source of investment in EMDEs. FDI inflows to EMDEs have more than tripled since 2000 and accounted for about one-third of global FDI inflows in 2015. On average among EMDEs, gross FDI inflows amounted to 3 percent of GDP and 20 percent of domestic investment in 2015. Since 2010, however, growth in FDI inflows to EMDEs has slowed, partly as a result of weak activity in AEs (Figure 8). Non-FDI inflows have been more resilient-but notably volatilereflecting investors' search for yield amid low AE interest rates, with a shift away from bank flows to non- 
bank flows (McQuade and Schmitz 2016).

Heightened uncertainty. Political uncertainty has increased in many EMDEs since the 2008-09 global financial crisis (Figure 9). This has reflected geopolitical tensions in Eastern Europe, security challenges and conflicts in the Middle East, and acute domestic political tensions in several large EMDEs. Even in major AEs and EMDEs without significant political tensions, major policy shifts have often been accompanied by policy uncertainty. For example, bouts of policy uncertainty-e.g., government shutdowns and political stalemates in the United States, the Taper tantrum episode associated with the U.S. Federal Reserve Bank's policy plans, concerns around the future of the Euro Area during the Euro Area crisis, the U.K. referendum vote to leave the European Union (EU), and reforms related to financial markets and currency regime in China-have been a source of global financial market volatility further weighing on investor sentiment.

Rapid credit growth and debt overhang. On average, private credit in both commodity exporters and importers has increased by near 20 percentage points of GDP from 2000 to 2015 (Figure 10). The share of EMDEs with private credit-to-GDP ratios exceeding 60 percent had reached about one-fifth by 2015 , the highest share since 1990. Historically, during the three decades prior to the 2008-09 crisis, about 40 percent of all credit booms have overlapped with investment surges within one or two years. Credit booms since 2010, however, have been unusually "investment-less": virtually none of the post-crisis credit booms in EMDEs have been accompanied by investment surges. In several countries, rapid credit growth instead fueled above-average consumption growth. In the past, when such investment-less credit booms unwound, output contracted more than when the credit boom had been accompanied by an investment surge.

\section{Factors associated with the investment slowdown}

A series of econometric exercises is conducted to estimate the relative importance of these external and domestic factors to investment growth. First, in a panel regression, investment in 73 EMDEs and 26 AEs for 1998-2015 is modelled following the standard framework implying that the level of investment is chosen such that the marginal return on capital matches the risk-adjusted cost of capital. Specifically, the regression model includes as explanatory variables the proxies for the drivers of investment, including the marginal return to capital (e.g., output growth and terms of trade growth) and the risk-adjusted cost of capital (e.g., measures of uncertainty, FDI inflows, and the private credit-to-GDP ratio). ${ }^{5}$ These also are the factors that have shaped the macroeconomic backdrop as previously discussed.

Second, the analysis drills down into the short-term effects of uncertainty and weak activity in major advanced economies on EMDE investment growth using time-series methods. This is done in two sets of vector autoregressions tailored to examine each factor in detail. The need for quarterly data restricts the cross-country dimension of the sample (to 18 EMDEs) used in these exercises.

\footnotetext{
${ }^{5} \mathrm{~A}$ large cross-country dataset for investment growth is only available for aggregate gross fixed capital formation, which includes both private and public investment. The correlates of investment modelled here are mainly those relating to private investment whereas public investment is assumed to be mostly subject to discretionary policy decisions. In EMDEs, private investment on average constitutes about 70 percent of total investment. To mitigate concerns about endogeneity, output growth prospects are proxied by lagged output growth, in line with other studies (see Annex 1).
} 


\subsection{Medium-term correlates of EMDE investment growth}

Figure 11 summarizes the estimated effects of these variables on investment growth. Details of the panel regression model used to derive these results are presented in Annex 1 (Annex Tables 1.1 and 1.2). Whereas investment weakness in AEs has mainly reflected sluggish output (see G20 (2016a) and IMF (2015a)), investment weakness in EMDEs has been associated with a wider number of factors. While slowing output growth can account for three-quarters, on average, for slowdowns in investment growth among AEs during 2011-15, it accounted for a small share of the investment growth slowdown in the average EMDE. More important were terms-of-trade shocks (for oil exporters), and slowing FDI inflows (for commodity importers) as well as private debt burdens and political risk (for all groups of EMDEs).

In oil exporters, on average, the terms-of-trade shock caused by the oil price decline from 2014 onwards accounted for about one-half of the investment growth slowdown. In commodity importers, on average, slowing FDI inflows accounted for more than half of the slowdown in investment growth. Private sector debt-to-GDP ratios have had nonlinear effects on investment: with mounting private debt burdens, the beneficial effects of financial deepening on investment are increasingly outweighed by adverse effects of debt overhang (Appendix 1). ${ }^{6}$ The post-crisis deleveraging in some commodity-importing EMDEs has relieved some of the headwinds to investment growth. In contrast, in several non-energy commodity exporters, elevated private debt has weighed on investment. In some energy exporters with initially moderate post-crisis private debt stocks, a rapid buildup of private sector debt has increasingly held back investment growth. Rising political uncertainty may have accounted for about one-tenth of the slowdown in investment growth in commodity-importing and exporting EMDEs since 2011.

The actual investment growth slowdowns were considerably steeper than predicted by this econometric analysis. This suggests that there may be other, unobserved factors at work or that important nonlinearities have been present that have amplified the investment growth slowdown over time. The next two exercises consider some additional factors that could have been responsible for the slowdown in investment.

\subsection{Short-term impact of uncertainty on investment growth}

The annual measure of political risk used in the panel regression above is available for a large group of countries over an extended time period. For a considerably smaller group of countries and a shorter time window, two more granular quarterly measures of uncertainty are examined: uncertainty related to policies, as measured by the Economic Policy Uncertainty (EPU) index by Baker, Bloom, and Davis (2016), and uncertainty about financial market prospects (as proxied by stock market volatility).

The impact of these two variables on EMDE investment growth is estimated separately in a series of vector autoregression models for 18 EMDEs during 1998Q1-2016Q2 (Appendix 2). Details of the estimation are presented in Annex 2B. The results emphasize the importance of uncertainty in driving investment growth:

Global financial market uncertainty. The VIX index, which tracks the implied volatility of the U.S. S\&P 500 stock market price index, captures global financial market uncertainty as well as U.S. policy uncertainty.

\footnotetext{
${ }^{6}$ Credit to the private sector is used as a proxy for private sector debt. At 80 percent of GDP, an increase in private debt was associated with a one-third sharper decline in investment growth than a similarly sized increase in private debt from a starting point of 40 percent of GDP (See Appendix 1 and Annex 2A for details on the methodology).
} 
It is a key explanatory variable in driving EMDE investment, especially when there has been a sustained increase in the index. For example, a 10 percent increase in the VIX would considerably reduce EMDE investment growth (by about 0.6 percentage points within one year). This type of increase in uncertainty corresponds to about half of the five-day jump that was observed during heightened uncertainty about the health of the Chinese equity markets and capital outflows in August 2015, or the two-month rise at the height of the Euro Area crisis in September 2011.

Policy uncertainty in the European Union. Bouts of policy uncertainty in the EU, especially during the Euro Area crisis, had spillovers to close economic partners. For example, the Economic Policy Uncertainty Index for Europe doubled in June 2016 following the United Kingdom's vote to exit the EU or during the four months ending September 2011 (at the height of the Euro Area crisis). These uncertainties have reduced investment, especially in EMDEs in the ECA region.

Domestic policy uncertainty. A 10 percent increase in the EPU Index of domestic policy uncertainty in Brazil may have reduced investment growth by about 1 percentage point.

\subsection{Adverse spillovers from major economies}

Disappointing U.S. and Euro Area activity. U.S. and Euro Area growth has repeatedly disappointed expectations in recent years. Long-term consensus growth forecasts for the United States and the Euro Area have been revised downwards from 2.9 and 1.7 percent a year in 2010 to 2.3 and 1.4 percent a year in 2015, respectively-below pre-crisis estimates of potential growth. Weaker growth prospects in these two major economies, in turn, worsened EMDE growth prospects and reduced incentives for investment in their EMDE trading partners.

In 2015, the United States and the Euro Area accounted for 22 and 16 percent of global output, respectively, and for 11 percent and 25 percent, respectively, of global trade. Given the sheer size of these economies and their degree of trade and financial integration with the rest of the world, a slowdown in their growth significantly worsens growth prospects for EMDEs (World Bank 2016a).

To quantify growth spillovers from the United States and the Euro Area (which complements the previously described panel regression using annual data), Bayesian structural vector autoregressions were estimated for 1998Q1-2016Q2 for 18 EMDEs (excluding China, details of the model are presented in Annex 2C).

The main results suggest that a 1 percentage point decline in U.S. output growth reduces average EMDE output growth over the following year by about 0.8 percentage point (Figure 12). Perhaps in recognition of the possibility that U.S. adverse growth shocks are persistent, EMDE investment growth responded considerably more sharply to U.S. growth slowdowns than EMDE output growth. Furthermore, a 1 percentage point decline in Euro Area output growth lowered EMDE output growth by about 1.3 percentage points within a year. Again, EMDE investment growth responded almost twice as strongly (2.1 percentage points) than EMDE output growth. The somewhat larger estimated magnitude of spillovers from the Euro Area than from U.S. growth shocks may reflect the greater trade-intensity of Euro Area activity (Figure 12).

Policy driven slowdown in China. Sluggish economic activity in major AEs has coincided with a policydriven slowdown in output growth in China. This has been accompanied by a rebalancing from investment 
growth towards other, less trade-intensive sources of growth. As a result, China's investment growth has slowed gradually from record-high levels in the wake of the crisis (Appendix 3).

China is now the largest single trading partner for many EMDEs, especially in Sub-Saharan Africa. It accounted for virtually all of the increase in global metals demand and about half of the increase in global primary energy demand from 2010-14 (World Bank 2016a; Huidrom, Kose, and Ohnsorge forthcoming). As a result, China's output and investment slowdown has weighed on growth in other EMDEs.

To estimate the magnitude of the impact of China's output and investment slowdown on EMDE activity, a Bayesian vector autoregression is estimated for 1998Q1-2016Q2 for 18 EMDEs. A 1 percentage point decline in China's output growth is accompanied by about 0.5 percentage point slower output growth in other commodity-importing EMDEs and 1 percentage point slower output growth in commodityexporting EMDEs within a year. Since much of China's investment is resource-intensive, China's rebalancing away from investment has had an additional adverse impact on commodity-exporting EMDEs.

\section{Implications of weak investment for global trade, long-term growth and catch-up}

The post-crisis investment growth slowdown from record-high pre-crisis rates has lasting implications for global trade and long-term growth prospects. In many countries, investment is more import-intensive than other components of output. A slowdown in investment growth, therefore, weighs heavily on global trade growth. Moreover, by slowing the rate of capital accumulation and technological progress embedded in investment, a prolonged period of weak investment growth can set back potential output growth in EMDEs for years to come, with adverse implications for their ability to catch up with AE income levels.

Slower global trade. Since investment tends to be more import-intensive than other components of demand, investment weakness has been an important source of the post-crisis global trade slowdown (World Bank 2015b; IMF 2016; Constantinescu et al. 2016). This was reflected in weak import growth in capital goods (typically machinery and equipment), which accounted for about 14 percent of EMDE imports during 2015 (Figure 13). Capital goods imports tend to embody efficiency-enhancing technology transfers across borders (Alfaro and Hammel 2007). Hence, their slowdown may also be reflected in slowing EMDE productivity growth. Post-crisis global investment weakness was accompanied by a pullback in productive investment of multinational companies, which account for one-third of global trade. Capital expenditures (excluding mergers and acquisitions) by the 5,000 largest multinationals shrank in both 2014 and 2015 (UNCTAD 2016).

The global trade slowdown is not only a symptom, but also a transmission mechanism that propagates the slowdown in investment across countries (Freund 2016). Trade can facilitate more efficient allocation of capital goods and, thus, improve aggregate productivity which, in turn, would encourage investment (Mutreja, Ravikumar, and Sposi 2014).

Slower capital accumulation. Among OECD countries, the post-crisis slowdown in potential growth to a large extent reflects the slowing pace of capital deepening (Ollivaud, Guillemette, and Turner 2016; Hall 2016). Similarly, slowing capital accumulation weighs on potential growth in EMDEs. If investment growth is assumed to remain as low as in 2015 (3.3 percent), 2020 potential growth would be about two-thirds of potential growth in the pre-crisis investment growth scenario. 
Weaker productivity growth. In addition to slowing capital accumulation, weak investment growth is associated with slower total factor productivity growth, as investment is often critical to the adoption of new, productivity-enhancing technologies. ${ }^{7}$ Among AEs, a steady productivity growth slowdown was underway even before the global financial crisis. Possible drivers include structural change towards lowerproductivity services, caused partly by demand shifts related to population ageing, a lack of transformative innovations, and slower technology diffusion. ${ }^{8}$ Weaker investment growth may partly account for the slowdown in total factor productivity growth in EMDEs, from 2.2 percent in 2010 to -0.2 percent in 2015. ${ }^{9}$ The productivity slowdown was most pronounced in commodity-exporting EMDEs and those EMDEs with the slowest investment growth (Figure 14). Weaker total factor productivity growth would also be reflected in slower labor productivity growth-the key driver of long-term real wage growth and household income growth (Blanchard and Katz 1999; Feldstein 2008).

Slower income catch-up. Weak investment growth in EMDEs is both a symptom and a source of slowing pace of catch-up to AE income levels. Specifically, by reducing potential growth in EMDEs relative to AEs, it slows the pace of catch-up in per-capita incomes. In 2015, the difference in investment growth between EMDEs and AEs reached its lowest level since the early 2000s. If weakness in investment growth persists in EMDEs, per capita income catch-up to U.S. levels would require several generations. ${ }^{10}$ Since growth remains one of the most powerful drivers of poverty reduction, any setbacks to growth also imperil the achievement of global goals for poverty reduction (World Bank 2015d).

\section{Policies to promote investment growth}

The analysis in this paper suggests that both external and domestic factors are holding back investment in EMDEs. External factors include weak FDI inflows, low commodity prices, and bouts of global policy or political uncertainty. Domestic factors are overall weakness in economic activity and heightened domestic policy uncertainty. In the near-term, some of these drivers of investment growth are expected to turn more benign, but only very gradually. Investment growth is therefore expected to remain weak.

Yet many EMDEs have large unmet investment needs. First, a number of EMDEs are poorly equipped to keep pace with rapid urbanization, growing economic activity, and changing demands on workforce. Second, investment is also needed to smooth the transition away from growth driven by natural resources (in commodity exporters) or nontradables sectors (in some commodity importers) towards more sustainable sources of growth. Finally, a boost to private investment, especially, would help revive slowing productivity growth. The specific investment priorities differ across countries and regions. Robust policy action-even in countries with limited room to mobilize domestic resources-is needed to accelerate investment growth prospects.

\footnotetext{
${ }^{7}$ Gollop, Fraumeni, and Jorgenson (1987); Griliches (1988); Jorgenson (1991); Colecchia and Schreyer (2002); Bourreau, Cambini, and Dogan (2012); and OECD (2016a).

${ }^{8}$ Brynjolfsson and McAfee (2011); Cowen (2011); Gordon (2012); Bailey, Manyika, and Gupta (2013); McGowan and Andrews (2015); Andrews, Criscuolo, and Gal (2015); and OECD (2016a).

${ }^{9}$ TFP is calculated as residual from the growth-accounting framework in Didier et al. (2015). The slowdown happened despite some evidence of somewhat faster cross-country technology absorption from countries at the productivity frontier (Comin and Ferrer 2013; IFC 2016a).

${ }^{10}$ To the extent that weak investment growth is associated with weak TFP growth, slowing income catch-up can be further compounded, as TFP differences are a major source of differences in cross-country income per capita (Klenow and RodriguezClare 1997; Hall and Jones 1999; Caselli 2005; and Hsieh and Klenow 2010). An ageing population in many EMDEs, however, may be a force in supporting a higher capital level per person (Bussolo, Koettl, and Sinnott 2015).
} 
Although specific policy needs depend on country circumstances, in order to have a sustained improvement in investment growth prospects, it is necessary to employ a full range of available policiescounter-cyclical fiscal and monetary stimulus, as well as structural reforms. A two-pronged approach would simultaneously boost public and private investment. Fiscal policy measures could help by directly expanding public investment, while monetary policy could boost activity mainly through lowering the cost of financing for investment. Structural reforms could support investment by addressing the factors holding back private investment, including measures to improve aggregate growth and the business climate, as well as to reduce uncertainty.

\subsection{Fiscal policy}

Public investment accounted for 31 percent of total investment in EMDEs and 15 percent of total investment in AEs, on average, over the period 2010-15. In AEs, public investment growth has moved broadly counter-cyclically to private investment growth since 2008 (Figure 15). In EMDEs, the broad-based countercyclical surge in public investment in 2008-09 offset a significant slowdown in private investment growth. Post-crisis, this was followed by a period of easing public as well as private investment growth. In the majority of EMDEs, public and private investment growth have both been below their long-run averages since 2010 (Appendix 4).

Policymakers can use public investment in three ways to lift overall investment and output. First, public investment can raise domestic demand as part of fiscal stimulus. Second, a shift in government expenditures toward investment away from less efficient expenditures can make government operations more growth-friendly. Alternatively, revenues can be raised-preferably in ways that do not discourage investment - to finance public investment while containing fiscal deficits. Third, even within an existing envelope of public investment spending, spending efficiency can be improved to increase the benefits to growth from public investment.

Counter-cyclical fiscal stimulus. Growth prospects play a major role in investment decisions. To the extent that the EMDE growth slowdown since 2010 is cyclical, fiscal stimulus can help raise growth and investment where there is policy space (Didier et al. 2015). The current low-interest rate environment offers a rare opportunity to implement fiscal stimulus with limited impairment of long-term fiscal sustainability (Kose et al. forthcoming; OECD 2016c). Provided there is sufficient fiscal space and economic slack, and that measures are integrated into a credible medium-term fiscal framework, fiscal stimulus can support output growth (Huidrom, Kose, and Ohnsorge 2016).

In order to analyze the implications of expansion in public investment for activity and private investment, a vector autoregression model is estimated for eight EMDEs with available data, for 1998Q1-2016Q2. Details of the estimation are presented in Annex 2D. A 1 percent increase in public investment raises private investment about 0.26 percent above the baseline after just over a year (a temporary "crowdingin" effect). Thereafter, however, this positive effect dissipates and private investment returns toward the baseline (Figure 16).

Although the availability of cheap financing from global markets makes it relatively easier to undertake fiscal stimulus programs, most EMDEs have limited fiscal space for expansionary policy, given debt burdens and sizable deficits. In addition, cyclical policies for commodity exporters may be ineffective if they face persistent terms of trade shocks. 
Expenditure reallocation or revenue increases. Absent room for fiscal stimulus, spending on public investment can also be boosted by reallocating expenditures towards growth- enhancing investment at the expense of expenditures that are less clearly aligned with policy priorities. Such offsetting expenditure cuts could be identified in periodic Public Expenditure Reviews that assess all government expenditures against policy priorities (for example, World Bank 2015e; 2016c-d). Alternatively, domestic resources could be mobilized through increased revenue collection, whether by strengthening tax administrations, broadening tax bases, or raising tax rates. Revenue-to-GDP ratios are particularly low in South Asia and Sub-Saharan Africa (World Bank 2015b, 2016e). Even absent hikes in tax rates, efforts to remove exemptions, tighten tax administration, and broaden tax bases could yield revenue gains that could increase resources to finance public investment projects.

Expenditure efficiency. Even if the resource envelope for public investment cannot be increased, public investment can be turned more effective in reaching policy priorities by strengthening expenditure efficiency (Buffie et al. 2012). EMDEs in Sub-Saharan Africa and South Asia consistently score lowest among EMDE regions in indicators of efficiency of education and health care systems (Herrera and Pang 2005). Measures can be taken both on the revenue and the expenditure side to raise public spending efficiency. On the revenue side, output-based funding rules can strengthen incentives for ensuring greater efficiency. On the expenditure side, medium-term budget frameworks can improve spending predictability; greater transparency of expenditures and independent spending evaluations can improve incentives to tighten efficiency; and better coordination between different levels of government can reduce duplication and inconsistencies (Mandl, Dierx, and Ilzkovitz 2008; St. Aubyn et al. 2009). The disconnect between spending and asset accumulation of infrastructure services is particularly acute when governance and fiscal institutions are weak (Keefer and Knack 2007).

Expenditure efficiency has also been prioritized by G20 policymakers (G20 2015). Policy commitments among $\mathrm{G} 20$ countries include efforts to strengthen cost-benefit analyses and needs assessments, improve prioritization, increase the focus on investment quality, improve coordination of investment plans and reduce duplication, and increase transparency.

Addressing substantial investment needs. Regardless of the sources of financing, considerable investment is needed in all EMDE regions to meet the demands of rapid urbanization and growing activity, as well as to achieve the UNDP's Sustainable Development Goals. In total, such investment needs amount to about 1.9-3.1 percent of GDP per year during 2015-30, over and above the average EMDE investment of 24 percent of GDP during 2010-15 (UNCTAD 2014; Aschauer 1989; Fernald 1999; Czernich et al. 2011)). While specific investment priorities vary widely across regions, investments in infrastructure as well as in human capital, in particular health and education, foster long-term prospects for inclusive growth. ${ }^{11}$

Infrastructure investment. Infrastructure investment gaps are sizable (World Bank 2016b, Figure 18). ${ }^{12}$

\footnotetext{
${ }^{11}$ Where investment needs are large relative to public financial resources and institutions are robust, public investment can leverage private investment in public-private partnerships (PPP). Currently, the share of the private sector in infrastructure investment is 30-80 percent, depending on the industry, in developing countries (UNCTAD 2014). However, the share of the private sector in education and health investment in developing countries is modest at 15 and 20 percent, respectively. The challenges to designing effective PPPs are summarized in Bloomfield (2006) and Pongsiri (2002). The beneficial effects of public investment projects can be especially large when the economy's stock of infrastructure capital is relatively low (Calderon, MoralBenito, and Serven 2015).

${ }^{12}$ Even in OECD countries, sizable infrastructure gaps remain to maintain, improve, and expand energy, water, and transportation infrastructure (IEA 2014; OECD 2015 a,b).
} 
Investment in infrastructure not only raises investment directly, but can also crowd in private investment, under the right conditions. Crowding-in of private investment is more likely if public investment occurs amidst economic slack and accommodative financial conditions, if there are sizable infrastructure gaps impeding private investment, and if it is implemented in a strong institutional environment with sufficient trade and financial openness (Kessides 2004; Appendix 4).

Investment in public infrastructure can spark large benefits. In particular, it can encourage urbanization in EMDEs by expanding market access, improving the delivery of services, fostering innovation, or reducing transportation costs (Sokoloff 1988; Citigroup 2016). Urbanization, in turn, has been associated with higher growth of output as well as labor productivity (Glaeser 2008; World Bank 2009; Dasgupta, Lall, and Lozano-Gracia 2014). Infrastructure capital appears to be inversely correlated with income inequality among EMDEs, although the direction of causality remains a matter of debate (Ferreira 1995; Getachew 2010; Calderon and Serven 2014).

Health investment. Gaps in health investment relative to the levels needed to reach sustainable development goals remain substantial (UNCTAD 2014; Wagstaff, Bredenkamp, and Buisman 2014). Investment in health yields both microeconomic and macroeconomic benefits that are associated with aggregate gains in human welfare. Healthier individuals are more productive, better at creating and adapting to new technologies, and inclined to invest more in education (Aghion, Howitt, and Murtin 2011). They also have a longer life expectancy and are likely to save more, which feeds back into investment (Zhang et al. 2003). This relationship holds across and within countries and for numerous measures of health outcomes (Weil 2014). At the macroeconomic level, better health outcomes are associated with higher growth. ${ }^{13}$ By one estimate, a 1-year improvement in a population's life expectancy is associated with 4 percent higher output (Bloom, Canning, and Sevilla 2004).

Educational investment. Education investment gaps relative to the Sustainable Development Goals also remain sizable (UNCTAD 2014). Yet education investment that improves worker skills or reduces skill mismatches can raise worker incomes and productivity, as well as benefit firms. For individual workers, the average rate of return to another year of schooling is estimated to be a 10 percent increase in their lifetime labor market earnings (Montenegro and Patrinos 2014). For firms, a better match of worker skills to technological needs accelerates firms' pace of technology absorption and expansion (Winthrop et al. 2013). This is also reflected in the positive impact of education investment on growth in macro-level regressions. ${ }^{14}$

Clean energy investment. Progress in achieving the United Nation's Sustainable Energy for All Initiative objective remains slow (World Bank 2015f). Annual investment in clean energy is estimated to be about one-third of that required to achieve the initiative's goals. Yet clean energy technologies can generate more employment than traditional energy sources and energy-saving technologies can be productivityenhancing (Wei, Patadia, and Kammen 2010; Adhvaryu, Kala, and Nyshadham 2016).

\subsection{Monetary policy}

Like fiscal stimulus, monetary policy can boost growth and investment in a cyclical slowdown. The room to employ monetary policy in the short run varies significantly across emerging economies. Most

\footnotetext{
${ }^{13}$ World Bank (2007); Barro (2013); Baker et al. (2014); Barro and Lee (2015).

${ }^{14}$ By one estimate, 1 additional year of male upper-level schooling can raise growth by 1.2 percentage points per year (Barro 2013). Jones (2003) theoretically shows how educational attainment can be interpreted as an investment rate.
} 
commodity-exporting EMDEs have limited monetary policy space as inflation is already above target (Figure 17). A number of commodity-importing EMDEs (especially in Central and Southeastern Europe, and in South and East Asia) have below-target inflation and thus have some room to counteract shocks with further interest rate cuts. However, this room may narrow once monetary policy tightens in major advanced economies.

EMDEs typically have less developed financial systems than AEs, which limits the transmission of monetary policy. EMDE policymakers face a variety of challenges that differ significantly from those facing their counterparts in AEs: a susceptibility to rapid reversals in capital flows and the risks of contagion and fullblown financial crises; a limited influence on global markets combined with time-varying external credit constraints; generally limited ability to borrow internationally in domestic currency; the management of generally large international reserves; and higher degree of pass-through from exchange rate fluctuations to domestic prices (Chinn 2014; Mishra et al. 2014).

\subsection{Structural reforms}

The environment for EMDE investment growth is likely to remain challenging. AE growth is expected to remain subdued. Commodity prices are forecasted to rise only very gradually as excess supply, accumulated with strong pre-crisis investment in natural resources, is unwound slowly (World Bank 2016a). As monetary policy in AEs is expected to gradually normalize over the next few years, financing conditions could tighten and capital flows to EMDEs may ease. To offset these challenges, sustained improvements in the business climate and labor and product markets are needed to stimulate private investment.

Efforts to increase public investment are most effective in stimulating private investment and growth when implemented in a conducive business environment. Improvements in the business climate can both stimulate investment (domestic and FDI) and amplify the crowding-in effects of public and foreign direct investment-in addition to indirect benefits through higher growth, less informality, and more dynamic job creation (Didier et al. 2015). ${ }^{15}$ Business climate improvements include various areas. Lower startup costs are associated with higher profitability of incumbent firms, greater investment in information and communications technology, and more beneficial effects of FDI for domestic investment. Reforms to reduce trade barriers can encourage FDI and aggregate investment (Appendix 5). Corporate governance and financial sector reforms can improve the allocation of resources, including capital, across firms and sectors. Labor and product market reforms that increase firm profitability can encourage investment. Stronger property rights can encourage corporate and real estate investment. Improved access to power supplies can increase firm investment and productivity.

The panel regression aforementioned suggests that past major reform spurts in EMDEs have been associated with higher investment growth. This is also apparent in an event study of large spurts and setbacks in reforms among 97 EMDEs during 1996-2015 (Figure 19). In the period of the Great Moderation, about half of governance spurts occurred in commodity importers. Details of the approach are discussed in Annex 2E. Reform spurts were associated with significantly higher (by more than 4 percentage points) investment growth, on average, in the period of the reform.

\footnotetext{
${ }^{15}$ For the linkages between these reform measures and investment growth, see Reinikka and Svensson (2002); Field (2005); Wacziarg and Welch (2008); Schivardi and Viviano (2011); Munemo (2014); Corcoran and Gillanders (2015); Calcagnini, Ferrando, Giombini (2015); and Andrews, Criscuolo and Gal (2015).
} 
Progress in improving business climates has slowed in EMDEs since 2011. During the preceding six years, the cost of doing business, compliance times to meet regulations, and the number of regulatory procedures were cut considerably. On average, EMDEs move 6-10 percent closer to best practices in these dimensions. Since 2011, however, improvements have continued in EMDEs but, on average, at a slower pace (Figure 19). That said, some EMDEs, including China and a number of EMDEs in Europe and Central Asia, and Sub-Saharan Africa, have accelerated their improvements in business climates.

Policymakers in G20 countries have identified nine structural reform priorities. These include promoting trade and investment openness; advancing labor market reform, educational attainment, and skills; encouraging innovation; improving infrastructure; promoting fiscal reform; promoting competition and an enabling environment; improving and strengthening the financial system; enhancing environmental sustainability; and promoting inclusive growth (G20 2016b). Measures that particularly benefit investment include, for example, harmonizing cross-border regulations; easing or simplifying product market regulations; and leveling the playing field between private and state-owned enterprises (G20 2015). In addition, public investment is to be complemented by measures to strengthen private investment (e.g., promotion of participation of private investors in public-private partnerships).

Trade and integration agreements can demonstrate a binding commitment to reforms that will have the collateral benefit of improving the investment climate (Kose et al. 2009; Mody and Murshid 2005). Under an enhanced investment climate, stronger investment would also improve trade flows, as investment weakness has been a major driver of the recent slowdown in global trade. Regional trade agreements can help lower nontariff barriers and, thus, encourage FDI and deepen supply chain integration (World Bank 2016a; Petri and Plummer 2016). To be sustainable, these agreements need to be supported by measures to compensate vulnerable groups of society that could be adversely affected.

\section{Conclusions}

Relative to double-digit highs before the global financial crisis, investment growth in EMDEs has slowed considerably and steadily, from 10 percent in 2010 to 3.4 percent in 2015. The most pronounced slowdowns have taken place in BRICS and in commodity-exporting EMDEs. Investment growth is now below its long-term average in the largest number of EMDEs over the past quarter century, except during periods of serious global downturns. Long-term investment growth expectations have repeatedly been scaled back, possibly in recognition of considerably slower post-crisis output growth prospects, with knock-on effects on investment. The paper's main findings are as follows:

Factors associated with the slowdown. Whereas investment weakness in AEs mainly reflected anemic output growth, investment weakness in EMDEs has had a range of sources. In commodity importers, slowing FDI inflows and spillovers from soft activity in major advanced economies accounted for much of the slowdown in investment growth since 2011. In commodity exporters, a sharp deterioration in their terms of trade (for energy exporters), slowing growth in China, and mounting private debt burdens accounted for much of the slowdown in investment growth. In several EMDEs, political and policy uncertainty has been a key factor associated with investment contractions or slowdowns.

Spillovers. Over the past five years, AE growth has repeatedly fallen short of expectations partly because of crisis legacies. Sub-par growth and growth prospects in AE trading partners and source countries for FDI into EMDEs have slowed EMDE output growth. For every 1 percentage point lower output growth in the United States or Euro Area, EMDE output growth fell 0.8-1.3 percentage points within a year. Perhaps 
in recognition of prospects for a weaker external environment, EMDE investment growth responded about twice as strongly as EMDE output to declines in U.S. and Euro Area growth.

Sluggish economic activity in major AEs has coincided with a policy-driven slowdown in investment growth in China (Hong et al. 2016). This has contributed to weakening global commodity prices and has weighed on growth in other EMDEs through inter-sectoral input-output links and, indirectly, via output growth spillovers. A 1 percentage point decline in China's output growth is associated with a decline in output growth within a year of 0.5 percentage point (in commodity importers) to 1.0 percentage point (in commodity exporters). In addition to the overall output growth slowdown in China, a rebalancing of growth away from trade-intensive investment towards less trade-intensive sources of growth has generated adverse spillovers to other EMDEs, especially for commodity exporters.

"Investment-less" credit booms. Investment weakness has been set against the backdrop of exceptionally benign domestic (and global) financing conditions until late 2016. Policy interest rates of AE central banks are at or near record lows and, in several instances, negative (Arteta et al. 2016; World Bank 2016a). Private credit growth in about 30 EMDEs was near or above levels associated with credit booms at some point during 2010-15. Historically, around 40 percent of credit booms have coincided with investment surges. However, similar credit booms since 2010 have taken place with virtually no such investment surges but, instead, often with rapidly rising consumption.

Long-term implications of weak investment growth. By slowing capital accumulation and technological progress embedded in investment, weak post-crisis investment growth has contributed to lower potential output growth relative to pre-crisis rates. This slowdown in potential growth could be intensified if weakness in investment also sets back total factor productivity growth through a slowdown in embodied technological progress.

Policy responses. Policymakers can boost investment both directly, through public investment, and indirectly, by encouraging private investment, including foreign direct investment (FDI), and by undertaking measures to improve overall growth prospects and the business climate. Doing so directly through expanding public investment in infrastructure and human capital (especially education and health) would help raise demand in the short-run, increase potential output in the long-run and improve the environment for private investment and trade. Public investment would also help close investment gaps targeted by the United Nations Sustainable Development Goals, which have been estimated at up to 3 percent of global GDP per year.

More effective use of counter-cyclical fiscal and monetary policies can also promote private investment indirectly by strengthening output growth, especially in commodity-exporting EMDEs. These policies may be less effective, however, if employed to mitigate the impact of a persistent terms of trade shock. Also, there may be little scope for increased public investment or expansionary fiscal policy, if there is limited fiscal space. In any event, to raise investment growth sustainably, such policies will need to be buttressed by structural reforms to encourage both domestic private and foreign direct investment. Historically, reform waves in EMDEs have been associated with higher investment and output growth. Policy frameworks committed to reform, such as expansion of cross-border trade flows, can help lift investment by boosting confidence in growth prospects - not least via attracting FDI. 


\section{Annex 1. Determinants of investment: Empirical framework}

Framework. As in Hall and Jorgenson's (1967) seminal work, private investment is modelled as the level of private investment $I^{p}$ chosen such that the marginal return on capital (MPK) equals the cost of capital, which consists of the real interest rate $r$ and the rate of depreciation of capital $(\delta)$ :

$$
M P K=r+\delta
$$

As a result, private investment $I^{p}$ also depends on the determinants of the marginal product of capitalespecially total factor productivity TFP, the existing stock of private capital $K^{p}$, and the availability of complementary public capital $K^{g}$. In the presence of uncertainty, the cost of capital include a risk $\operatorname{premium} \pi$ :

$$
I^{p}=I^{p}\left(T F P, K^{g}, K^{p}, r, \pi, \delta\right)
$$

Higher cost of capital-whether due to higher risk premia or higher risk-free real interest rates-would reduce investment, whereas higher productivity and complementary public capital would raise it. In the data used in this study, the distinction between private and public capital is not available for a broad set of countries. Hence, the analysis is based on aggregate investment $I$, including both private and public investment.

$$
I=I(T F P, K, r, \pi, \delta)
$$

The investment growth regression employed in the paper includes explanatory variables as proxies for elements of this equation. The returns to capital (MPK) are proxied by output growth and terms of trade growth. The risk premium is proxied by measures of political uncertainty and financial market uncertainty. The cost of financing investment is proxied by FDI inflows, private credit, and the business climate.

These explanatory variables are also used in an extensive literature that has examined the determinants of investment growth. These include weak output growth, the terms-of-trade shocks caused by the slide in commodity prices since 2011, slow FDI flows, and intermittent bouts of political and policy uncertainty.

Weak output growth. The weakness in investment growth has coincided with weakness in output growth and a deteriorating growth outlook for EMDEs (Didier et al. 2015). The growth slowdown in EMDEs has reflected both structural factors and cyclical components. Weak growth prospects signal reduced opportunities for firms selling their goods and services and thus lead to lower investment. This is captured in the "accelerator model," which assumes that firms aim to maintain a constant capital-to-output ratio, in line with their expectations of future output growth (Jorgenson 1963; Jorgenson and Siebert 1968). Recent work on advanced economies has shown that output growth captures broad trends in investment, but actual investment often falls short of the model predictions. ${ }^{16}$ In the regression, weak growth prospects are proxied by lagged output growth to reduce concerns about endogeneity. ${ }^{17}$

\footnotetext{
${ }^{16}$ Lewis et al. (2014); Barkbu et al. (2015); Banerjee, Kearns, and Lombardi (2015); and Leboeuf and Fay (2016).

${ }^{17}$ Ideally, growth prospects would be captured by forecasts for several years ahead. However, these are highly endogenous to investment and highly correlated with FDI inflows. Alternatively, a truly exogenous source of output growth would be used, such as changes in public investment. However, the available panel data on public and private investment are sparse to conduct a panel regression. Some authors include measures of foreign demand into similar types of panel regressions. However, when included here, export growth is insignificant as its effect is captured by domestic output growth.
} 
Terms of trade movements. Sharp decreases in commodity prices have caused large post-crisis swings in terms of trade (Baffes et al. 2015). Terms of trade developments shape growth prospects for both commodity exporters and importers. In commodity-exporting economies, the terms of trade movements are dominated by commodity price fluctuations. Weaker terms of trade decreases return to investment, especially in commodity-related projects, and, by reducing firms' net worth, tighten their financial constraints.

Debt overhang. Elevated private debt may have an adverse impact on firms' investment for two reasons. First, since the benefits from investment are shared between the owner and the creditors of leveraged firms, high debt can discourage investment; and, second, high debt may reflect misallocation of capital to less innovative firms. This adverse effect is particularly pronounced for investment in an environment of weak growth prospects and in investment in long-lived assets, including real estate. ${ }^{18}$ The regression includes the lagged private sector credit-to-GDP ratio to proxy for household and firm debt burdens and the square of the lagged private sector credit-to-GDP ratio to capture the balance between beneficial effects of financial deepening and the adverse effects of debt overhang.

Reduced FDI inflows. FDI inflows can lift growth both by financing investment and by acting as catalyst for additional, domestically-financed investment. FDI may also have indirect, productivity-enhancing "collateral" benefits (Kose et al. 2009). These include pressures for better institutions, financial development, and more stabilizing macroeconomic policies. The absorption by domestic firms of the new technology, or managerial practices, introduced by FDI can stimulate domestic investment, provided financing is available. Forays into new export markets by domestic firms, encouraged by FDI, may require up-front investment. To fully harness the benefits of FDI for investment, however, a set of conducive initial conditions are necessary. These include a sufficiently skilled labor force that can readily adopt new technologies, a developed financial system that can readily finance productive new investment, sound institutions that facilitate firm startup and market entry and exit, and open trade regimes that encourage investment in industries with a comparative advantage. ${ }^{19}$ The regression includes the change in FDI inflows into the reporting economy (in percentage points of GDP) as a proxy for external financing sources of investment. ${ }^{20}$

Business climate and reforms. A number of studies have highlighted the importance of the institutional environment for investment. Post-crisis, private investment recovered faster in countries with more developed financial market infrastructure, and higher institutional quality (e.g., governance quality) has been associated with higher investment. ${ }^{21}$ To capture the business climate, a dummy variable is included for large reforms (two standard deviation improvements) captured in one of four governance indicators (regulatory quality, government effectiveness, rule of law, and control of corruption). The World Governance Indicators are typically highly persistent over time. Hence, much of their cross-country

\footnotetext{
${ }^{18}$ For arguments based on shared benefits from investment, see Myers (1977); Whited (1992); Occhino and Pescatori (2010); and Kalemli-Ozcan, Laeven and Moreno (2015). For misallocation arguments, see Lamont (2002); Hennessy (2004); Borio et al. (2015); Ollivaud, Guillemette and Turner (2016); and Melzer (forthcoming).

${ }^{19}$ Borensztein, Gregorio and Lee (1998); Bengoa and Sanchez-Robles (2003); Kohpaiboon (2003); Alfaro et al. (2004); Busse and Groizard (2008); Kose, et al. (2009); Azman-Saini, Law, and Ahmad (2010); and Azzimonti (2016).

${ }^{20}$ Ideally, non-FDI capital inflows would be included. However, this would reduce the sample size by one-third because of poor data availability pre-crisis.

${ }^{21}$ Mauro (1995); World Bank (2005); Everhart, Martinez-Vazquez and McNab (2009); Morrissey and Udomkerdmongkol (2012); Lim (2014); and Qureshi, Diaz-Sanchez, and Varoudakis (2015).
} 
variability is captured by the country fixed effects. Therefore, the regression analysis here focuses on periods in which there are large, statistically significant improvements (two standard deviations) in any two-year period. ${ }^{22}$

Policy uncertainty. When firms are uncertain about future demand and future policies, their expected riskadjusted returns may not exceed the costs of capital or the returns on liquid financial assets. This may make firms unwilling to commit to irreversible physical investment, a result found in a number of firmlevel studies on advanced economies. In macroeconomic studies, the uncertainty generated by political risk has been shown to weigh on investment (Appendix 2). ${ }^{23}$ The regression includes, as proxy for political stability, the International Country Risk Guide (ICRG) political stability rating. A higher index indicates greater political stability. The ICRG political risk index is a weighted average of ratings of government stability, socioeconomic conditions, investment profile, corruption, the role of military in politics, law and order, external and internal conflict, religious and ethnic tensions, democratic accountability, and bureaucratic quality.

Data. Data sources are drawn from Haver Analytics, World Bank's World Development Indicators, Oxford Economics, as well as the International Monetary Fund. Investment growth denotes the annual growth rate of real gross fixed capital formation. In instances where data on gross fixed capital formation are not available, gross capital formation is used as a proxy.

Methodology. A fixed effects panel regression is used to estimate the correlates of investment growth in 73 EMDEs with populations above 3 million for the period 1998-2015. The econometric framework is similar to that of Nabar and Joyce (2009). However, the focus in this paper is on investment growth, as a critical component of overall output growth (ultimately, the source of rising living standards), rather than changes in the investment-to-GDP ratio that would only capture changes in investment growth relative to output growth. This is in line with recent studies on advanced economies (Banerjee, Kearns and Lombardi 2015; Bussiere, Ferrara, and Milovic 2016; Barkbu et al. 2015; Kothari, Lewellen, and Warner 2015) or for individual EMDEs (Anand and Tulin 2014). The results are shown in Annex Table 1.1. The regressions control for sudden stops in capital inflows and for country-fixed effects. Since several sudden stops occurred during global recessions and slowdowns, they also capture the impact of these episodes.

Robustness. The choice of these explanatory variables is confirmed by a Bayesian Model Averaging approach (Annex Table 1.2). The results are broadly robust across subsamples, to the inclusion of event dummies such as for periods of large political risk events, and to the inclusion of five-year-ahead growth forecasts as additional explanatory variables. An alternative estimation technique, generalized method of moments, yields similar estimates. The results are also robust to the use of private investment growth (for a subset of countries and years) as the dependent variable. The analysis here employs a parsimonious specification to reduce collinearity between explanatory variables. However, the results are broadly robust to controlling for lagged public debt, squared lagged public debt, subcomponents of the ICRG index, and terms of trade volatility.

\footnotetext{
${ }^{22}$ A similar variable can be constructed for major reform setbacks. However, when a dummy variable for such setbacks is included in the regression the estimated coefficient is insignificant.

${ }^{23}$ Alesina and Perotti (1996); Bloom, Bond, and Van Reenen (2007); Gilchrist, Sim, and Zakrajsek (2014); Julio and Yook (2012); IFC (2016b).
} 
(1)

(2)

(3)

(4)

(5)

(6)

\begin{tabular}{|c|c|c|c|c|c|c|}
\hline VARIABLES & EMDE & $\begin{array}{c}\text { EMDE: } \\
\text { incl pol. } \\
\text { risk } \\
\text { events }\end{array}$ & GMM & $\begin{array}{c}\text { 5-year } \\
\text { ahead } \\
\text { forecasts }\end{array}$ & AE & $\begin{array}{c}\text { Private } \\
\text { Investment }\end{array}$ \\
\hline $\begin{array}{l}\text { Lagged Real GDP growth } \\
\text { (percent) }\end{array}$ & $\begin{array}{c}0.429 * * \\
{[0.163]}\end{array}$ & $\begin{array}{l}0.415^{* *} \\
{[0.164]}\end{array}$ & $\begin{array}{c}0.441 * * * \\
{[0.168]}\end{array}$ & $\begin{array}{c}1.717 \\
{[1.219]}\end{array}$ & $\begin{array}{c}0.829 * * * \\
{[0.157]}\end{array}$ & $\begin{array}{l}0.381 * * \\
{[0.186]}\end{array}$ \\
\hline $\begin{array}{l}\text { Change in FDI inflows } \\
\text { (percentage points of GDP) }\end{array}$ & $\begin{array}{l}0.605^{* *} \\
{[0.269]}\end{array}$ & $\begin{array}{l}0.602 * * \\
{[0.271]}\end{array}$ & $\begin{array}{c}0.468 * * \\
{[0.232]}\end{array}$ & $\begin{array}{c}0.179 \\
{[0.158]}\end{array}$ & $\begin{array}{c}0.145^{* * *} \\
{[0.049]}\end{array}$ & $\begin{array}{c}0.997 * * * \\
{[0.342]}\end{array}$ \\
\hline Political stability & $\begin{array}{c}0.473 * * * \\
{[0.138]}\end{array}$ & $\begin{array}{c}0.405^{* * *} \\
{[0.140]}\end{array}$ & $\begin{array}{l}0.297 * * \\
{[0.145]}\end{array}$ & $\begin{array}{c}0.602 * * * \\
{[0.172]}\end{array}$ & $\begin{array}{c}0.017 \\
{[0.116]}\end{array}$ & $\begin{array}{c}0.509 * * * \\
{[0.181]}\end{array}$ \\
\hline $\begin{array}{l}\text { Lagged credit to GDP ratio } \\
\text { (percent of GDP) }\end{array}$ & $\begin{array}{l}-0.095 \\
{[0.072]}\end{array}$ & $\begin{array}{l}-0.126^{*} \\
{[0.074]}\end{array}$ & $\begin{array}{c}-0.217^{* *} \\
{[0.098]}\end{array}$ & $\begin{array}{l}-0.092 \\
{[0.096]}\end{array}$ & $\begin{array}{l}-0.029 \\
{[0.053]}\end{array}$ & $\begin{array}{c}0.018 \\
{[0.079]}\end{array}$ \\
\hline $\begin{array}{l}\text { Lagged credit to GDP ratio, } \\
\text { squared }\end{array}$ & $\begin{array}{c}-0.001^{* *} \\
{[0.000]}\end{array}$ & $\begin{array}{l}-0.001 * \\
{[0.001]}\end{array}$ & $\begin{array}{c}0.001 \\
{[0.001]}\end{array}$ & $\begin{array}{c}-0.002 * * * \\
{[0.000]}\end{array}$ & $\begin{array}{c}-10 \mathrm{e}^{-5} \\
{[0.000]}\end{array}$ & $\begin{array}{c}-0.002^{* * *} \\
{[0.000]}\end{array}$ \\
\hline Terms of trade growth (percent) & $\begin{array}{c}0.131^{* * *} \\
{[0.037]}\end{array}$ & $\begin{array}{c}0.132 * * * \\
{[0.035]}\end{array}$ & $\begin{array}{c}0.133 * * * \\
{[0.032]}\end{array}$ & $\begin{array}{c}0.277^{* * *} \\
{[0.069]}\end{array}$ & $\begin{array}{c}0.026 \\
{[0.119]}\end{array}$ & $\begin{array}{c}-0.093 \\
{[0.061]}\end{array}$ \\
\hline Large reform spurt & $\begin{array}{l}4.503 * * \\
{[2.223]}\end{array}$ & $\begin{array}{l}4.266^{*} \\
{[2.232]}\end{array}$ & $\begin{array}{l}2.862 * \\
{[1.727]}\end{array}$ & $\begin{array}{c}3.607 \\
{[3.232]}\end{array}$ & $\begin{array}{l}-0.149 \\
{[1.028]}\end{array}$ & $\begin{array}{l}6.831^{*} \\
{[3.744]}\end{array}$ \\
\hline $\begin{array}{l}\text { Large deterioration in political } \\
\text { stability }\end{array}$ & & $\begin{array}{l}-3.854^{* *} \\
{[1.526]}\end{array}$ & & & & \\
\hline Sudden stop dummy & $\begin{array}{c}-4.094 * * * \\
{[1.544]}\end{array}$ & $\begin{array}{c}-4.059 * * \\
{[1.544]}\end{array}$ & $\begin{array}{c}-5.381^{* * *} \\
{[1.220]}\end{array}$ & $\begin{array}{c}-7.495^{* *} \\
{[2.664]}\end{array}$ & $\begin{array}{c}-4.543^{* * *} \\
{[0.901]}\end{array}$ & $\begin{array}{c}-7.151^{* * *} \\
{[1.703]}\end{array}$ \\
\hline Constant & $\begin{array}{c}-19.315^{* *} \\
{[9.450]}\end{array}$ & $\begin{array}{l}-13.811 \\
{[9.585]}\end{array}$ & $\begin{array}{c}-7.974 \\
{[8.822]}\end{array}$ & $\begin{array}{c}-33.95 * * * \\
{[9.765]}\end{array}$ & $\begin{array}{c}3.162 \\
{[9.781]}\end{array}$ & $\begin{array}{l}-22.974 * \\
{[11.804]}\end{array}$ \\
\hline Observations & 1,098 & 1,092 & 1,098 & 327 & 411 & 809 \\
\hline R-squared & 0.126 & 0.136 & & 0.270 & 0.272 & 0.128 \\
\hline Number of countries & 73 & 73 & 73 & 20 & 26 & 59 \\
\hline
\end{tabular}

Note: Results of a panel regression with country fixed effects for 73 EMDEs during 1998-2015. Column (1) denotes the baseline regression. All coefficient estimates (except that for the squared credit-to-GDP ratio) are expected to be positive; the coefficient estimate for the squared credit-to-GDP ratio is expected to be negative. Column 2 controls for episodes of large deterioration in political stability, as defined by two standard deviation below the historical mean. GMM stands for generalized methods of moments. Column 4 replaces five-year ahead forecasts for lagged growth. AE stands for advanced economies. For the GMM regression in Column (3), the Wald chi square statistic is 84.25 . Column (6) replaces dependent variable with private investment growth. Robust standard errors in brackets. ${ }^{* * *} p<0.01,{ }^{* *} p<0.05,{ }^{*} p<0.1$ 
Annex Table 1.2. Bayesian Model Averaging

\begin{tabular}{lc}
\hline Dependent variable: Investment growth & $(1)$ \\
VARIABLES & \\
\hline & 0.558 \\
Lagged real GDP growth (percent) & {$[1.00]$} \\
& 0.703 \\
Change in FDI inflows (percentage points of GDP) & {$[1.00]$} \\
& 0.126 \\
Political stability & {$[0.83]$} \\
& -0.067 \\
Lagged credit to GDP ratio (percent of GDP) & {$[0.81]$} \\
& 0.154 \\
Terms of trade growth (percent) & {$[0.99]$} \\
& 3.017 \\
Large reform spurt & {$[0.53]$} \\
Sudden stop dummy & -3.777 \\
& {$[0.84]$} \\
Constant & -1.116 \\
& {$[1.00]$} \\
Observations & \\
\hline
\end{tabular}

Note: Estimation results are based on Bayesian model averaging. The sample is the same as in Annex Table 1.1. Probability of inclusion of each variable are in brackets.

\section{Annex 2. Definitions and methodology}

A. Investment-less credit booms. Data for the broadest definition of credit are provided by the Bank for International Settlements for 14 EMDEs from 1980 to 2015 (Argentina, Brazil, China, Hungary, India, Indonesia, Malaysia, Mexico, Poland, Russia, Saudi Arabia, South Africa, Thailand, and Turkey).

For other EMDEs, where credit from the domestic banking system remains the main source of credit (Ohnsorge and Yu 2016), annual data on claims by banks on the private sector, provided by the IMF's International Financial Statistics, are used as proxies for credit to the nonfinancial private sector. This broadens the sample by another 41 countries, mainly from 2000 onwards. These include Azerbaijan, Bahrain, Bangladesh, Bulgaria, Bolivia, Botswana, Colombia, Chile, Costa Rica, Cote d'Ivoire, Croatia, Egypt, Gabon, Georgia, Ghana, Guatemala, Honduras, Jamaica, Jordan, Kazakhstan, Kenya, Kuwait, Mauritius, Mongolia, Namibia, Nigeria, Oman, Pakistan, Philippines, Panama, Paraguay, Peru, Qatar, Senegal, Serbia, Tunisia, Sri Lanka, Ukraine, Uruguay, República Bolivariana de Venezuela, and Zambia.

Advanced economies (AEs) included in the sample are Australia; Austria; Belgium; Canada; Denmark; Finland; France; Germany; Greece; Hong Kong SAR, China; Ireland; Israel; Italy; Japan; Republic of Korea; Luxembourg; Netherlands; New Zealand; Norway; Portugal; Singapore; Spain; Sweden; Switzerland; United Kingdom; and United States. 
B. Implications of rising uncertainty on investment in EMDEs. To assess the role of uncertainty for EMDE investment during 1998Q1-2016Q2, aggregate vector autoregressive models for 18 EMDEs are applied. Given limited data availability, the sample varies for each indicator of uncertainty. Therefore, a series of separate vector autoregressive models are estimated. The results are statistically significant within the usual 16-84 percent confidence bands.

The sample includes 18 EMDEs with available data for key quarterly macroeconomic indicators and stock market indexes: Brazil, Bulgaria, Chile, Costa Rica, Hungary, India, Indonesia, Malaysia, Mexico, Paraguay, Peru, Philippines, Poland, Romania, Russia, South Africa, Thailand, and Turkey. The literature on uncertainty often uses the option-induced volatility measure VXO (e.g., Bloom 2009) or rich monthly macro-data (279 macro and financial series in the case of Jurado, Ludvigson, and $\mathrm{Ng} 2015$ ) to construct uncertainty measures. However, for many EMDEs, such measures cannot be constructed.

There are two sources of uncertainty: domestic and global. Global uncertainty is captured by financial market and policy uncertainty in the United States and the European Union (EU). Financial market uncertainty is proxied by the VIX for the United States and by the standard deviation of daily stock price changes for the Euro Area. Policy uncertainty is captured by the Economy Policy Uncertainty Index for the United States and the EU. Domestic financial market uncertainty is proxied by the standard deviation of daily stock market changes; domestic policy uncertainty is proxied by the ICRG index of political risk or, for Brazil, the Economic Policy Uncertainty Index.

Global uncertainty. Vector autoregressions are used to estimate the impact of global uncertainty on EMDE investment. The data consist of investment-weighted averages for 18 EMDEs for 1998Q1-2016Q2. Endogenous variables follow this Cholesky ordering: global financial market or policy uncertainty, EMDE stock price index; EMDE bond price index, and aggregate real output and investment in EMDEs. Exogenous regressors, included with two lags, are: G7 real GDP growth, world stock price index, and U.S. 10-year bond yields. For the estimation of the impact of EU uncertainty (as measured by the EPU), the sample includes EMDEs in Europe and Central Asia (Bulgaria, Hungary, Poland, Romania, Russia, Turkey). ${ }^{24}$ The results are statistically significant within the usual 16-84 percent confidence bands.

Domestic uncertainty. Country-specific vector autoregressions are used to estimate the impact of domestic uncertainty on EMDE investment growth. The sample includes data for the same $18 \mathrm{EMDEs}$ as listed above for 1998Q1-2016Q2. The variables include, in this Cholesky ordering: global financial market uncertainty, domestic financial market or political uncertainty, domestic stock prices, short-term interest rates, and domestic real investment. G7 real GDP growth is included as an exogenous regressor to preserve degrees of freedom. The regression is estimated with two lags. The model is adapted from the Bloom (2009) U.S. model, with these changes: employment is dropped due to data constraints, global uncertainty measures are added, and quarterly data replaces monthly data. For the full sample of emerging market and developing economies, on average, the impact of domestic uncertainty-whether financial or political in nature-is insignificant throughout the forecast horizon. These results are not reported in the text. Data for the International Country Risk Guide variables are quite smooth; a shortterm quarterly vector autoregression model therefore struggles to identify any significant correlations. Economic Policy Uncertainty data show more variance for the Brazilian economy; in these cases, the

\footnotetext{
${ }^{24} \mathrm{~A}$ similar estimation for other EMDEs yielded insignificant results, likely reflecting weaker trade and financial links with the EU.
} 
estimated impact of domestic uncertainty (as measured by the EPU) on domestic investment is highly significant.

C. Spillovers from the United States, the Euro Area, and China. In order to quantify spillovers from an output slowdown in the United States and the Euro Area, a Bayesian structural vector autoregression is estimated for 1998Q1-2016Q2, using weighted average data for 18 EMDEs. The sample includes Brazil, Bulgaria, Chile, Costa Rica, Hungary, India, Indonesia, Malaysia, Mexico, Paraguay, Peru, Philippines, Poland, Romania, Russia, South Africa, Thailand and Turkey. The regression includes, in this Cholesky ordering: weighted average output growth in major advanced economies and China (excluding either the United States or the Euro Area), U.S. or Euro Area output growth, proxies for global financial conditions (U.S. 10-year sovereign bond yield and JP Morgan's EMBI index), and aggregate output growth or investment growth in EMDEs (excluding China). To conserve degrees of freedom, oil price growth is included as an exogenous regressor in the model. A similar estimation is applied to estimate the impact of a slowdown in China's output or investment growth on EMDE output growth. The regression includes, in this Cholesky ordering: weighted average output growth in major advanced economies, proxies for global financial conditions (U.S. 10-year sovereign bond yield and JP Morgan's EMBI index), China's output growth or China's non-investment growth and China's investment growth, and output growth in EMDEs (excluding China). The oil price is again included as exogenous regressor.

D. Crowding-in of private investment by public investment. A vector autoregression is conducted to estimate crowding-in of private investment by public investment for eight EMDEs with available data for 1998Q1-2016Q2. A decomposition of investment into private and public investment is only available for a restricted sample of EMDEs. The sample includes Bulgaria, Czech Republic, Hungary, Mexico, Poland, Romania, Slovak Republic, and Turkey. These countries are highly open and rank above the EMDE average in the World Bank Doing Business indicators. Variables included are, in this ordering: real government investment, real GDP, real private investment, current account balance, and the real effective exchange rate. The results are statistically significant within the usual 16-84 percent confidence bands.

E. Investment growth and reforms. Values in columns of Figure 19 are based on a panel data regression in which the dependent variable is real investment growth. A spurt (setback) is defined as a two-year increase (decrease) by two standard deviations in one or more of the following four measures of the Worldwide Governance Index (WGI): regulatory quality, government effectiveness, rule of law, and control of corruption. The WGI indicators are principal components of a wide range of survey based and other indicators. For each index, the standard deviation is measured as the average of the standard errors of the WGI Index in the beginning and at the end of each two-year interval. Episodes in which there were improvements in one measure and simultaneous setbacks in another are excluded. The sample spans 97 EMDEs over 1996 - 2015, and excludes EMDEs with populations less than 3 million.

Let $t$ denote the end of a two-year spurt or setback. The coefficients are dummy variables for spurts and setbacks over the $[t-3, t+2]$ window around these episodes. In Figure 19, "Reform" denotes the $t=[-1,0]$ window (i.e., around the two years of improvement/deterioration). All coefficients show the investment growth differential of economies during an episode compared to those that experienced neither improvements nor setbacks. All estimates include time-fixed effects to control for global common shocks and country-fixed effects to control for time - invariant heterogeneity at the country - level. Robust standard error estimates during the reform spurt window are jointly significant at the ten percent level (Annex Table 2.1). 
Annex Table 2.1. Investment growth around governance reform spurts and setbacks

\begin{tabular}{|c|c|}
\hline $\begin{array}{l}\text { Dependent variable: } \\
\text { investment growth }\end{array}$ & \\
\hline $\mathrm{t}-3$ & -1.52 \\
\hline & (2.74) \\
\hline $\mathrm{t}-2$ & -2.67 \\
\hline & (2.37) \\
\hline $\mathrm{t}-1$ & 0.84 \\
\hline & $(2.69)$ \\
\hline Period t of reform spurt & $4.58^{* *}$ \\
\hline & $(2.01)$ \\
\hline $\mathrm{t}+1$ & 2.32 \\
\hline & $(2.37)$ \\
\hline $\mathrm{t}+2$ & -0.46 \\
\hline & (2.96) \\
\hline$s-3$ & -2.33 \\
\hline & (3.58) \\
\hline $\mathrm{s}-2$ & -1.05 \\
\hline & $(2.18)$ \\
\hline $\mathrm{s}-1$ & -1.81 \\
\hline & $(2.86)$ \\
\hline Period s of reform setback & -2.17 \\
\hline & $(2.56)$ \\
\hline $\mathrm{s}+1$ & -2.02 \\
\hline & $(2.83)$ \\
\hline $\mathrm{s}+2$ & -0.78 \\
\hline & (2.97) \\
\hline Observations & 1,582 \\
\hline R-squared & 0.127 \\
\hline
\end{tabular}

Note: The regression includes time and country fixed effects. $t$ indicates the period of the significant reform spurt, $\mathrm{s}$ the period of the significant reform setback as defined in Annex 2E. Robust standard errors in parentheses. ${ }^{* * *} \mathrm{p}<0.01,{ }^{* *} \mathrm{p}<0.05,{ }^{*} \mathrm{p}<0.1$ 
Figure 1. Investment growth slowdown

Investment growth in EMDEs has slowed sharply since the global financial crisis. In 2015, the share of EMDEs with investment growth below its long-term average reached its highest level excepting global downturns. Long-term forecasts suggest continued weakness in investment growth. The investment growth differential between EMDEs and AEs has narrowed.

\section{A. Investment growth}

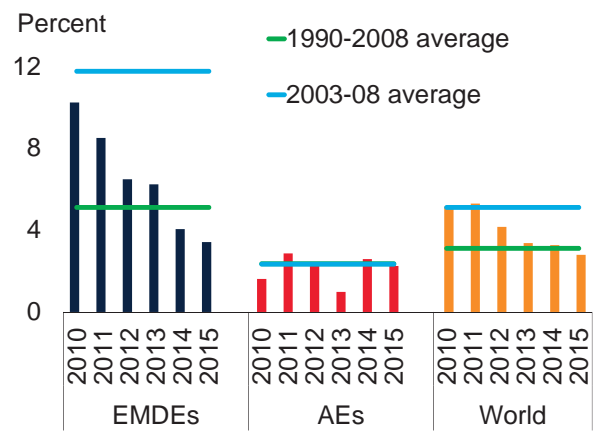

C. Catch-up to U.S. per capita incomes

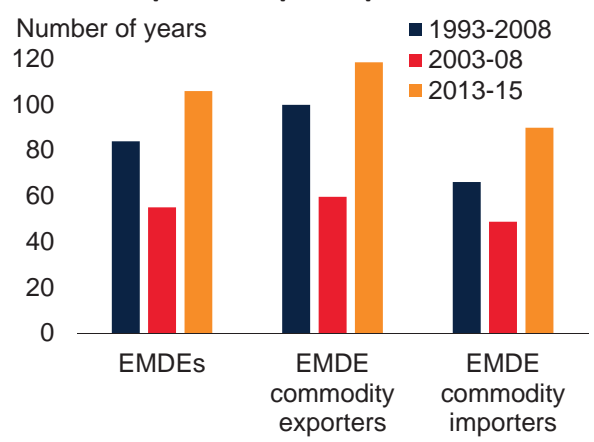

E. Difference between AE and EMDE investment growth

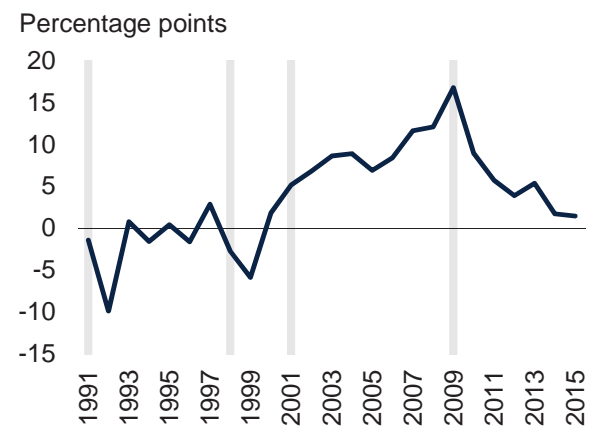

$B$. Share of EMDEs with investment growth below its longterm average

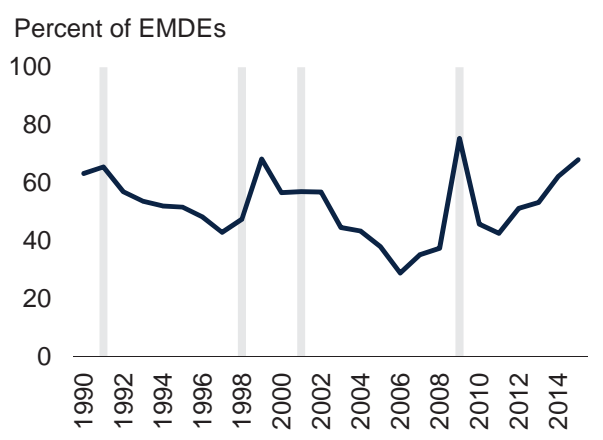

D. Five-year-ahead forecasts of investment growth

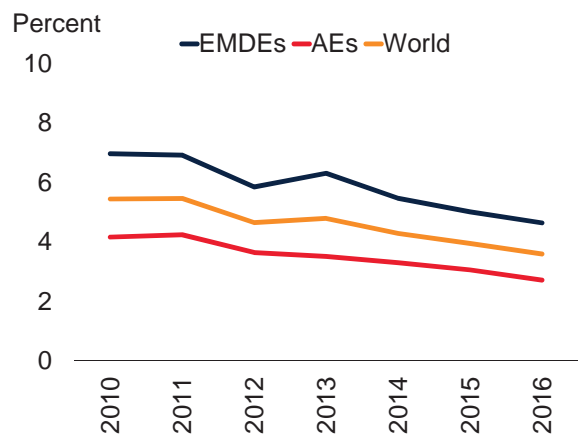

\section{F. Share of world investment}

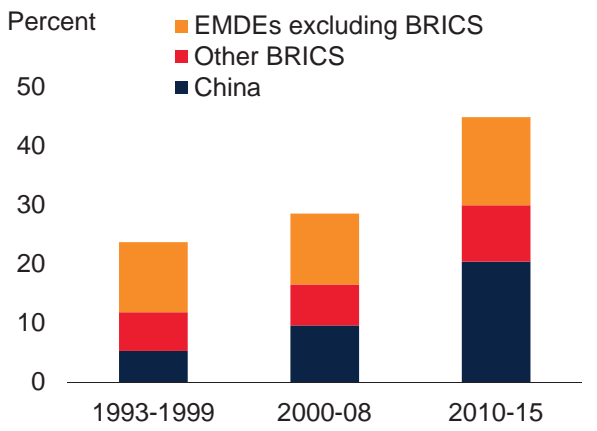

Sources: Consensus Economics; Haver Analytics; International Monetary Fund; Oxford Economics; World Development Indicators, World Bank.

A. Weighted averages. Long-term average starts in 1991 for EMDEs due to lack of earlier data.

B. Long-term averages are country-specific and refer to 1990-2008. Latest year is 2015.

C. Number of years needed to catch-up with 2015 real per capita GDP level in the United States, assuming average growth rates over each period denoted for each group.

D. Each line shows five-year-ahead Consensus Forecasts as of the latest available month in the year denoted. Unweighted averages of $21 \mathrm{EMDEs}$ and 25 advanced economies. World sample includes 46 countries. Last observation is for October 2016. E. The sample includes 100 EMDEs and 34 AEs. Difference between EMDEs' and AEs' weighted average investment growth rates.

F. Each column shows the period average of the share of global investment contributed by each respective group denoted. The world sample includes 100 EMDEs and 34 AEs. 
Figure 2. Investment growth slowdown: Group-specific and regional dimensions

The slowdown in EMDE investment growth has been pronounced and persistent among BRICS, commodity exporters, and many commodity importers. It has been concentrated in EMDE regions with predominantly commodity-exporting countries, in Europe and Central Asia, Latin America and Caribbean, and Middle East and North Africa.
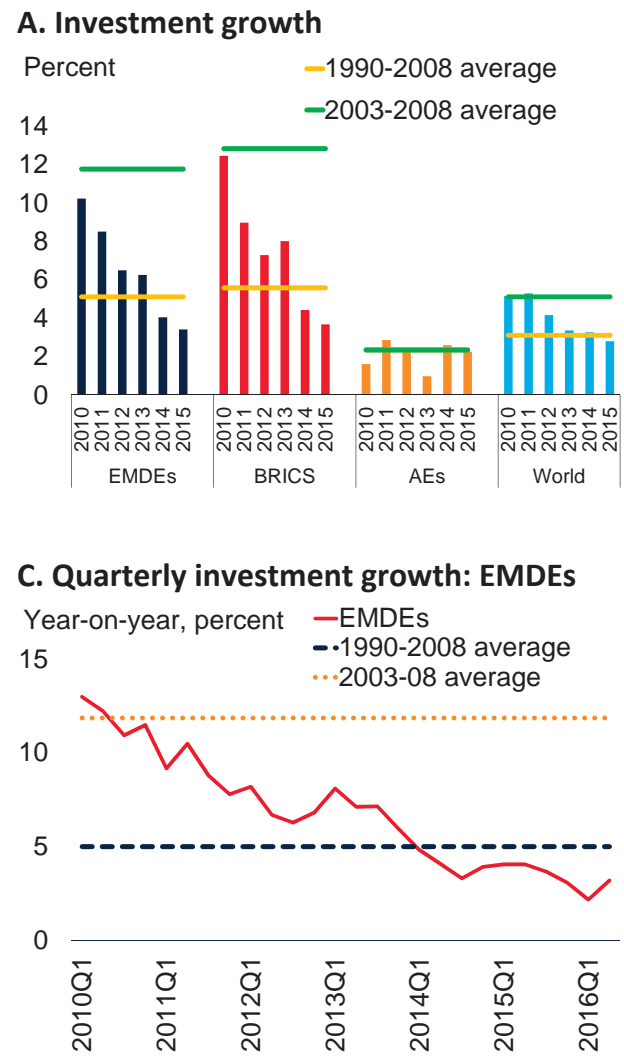

E. Regional dimensions

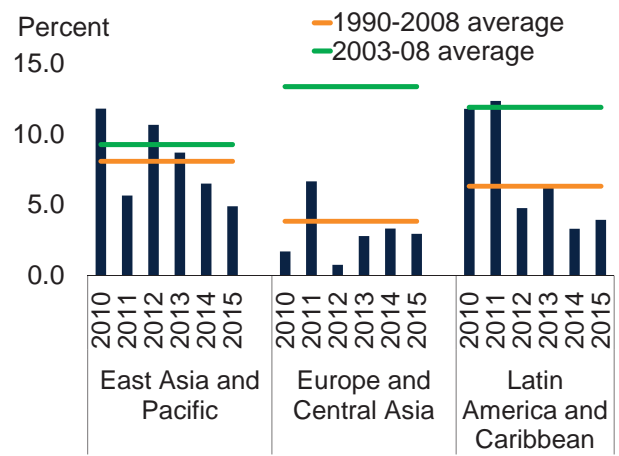

B. Investment growth (cont.)

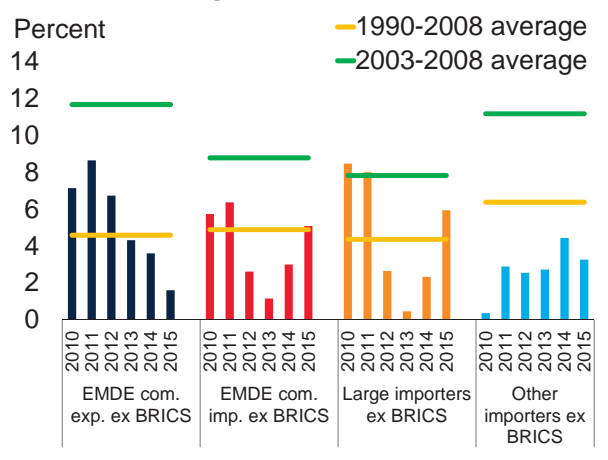

D. Contributions to EMDE investment growth

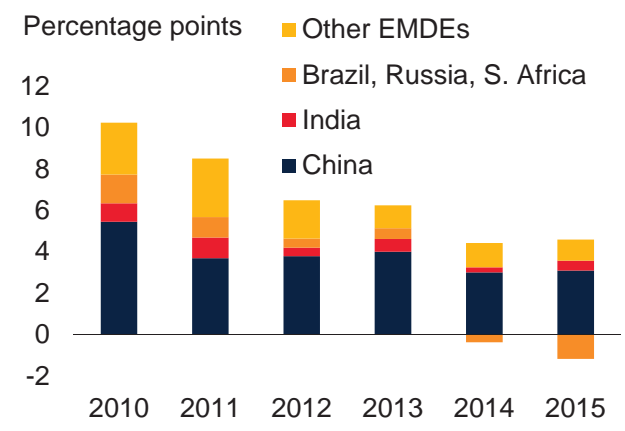

F. Regional dimensions (cont.)

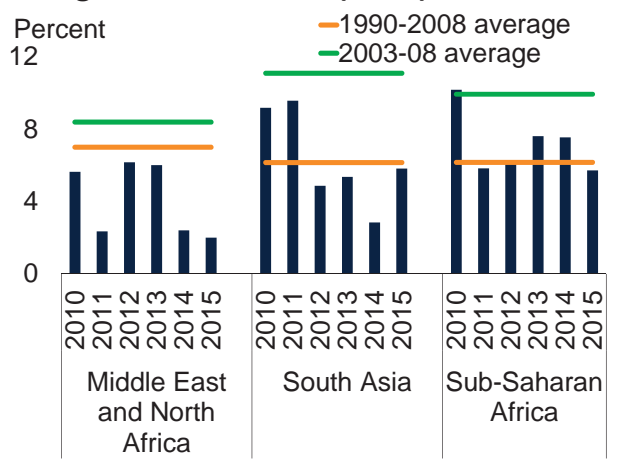

Sources: Haver Analytics; International Monetary Fund; Oxford Economics; World Development Indicators, World Bank.

A.B. Weighted averages. Long-term average starts in 1991 for EMDEs due to lack of earlier data. The EMDE sample includes 126 economies. "ex BRICS" excludes BRICS economies within each group. Large importers refer to the seven EMDE commodity importers ranked in the top 20 EMDEs (ex BRICS) in nominal GDP terms. Other importers include 42 economies.

C. Weighted averages. Includes 28 EMDEs with available quarterly data. Long-term averages start in 1991 for EMDEs and are based on annual data. Last observation is for Q2 2016.

D. Percentage point contribution by each country group to EMDE investment growth.

E.F. Medians across EMDEs of each region to ensure broad-based representation. Long-term averages are period averages of annual medians. East Asia and Pacific, Europe and Central Asia, Latin America and Caribbean, Middle East and North Africa, South Asia, and Sub-Saharan Africa include 8, 12, 18, 10, 5, and 26 economies, respectively. 


\section{Figure 3. Investment growth after global downturns}

After an unusually strong rebound in 2010, investment growth in EMDE commodity exporters in 2014-15 slowed well below the average growth rates after previous global downturns. In EMDE commodity importers, investment growth has been consistently more anemic than after previous global downturns.

\section{A. Advanced economies}

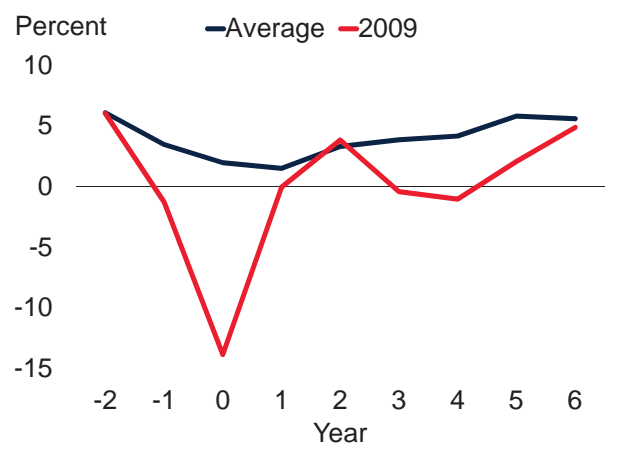

\section{EMDE commodity importers}

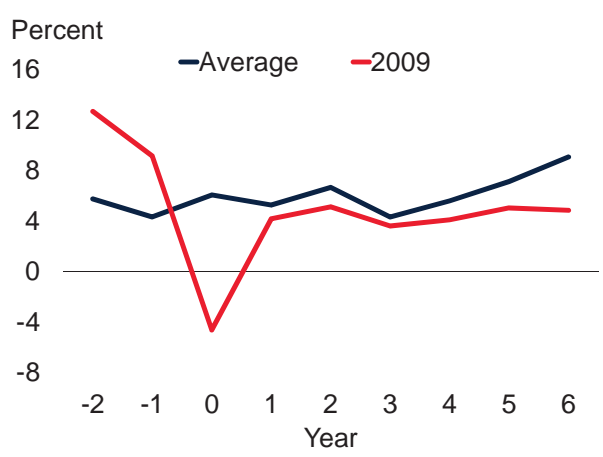

\section{B. EMDE commodity exporters}

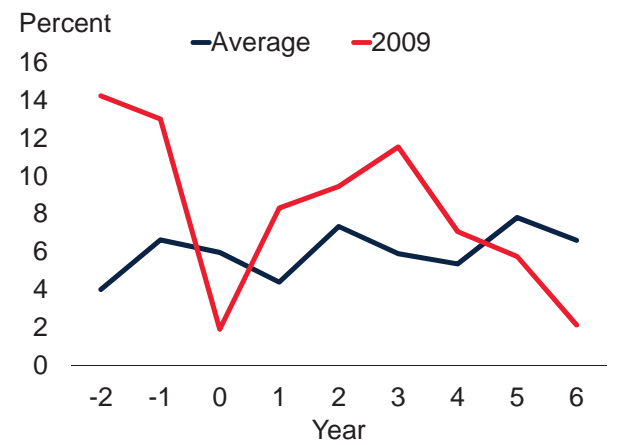

\section{World}

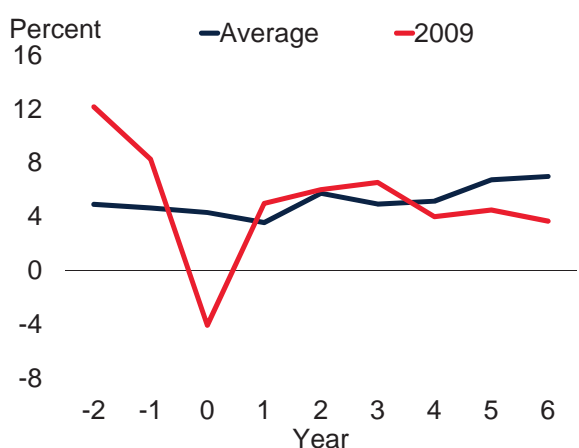

Sources: Haver Analytics, International Monetary Fund, Oxford Economics, World Bank.

Notes: Unweighted average investment growth. The horizontal axis denotes years. Zero refers to the year of the start of global downturns, which include global recessions and slowdowns. Average refers to unweighted average investment growth during global recessions and slowdowns of 1975, 1982, 1991, 1998, and 2001. 


\section{Figure 4. Economies with investment growing below its long-term average}

The share of EMDEs with investment growth below its long-term average has risen since 2012. The increase has been especially pronounced for commodity exporters.
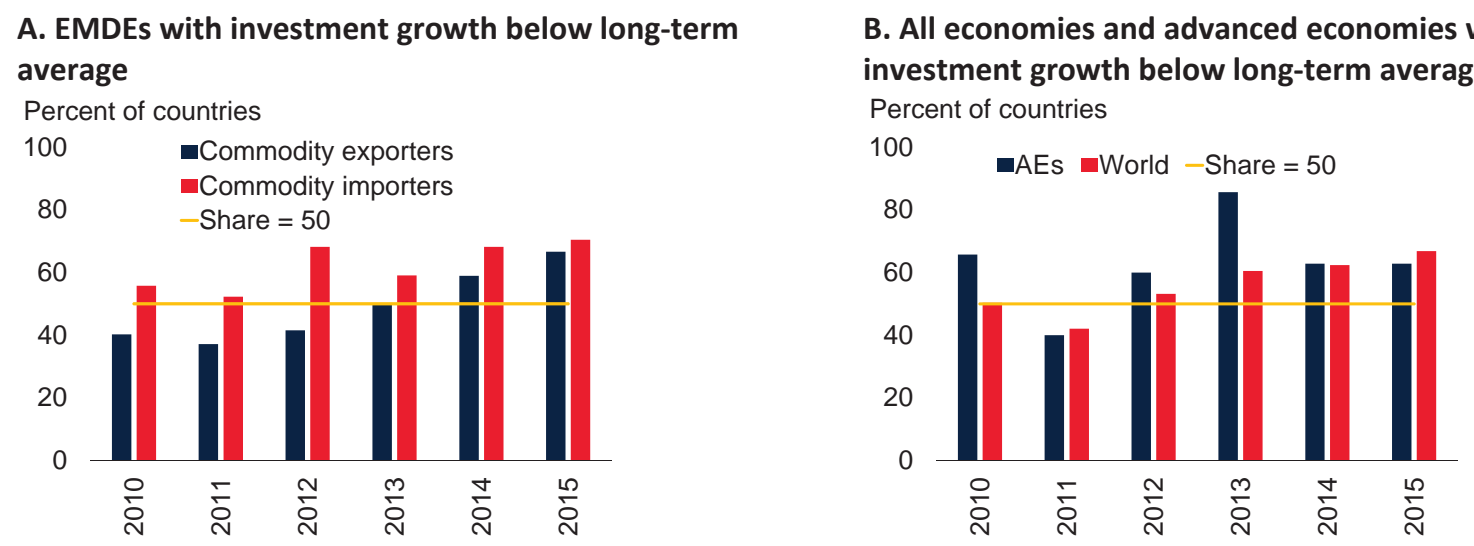

Sources: Haver Analytics; International Monetary Fund; Oxford Economics; World Development Indicators, World Bank.

A.B. Long-term averages are country-specific and refer to the period 1990-2008. The world sample includes 157 economies. The AE sample includes 35 economies, and the EMDE sample includes 78 commodity exporters and 44 commodity importers.

\section{Figure 5. Investment growth forecasts}

Short-term and long-term forecasts for investment growth in EMDEs have declined steadily since 2010.

\section{A. Next-year forecasts in EMDEs}

Percent

12

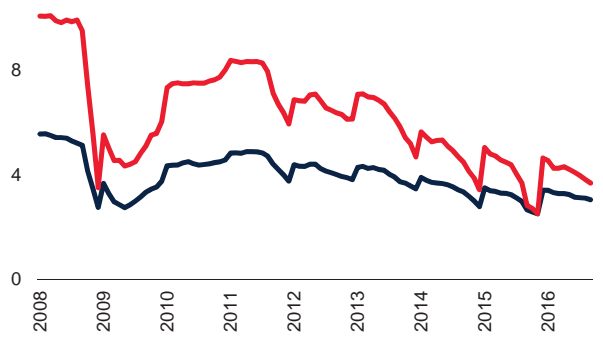

B. Forecasts: Five-year ahead expectations

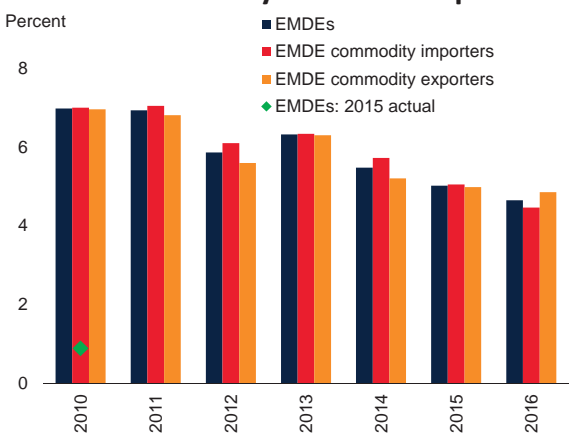

A. Next-year monthly Consensus Forecasts of investment and output growth. Unweighted averages across 18 EMDEs. Latest observation is October 2016.

B. Each column shows five-year-ahead Consensus Forecasts as of the latest available month in the year denoted. Unweighted averages among $11 \mathrm{EMDE}$ commodity importers and $10 \mathrm{EMDE}$ commodity exporters. Diamond denotes average actual investment growth in 2015 for 21 EMDEs. Last observation is for October 2016. 
Figure 6. Global financial conditions and activity

Global financing conditions have been exceptionally benign from 2010 until late 2016, with policy rates in EMDEs and AEs at historic lows. Since 2010, output growth has slowed sharply in EMDEs and has been mediocre in AEs.
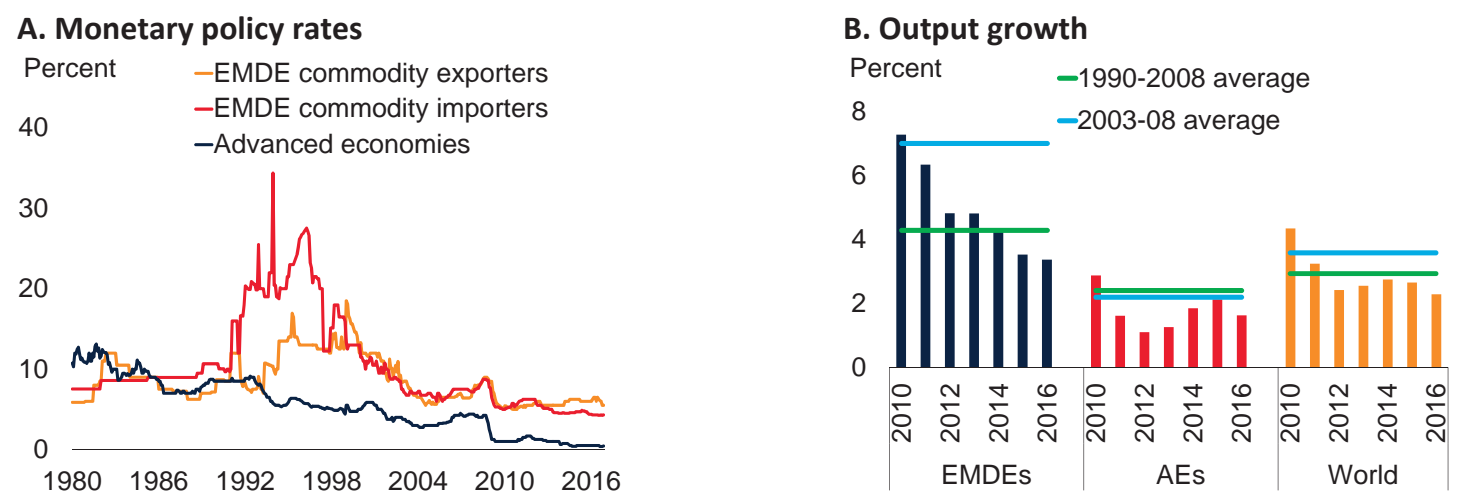

Sources: Haver Analytics, World Bank.

A. Medians for available data for 69 EMDEs and 26 AEs. Last observation is for November 2016.

B. Weighted averages.

\section{Figure 7. Terms of trade and investment growth}

The terms of trade of commodity exporters have deteriorated since 2011, reflecting the 30-60 percent declines in global energy, metals, and agricultural commodity prices from their early-2011 peaks. EMDEs with larger declines in their terms of trade experienced lower investment growth over 2010-15.

\section{A. Cumulative change in commodity prices}

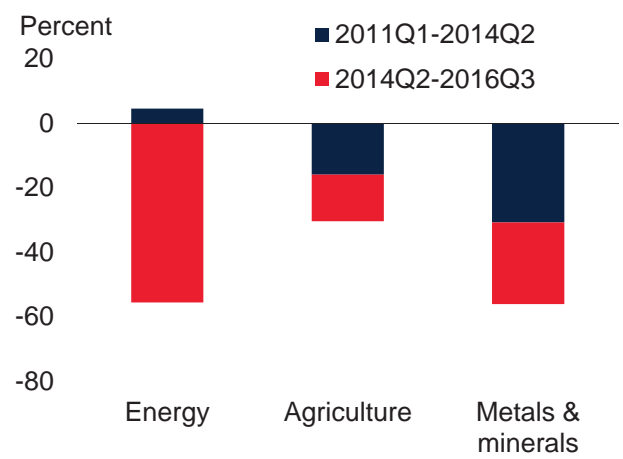

B. Investment growth in EMDEs with high and low changes in terms of trade, 2010-15 Percent

8

6

4

2

0

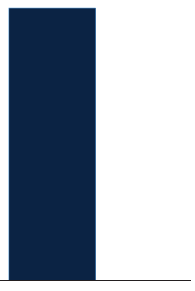

High

Source: World Bank.

A. Energy index includes crude oil (85 percent weight), coal, and natural gas. Agriculture index includes 21 agricultural commodities. Metals and minerals index includes 6 metals traded on the Land \& Metal Exchange, plus iron ore.

B. "Low" and "High" indicates annual terms of trade growth in the bottom and top one-thirds of the distribution, respectively. Difference in medians between "high" and "low" subsamples is significant at the five percent level. Group medians for 108 EMDEs during 2010-15. 
Figure 8. FDI flows and investment growth

Since 2010, weak investment growth has partly reflected shrinking FDI inflows among both EMDE commodity importers and exporters.

\section{A. FDI inflows to GDP in EMDEs}
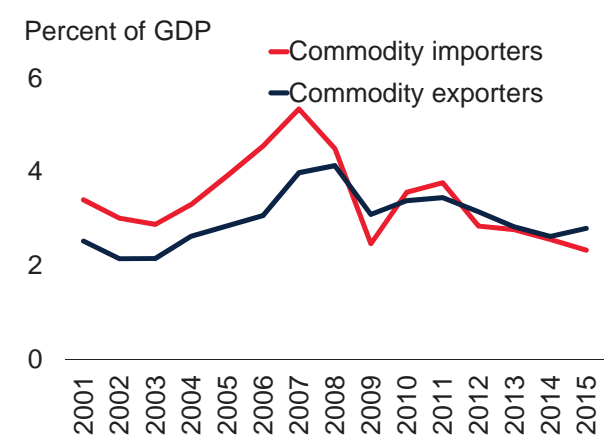

\section{B. Investment growth in EMDEs with high and low FDI inflows, 2010-15}

Percent

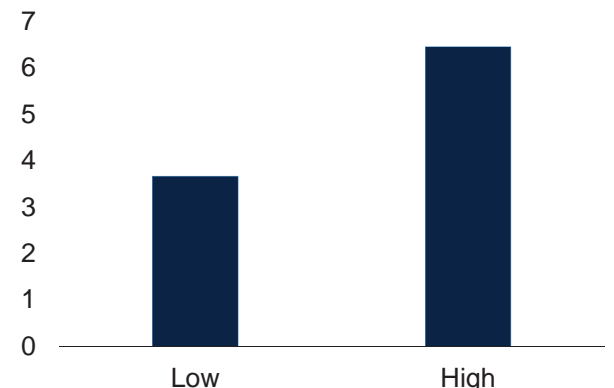

Sources: International Monetary Fund, World Bank.

A. Gross FDI inflows as ratios to GDP. Weighted averages. Includes 75 EMDEs.

B. "Low" and "High" indicate annual change in the FDI to GDP ratio in the bottom and top one-thirds of the distribution, respectively. Difference in medians between "high" and "low" subsamples is significant at the five percent level. Group medians for 120 EMDEs during 2010-15.

Figure 9. Political stability and investment growth

Weak investment growth compared to pre-crisis rates partly reflects reduced political stability since the global financial crisis.

\section{A. Political stability in EMDEs}

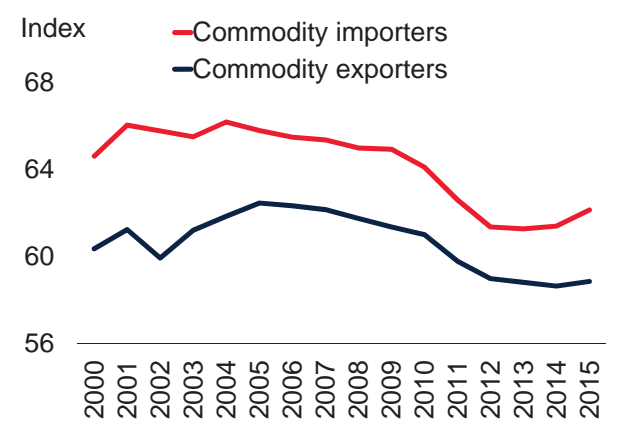

B. Investment growth in EMDEs with strong and weak improvement in political stability, 2010-15

Percent

6

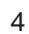

2

Weak improvement Strong improvement

Sources: Political Risk Services International Country Risk Guide (ICRG).

A. Lines show unweighted annual average, as measured by the ICRG index, for each group. A decrease in the index denotes deteriorating political stability. Includes 95 EMDEs.

B. "Strong improvement" and "Weak improvement" indicate improvement in political stability from 2010-15 in the top and bottom one third of the distribution, respectively. Difference in medians between "strong improvement" and "weak improvement" subsamples is significant at the ten percent level. Group medians for 61 EMDEs during 2010-15. 
Figure 10. Private debt and investment growth

Domestic private debt has risen sharply in EMDEs since the global financial crisis. EMDEs with larger private debt experienced slower investment growth during 2010-15.

\section{A. Private debt in EMDEs}

Percent of GDP

60

40

20

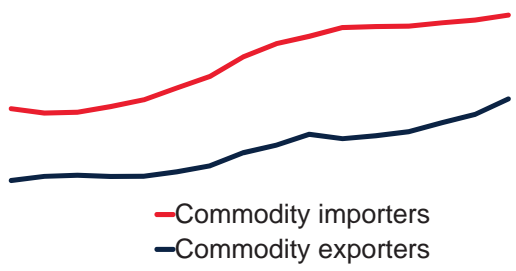

0

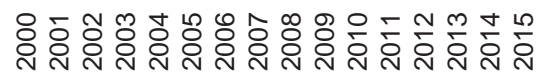

B. Investment growth in EMDEs with high and low private debt-to-GDP ratios, 2010-15

Percent

7

6

5

4

3

2

1

0

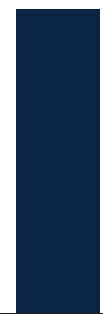

Low

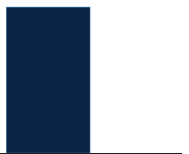

High

Source: World Bank.

Notes: Private debt refers to domestic credit to private sector by banks as percent of GDP.

A. Unweighted averages. Includes 115 EMDEs.

B. "Low" and "High" indicate median credit-to-GDP ratios over 2010-15 in the bottom and top one-thirds of the distribution, respectively. Difference in medians between "high" and "low" subsamples is significant at the five percent level. Group medians for 107 EMDEs during 2010-15.

\section{Figure 11. Correlates of investment growth}

Slowing output growth, declining FDI inflows, and worsening terms of trade (for commodity exporters) are associated with lower investment growth in EMDEs. Rising private debt and deteriorating political stability are additional headwinds for many EMDEs.

\section{A. Correlates of investment growth}

Variable Effect

\begin{tabular}{lc} 
Real GDP growth & + \\
Increase in FDI inflows & + \\
Political stability & + \\
Private debt & $\ldots$ \\
Private debt squared & - \\
Terms of trade improvement & + \\
Reform spurt & + \\
\hline
\end{tabular}

Source: World Bank.

Notes: Estimated impact of explanatory variables on investment growth in 73 EMDEs during 1998-2015, based on a panel regression with country fixed effects. The explanatory variables denoted with plus/minus signs are significant at the five percent level. Details are discussed in Annex 1. 
Figure 12. Spillovers from the United States and the Euro Area

Weak growth in the United States and the Euro Area has had adverse spillovers on output and investment in EMDEs.

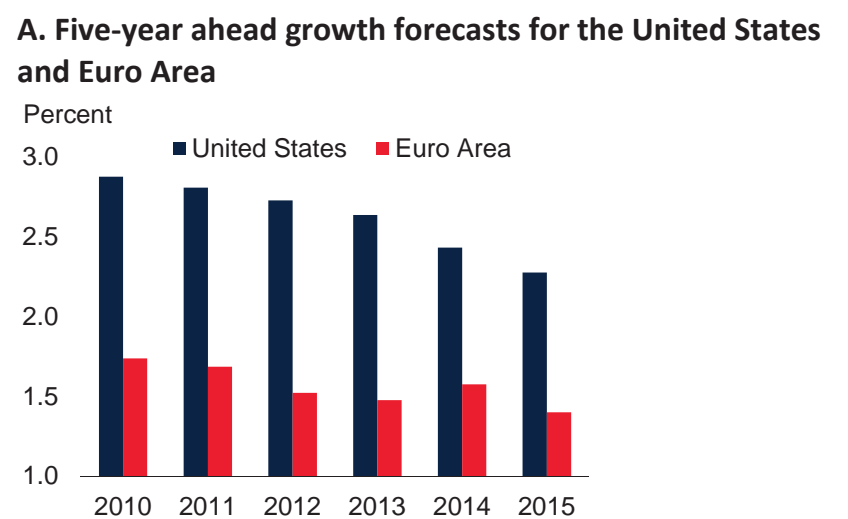

C. Spillovers to EMDE output growth from decline in U.S. output growth

Percentage points

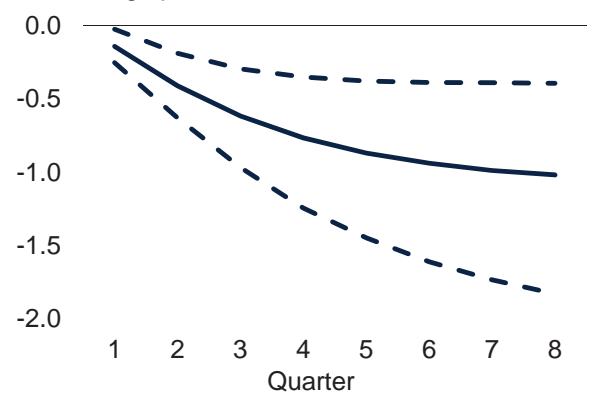

E. Spillovers to EMDE investment growth from decline in U.S. output growth

Percentage points

1.0

0.0

$-1.0$

$-2.0$

$-3.0$

$-4.0$

$-5.0$

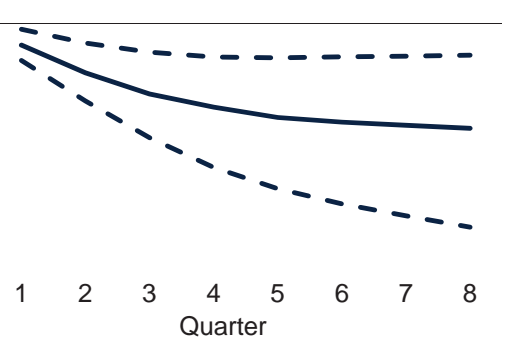

B. Import intensity of demand components, 2014

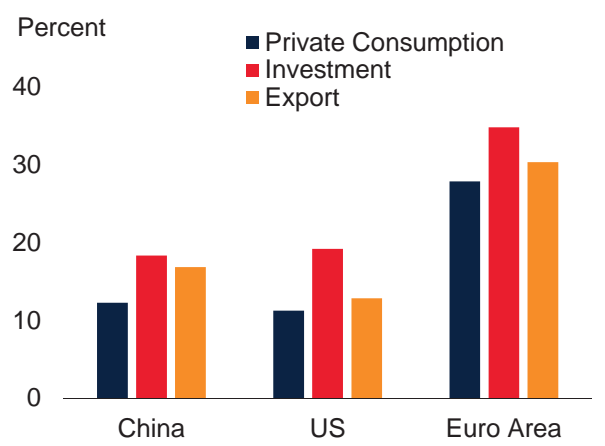

D. Spillovers to EMDE output growth from decline in Euro Area output growth

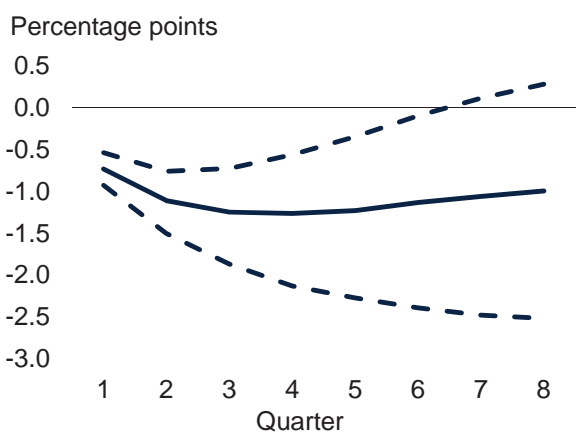

F. Spillovers to EMDE investment growth from decline in Euro Area output growth

Percentage points

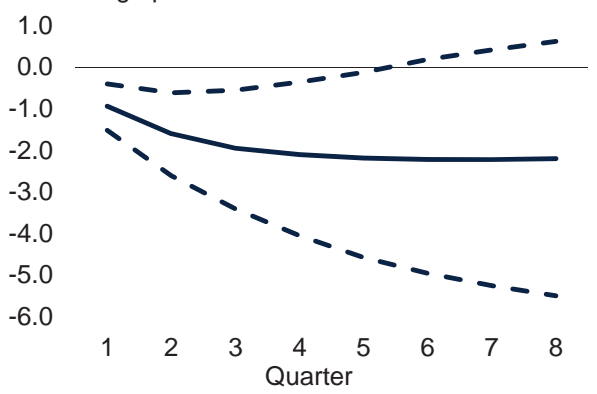

Sources: Consensus Economics, World Bank estimates, World Input-Output Database.

A. Five-year ahead Consensus Forecasts as of the latest available month in the year denoted.

C.-F. Cumulative impulse response of weighted average EMDE output growth (C.D.) or investment growth (E.F.) at 1-8 quarters to a 1 percentage point decline in growth in real GDP in the United States (C.E.) and Euro Area (D.F.). Growth spillovers based on a Bayesian vector autoregression of world GDP growth (excluding the source country of spillovers), output growth in the source country of the shock, the U.S. 10-year sovereign bond yield, JP Morgan's EMBI index, investment (E.F.) or output (C.D.) in EMDEs excluding China. The oil price is exogenous. Blue dotted lines denote 16th-84th percentile confidence intervals, and blue solid lines denote median responses. Sample includes 18 EMDEs (Brazil, Bulgaria, Chile, Costa Rica, Hungary, India, Indonesia, Malaysia, Mexico, Paraguay, Peru, the Philippines, Poland, Romania, Russia, South Africa, Thailand, and Turkey) from 1998Q1-2016Q2. 


\section{Figure 13. Slowdown in investment and global trade}

The investment growth slowdown across the world has been accompanied by a downturn in the growth of exports as well as capital goods trade.

\section{A. World investment and exports}

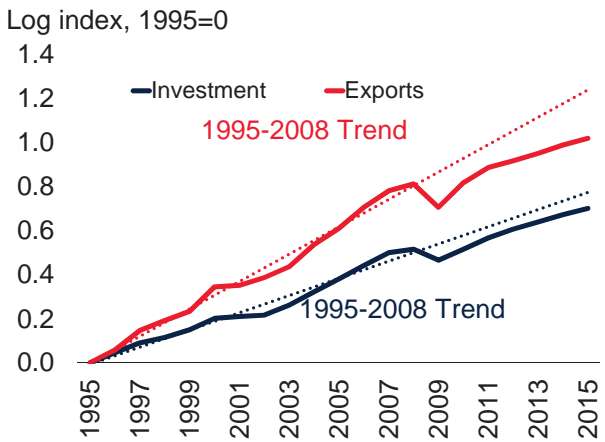

C. Global capital goods trade and investment

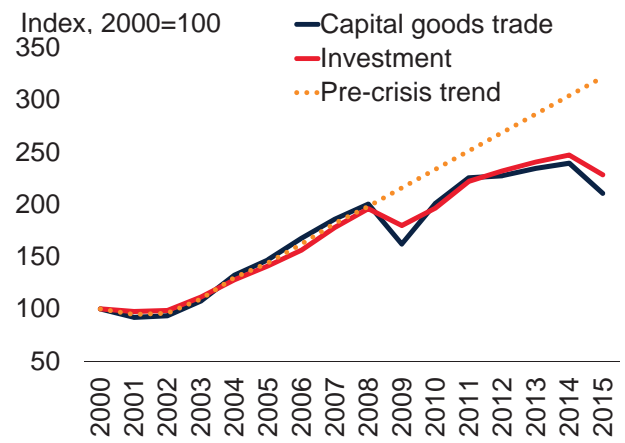

B. Investment and exports growth: EMDEs

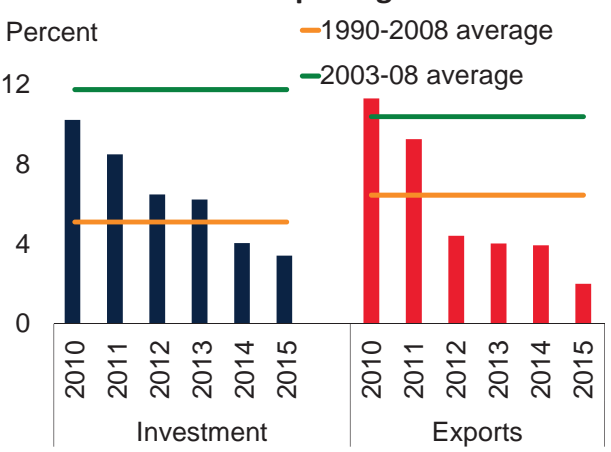

D. Investment by 5,000 largest multinational companies

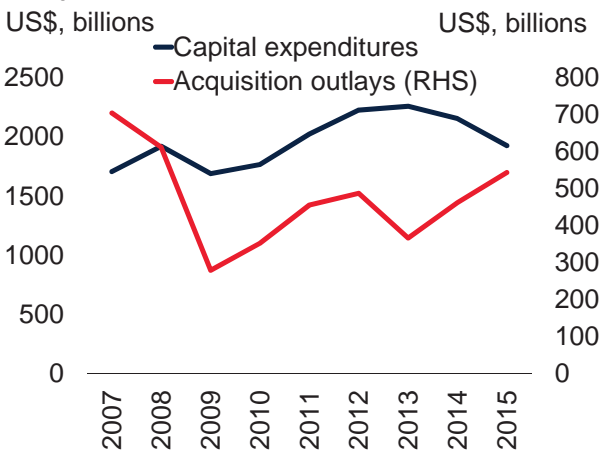

Sources: Haver Analytics; Thomson ONE; UNCTAD (2016); World Integrated Trade Solution, World Bank; World Bank.

A. Denotes levels of real gross fixed investment as well as exports.

B. Weighted averages. Long-term average for investment starts in 1991 due to data availability.

C. Capital goods trade and gross fixed capital formation expressed in current U.S. dollars. Trend line shows the pre-crisis (2003-

08) trend of the average of capital goods trade.

D. Top 5,000 MNEs capital expenditures and acquisition outlays based on data from Thomson ONE. 


\section{Figure 14. Labor productivity, TFP, and investment}

Slowing capital accumulation and total factor productivity growth have lowered EMDE income catch-up and labor productivity growth. Labor productivity growth has slowed in EMDEs since the crisis, most markedly in economies with relatively low investment growth.

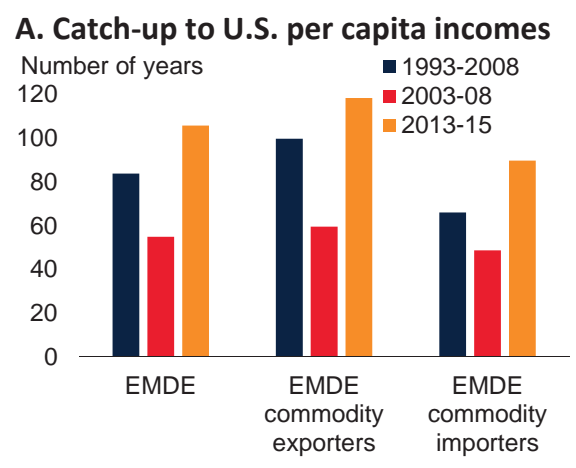

C. Changes in TFP and investment growth: 2010-15

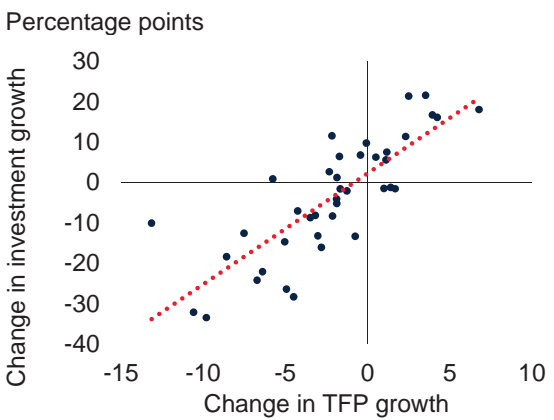

\section{E. Labor productivity growth in EMDEs}

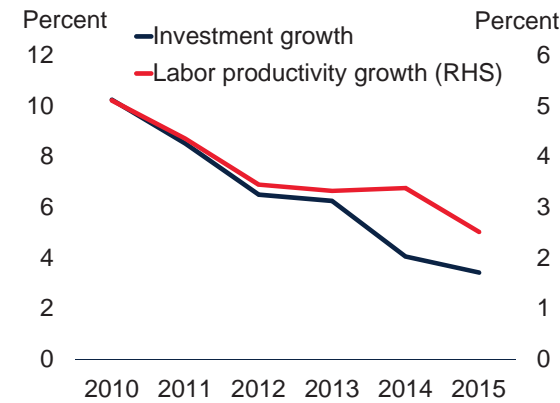

\section{B. Average TFP growth}

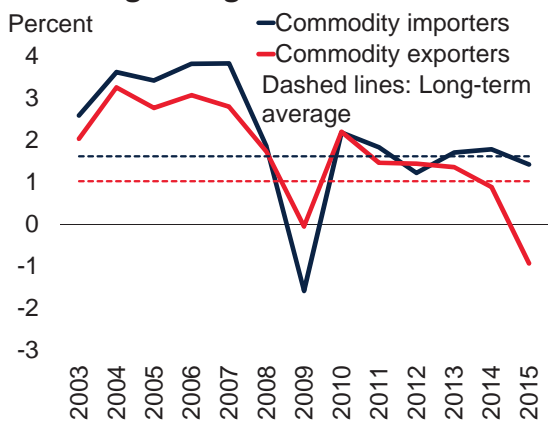

\section{Differential between EMDEs and AEs in per} capita investment and GDP growth

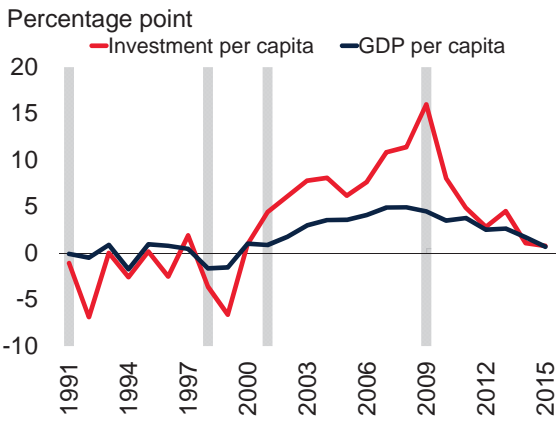

F. Labor productivity growth in EMDEs with high and low investment growth, 2010-15

Percent

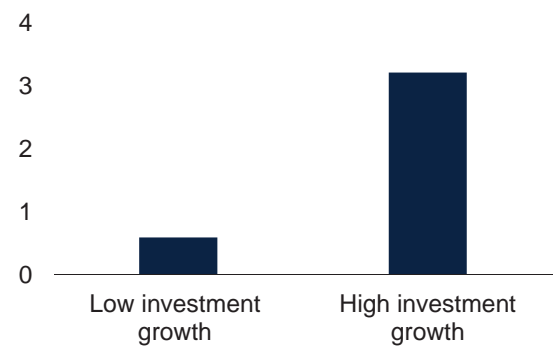

Sources: Haver Analytics, International Labor Organization, International Monetary Fund, Penn World Table, World Bank. A. Number of years needed to catch-up with 2015 real per capita GDP level in the United States, assuming average growth rates over each period denoted for each group. B. Unweighted averages. TFP calculated as residual from the growth-accounting framework in Didier et al. (2015). Dashed lines indicate long-term average for 1990-2008 for each respective group. C. Correlation of change in investment growth from 2010-15 with change in TFP growth over the same period. Red dotted line denotes the linear regression line. Includes 40 EMDEs. D. Weighted averages. Difference between EMDEs and AEs. The shaded areas are global recessions and downturns. E. Weighted averages. Labor productivity is defined as real output per person engaged. F. "Low" and "High" indicate annual growth rates in real investment in the bottom and top one-third of the distribution, respectively. Difference in medians between "high" and "low" subsamples is significant at the five percent level. Group medians for 123 EMDEs during 2010-15. 
Figure 15. Public and private investment

In EMDEs, both public and private investment have declined from 2009-10 peaks. In AEs, post-crisis public investment contracted as private investment growth stabilized and picked up.

\section{A. Public investment growth}

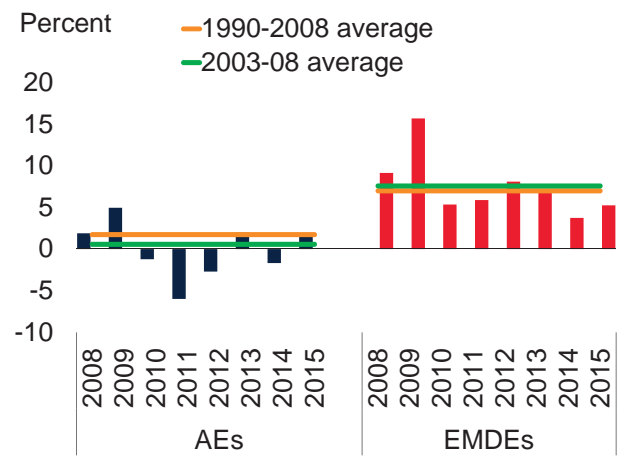

\section{B. Private Investment Growth}

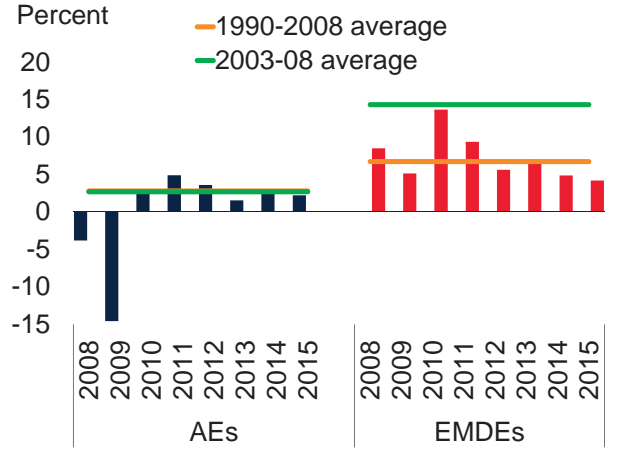

Sources: Eurostat, General Statistics Office of Vietnam, Haver Analytics, International Monetary Fund, Ministry of National Economy of the Republic of Kazakhstan, OECD, Reserve Bank of India, Sri Lanka Ministry of Finance, World Bank.

A.B. Public and private investment growth rates are weighted averages of gross fixed capital formation growth rates in the public and private sectors, respectively, in constant 2005 U.S. dollars. The sample includes 20 advanced economies and 99 EMDEs from 1990 to 2015.

\section{Figure 16. Public investment and growth}

Public investment boosts output growth and crowds-in private investment, but the effects dissipate after about two years.

\section{A. Cumulative impact on output of a 1 percent increase in public investment}

Percent deviation from the baseline

$$
0.3
$$

0.2

0.1

0.0

$-0.1$

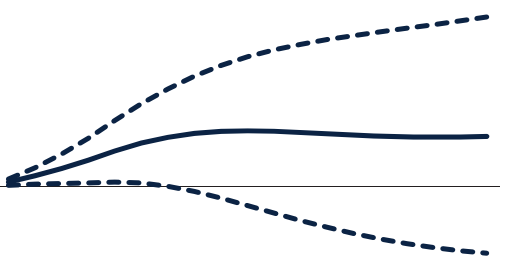

$-0.2$

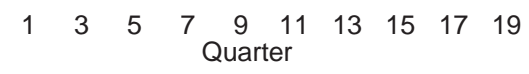

B. Cumulative impact on private investment of a 1 percent increase in public investment

Percent deviation from the baseline

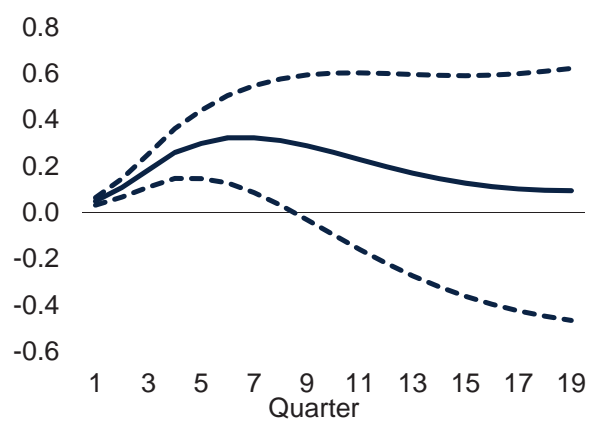

Sources: International Monetary Fund, World Bank estimates.

Notes: The graphs show the cumulative impulse responses (percentage points) of output and private investment due to a positive shock to government investment, based on a sample of 8 EMDEs for 1998Q1-2016Q2.Variables included are, in this ordering, real government investment, real GDP, real private investment, current account balance, and the real effective exchange rate. The shock size is such that government investment increases by 1 percent from the baseline on impact. Solid lines represent the median, and dotted bands are the 16-84 percent confidence bands. 
Figure 17. Fiscal and monetary policy space

Elevated debt and wide fiscal deficits restrict the use of counter-cyclical fiscal stimulus in a number of EMDEs. Above-target inflation, especially in many commodity-exporting EMDEs, constrains the use of monetary stimulus.
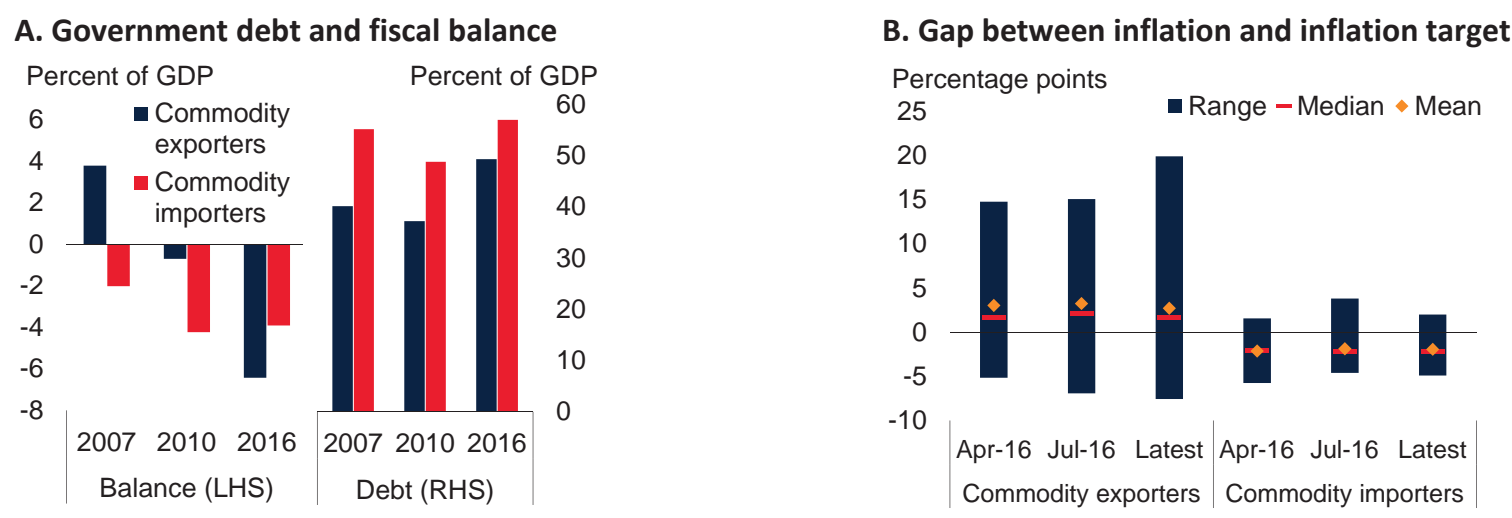

Sources: Central Banking News, Haver Analytics, International Monetary Fund.

A. "Balance" stands for fiscal balance and reflects the unweighted average of 89 commodity-exporting and 62 commodityimporting EMDEs. "Debt" stands for general government debt and reflects unweighted average gross government debt of 86 commodity-exporting and 61 commodity-importing EMDEs.

B. Figure includes 22 commodity-exporting and 18 commodity-importing countries with a stated inflation target and for which current inflation data is available. Latest observation is for Nov 2016.

Figure 18. Infrastructure, education, and health investment needs

Substantial gaps in infrastructure, education, and health investment needs remain across the world.

\section{A. Global infrastructure investment gap}

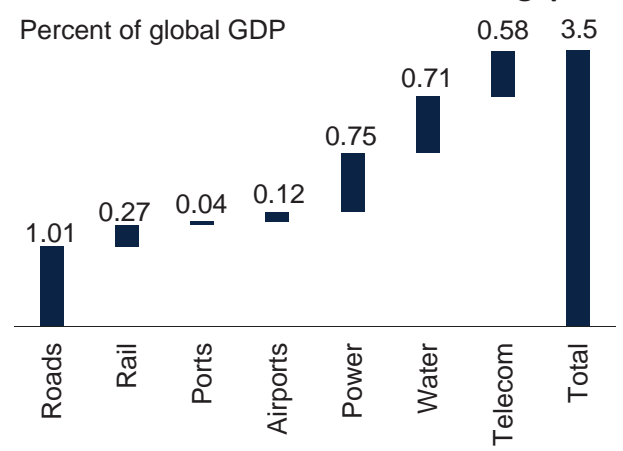

B. Investment gaps in reaching SDG US\$, billions

- Investment gap, average 2015-30

1,200 Investment, 2014

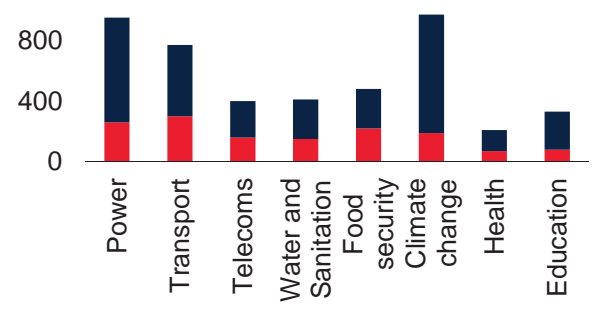

Sources: UNCTAD (2014), World Bank (2016b), World Bank estimates.

A. The figure shows global investment in infrastructure (as percent of GDP) required over 2015-30, as projected by McKinsey Global Institute.

B. Investment refers to capital expenditure. Upper bounds for the estimated investment needs are reported. Red column denotes 2014 or latest available year. SDG refers to the United Nation's Sustainable Development Goals. 


\section{Figure 19. Investment and governance reform}

Reform spurts are significantly associated with higher investment growth. Since 2011, improvements in the business climate have continued, but at a slower pace.

\section{A. Growth differentials during reform spurts and setbacks}

Growth differential, in percentage points

3

$-3$

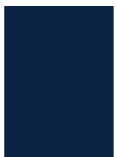

$-6$

Reform spurt

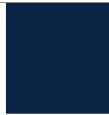

Reform setback
B. Distance to frontier of Ease of Doing Business

Distance to frontier score

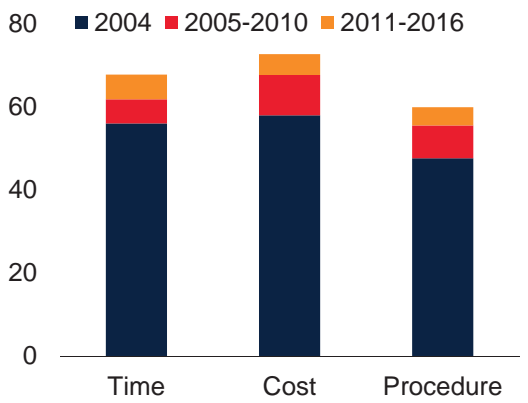

Sources: Doing Business Report, World Bank; Worldwide Governance Indicators, World Bank; Haver Analytics; World Economic Outlook, International Monetary Fund.

A. The columns show the cumulative investment growth differential of economies during a reform spurt or setback episode, relative to those that experienced neither spurts nor setbacks. Spurt (setback) is defined by a two year increase (decrease) by two standard deviations in one or more of indexes of regulatory quality, government effectiveness, rule of law, and control of corruption. Differentials are based on estimates from a panel data regression with time and country fixed effects. The sample includes 75 reform spurt episodes and 71 reform setback episodes among 97 EMDEs over 1996-2015. The growth differential during reform spurt episodes is significant at the ten percent level. See Annex $2 \mathrm{E}$ for more details. B. Indicates proximity in score to country with the highest-ranking (best) scores for Ease of Doing Business across all time periods with available data. A higher distance to frontier score (DTF) indicates an easier business environment. Unweighted averages of 117 EMDEs. "Time" refers to the average DTF of the time to start a business, obtain construction permits, connect electricity, registering property, paying taxes, and enforcing contracts. "Cost" refers to the average DTF of the costs to starting a business, connect electricity, registering property, and enforcing contracts. "Procedure" refers to the average DTF of the number of procedures to starting a business, obtain construction permits, connecting electricity, and registering property. Blue column denotes the DTF level in 2004. The red and orange columns denote the change in DTF over the respective periods. Each year denoted refers to June of previous year to June of current year. 


\section{Appendix 1. Investment-less credit booms}

Since the global financial crisis, private credit has risen sharply in several emerging market and developing economies (EMDES) and advanced economies (AEs). During this period, credit booms have been unusually "investment-less." Virtually none of the post-crisis credit booms have been accompanied by the investment surges that were common in earlier episodes. The absence of investment surges during credit booms is accompanied by lower growth once the credit boom unwinds.

Since the global financial crisis, credit to the nonfinancial private sector has risen rapidly in several EMDEs while investment growth has slowed. In the past, credit booms have often financed rapid investment growth, with investment subsequently stalling. Against this background, this appendix addresses the following questions:

- How has total investment, including both private and public investment, evolved during credit booms and deleveraging episodes in EMDEs?

- How often have credit booms been accompanied by investment booms?

- How has output growth evolved during credit booms and deleveraging episodes in EMDEs?

The results indicate that while investment often rose sharply during previous credit booms, this has not been so for credit booms since 2010. This pattern is cause for concern since, when credit booms unwind, GDP growth tends to contract more if the credit boom was not accompanied by an investment surge.

Data and Methodology. Credit to the nonfinancial private sector consists of claims-including loans and debt securities-on households and nonfinancial corporations by the domestic financial system as well as external creditors. Details of the dataset can be found in Annex $1 \mathrm{~A}$.

A credit boom is defined as an episode during which the private sector credit-to-GDP ratio is more than 1.65 standard deviations above its Hodrick-Prescott (HP) filtered trend in at least one year (World Bank 2016b; Ohnsorge and Yu 2016). An episode starts when the deviation first exceeds one standard deviation and ends when the credit-to-GDP ratio begins to fall. Conversely, a deleveraging episode is defined as an episode during which the private sector credit-to-GDP ratio is more than 1.65 standard deviations below trend in at least one year. The deleveraging episode starts when the ratio falls more than one standard deviation below trend and ends when the credit-to-GDP ratio begins to climb.

Credit booms and deleveraging episodes are studied within a 7-year event window that covers their peak or trough years $(t=0)$, the three prior years, and the three following years. In the sample used here, there have been 59 credit booms and 28 deleveraging episodes in EMDEs. A typical credit boom lasted about 1.7 years, while an average deleveraging episode lasted about 1.4 years.

\section{Investment behavior during credit booms and deleveraging episodes}

Credit booms have typically been associated with rising investment. During the median credit boom over the past two to three decades, real investment grew by 1 percentage point of GDP above its long-term (HP-filtered) trend until the peak of the credit boom (Figure 1.1). In a quarter of previous credit booms, the real investment-to-GDP ratio dropped about 2 percentage points below its long-term (HP-filtered)

Note: This appendix was prepared by Shu Yu. 
trend over the two years after the peak. Investment swung sharply in the most severe credit boom and bust episodes. For example, during the Asian financial crisis of the late 1990s, in the median affected EMDE, investment contracted by 3 percentage points of GDP in 1998 and by 5.6 percentage points of GDP in $1999 .{ }^{26}$

Similarly, investment growth slowed during deleveraging episodes. Real investment dropped below its long-term trend by about 2 percentage points of GDP during the last three years of the median deleveraging episode (Figure 1.1). After the trough of a typical deleveraging episode, real investment growth bounced back and, within three years, rose near or slightly above its long-term trend.

\section{Credit and investment booms together}

Although investment growth tended to rise during credit booms, not all credit booms were associated with investment booms. For instance, Mendoza and Terrones (2012) document that the coincidence between investment booms and credit booms in EMDEs was about 34 percent (26 percentage points lower than the coincidence in AEs). The moderate coincidence of credit booms and investment booms may reflect credit booms that mainly fueled consumption (Mendoza and Terrones 2012; Elekdag and Wu 2013). In a quarter of past credit booms, consumption rose above its Hodrick-Prescott filtered trend by 3 percentage points of GDP during the peak of the credit boom. Consumption on average fell below trend by about 1 percentage point of GDP during deleveraging episodes (Figure 1.1).

Following former studies and in parallel to credit booms, investment surges are defined as years when the investment-to-GDP ratio is at least one ( 1.65 for investment booms) standard deviation higher than its long-term Hodrick-Prescott filtered trend. Similarly, episodes of investment slowdown are defined as years in which the investment-to-GDP ratio is at least one standard deviation below its Hodrick-Prescott filtered trend. ${ }^{27}$

Investment surges in AEs occurred with credit booms more often than in EMDEs, with a more rapid rise in investment. In EMDEs, about 40 percent of credit booms were accompanied by investment surges around the peak year of a credit boom (Figure 1.2). More than 65 percent of investment surges that coincided with credit booms during the peak year qualified as investment booms in advanced economies, but only 56 percent of such investment surges turned out to be investment booms in EMDEs.

After the global financial crisis, the coincidence between credit booms and investment surges during the peak year of a credit boom dropped significantly (Figure 1.2). By 2007, about half of the EMDEs in a credit boom were also in an investment surge. However, from 2010 onwards, there is virtually no EMDE that was both in a credit boom and in an investment surge. The number of EMDEs in a credit boom increased from two in 2010 to ten in 2015 (Azerbaijan, Bolivia, China, Cote d'Ivoire, Kenya, Kuwait, Oman, the Philippines, Qatar, and Turkey) while the number of EMDEs in investment surges dropped from eight to four. ${ }^{28}$ In AEs, both the number of countries in a credit boom and the number of countries in an investment surge fell from around five to almost zero.

\footnotetext{
${ }^{26}$ The directly affected EMDEs include China, Indonesia, Malaysia, Mongolia, the Philippines, and Thailand.

${ }^{27}$ The results are similar when investment growth, instead of the investment-to-GDP ratio, is used.

${ }^{28}$ The four countries are Colombia, Namibia, the Philippines, and Saudi Arabia. The identification of Saudi Arabia is not supported by investment growth data.
} 
In several countries, rapid credit growth fueled above-average consumption growth (Bangladesh, Bolivia, India, and Ghana) but no investment surge. During the period between 2012 and 2015, consumption in EMDEs was about 0.5 percentage point of GDP above trend, near or above its median expansion during past credit boom episodes (Figure 1.1).

\section{Output during credit booms and deleveraging episodes}

In general, output has expanded during credit booms, but by less than investment (Mendoza and Terrones 2012). Before the median credit boom peaked, output increased, on average, by about 3 percent above trend in cases where there was an investment surge and by about 1 percent above trend before the peak years of credit booms in cases when there was no investment surge (Figure 1.3). As credit booms unwound from their peaks, output dropped below trend by more than 2 percent over two years in the absence of investment surges, but by less than half as much when there were investment surges. The more disruptive unwinding of credit booms without investment surges may reflect the lack of a boost to potential output from capital accumulation that could be provided by an investment surge. In the recent wave of credit surges since 2012, EMDE output has evolved similarly to that of past credit booms without investment surges.

During the median deleveraging episode, output fell by almost 2 percent below trend (Figure 1.3). If accompanied by an investment slowdown, the decline in output was sharper as output fell from about 1 percent below trend in the run-up to the deleveraging to about 3 percent below trend around its trough. It took about three years for output to move back to its trend after a deleveraging episode.

\section{Conclusion}

Since 2010, several EMDEs have experienced rapid private sector credit growth. In contrast to many precrisis episodes, however, these credit surges have typically not been accompanied by investment surges. Output growth during the most recent credit surges has also been lower than in previous episodes. While output has contracted as credit booms have unwound, it has contracted more when credit booms have occurred without investments surges. 


\section{Figure 1.1 Investment growth during credit booms and deleveraging episodes}

In EMDEs, in the median credit boom, investment grew by about 1 percentage point of GDP above its long-term trend until the credit boom peaked. It dropped below its long-term trend by 1-2 percentage points of GDP before deleveraging episodes reached their troughs.

\section{A. Investment during credit booms}

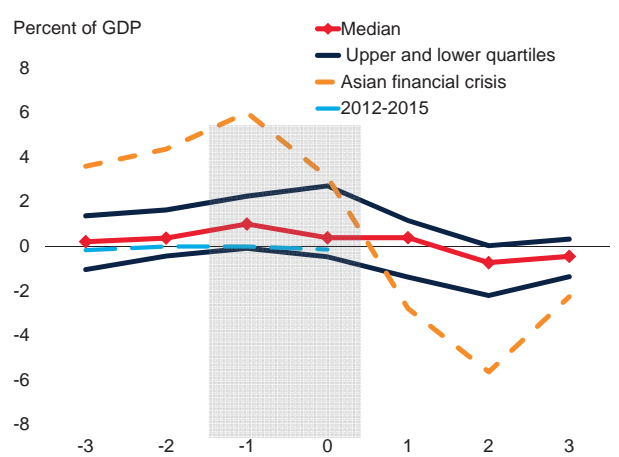

C. Consumption during credit booms

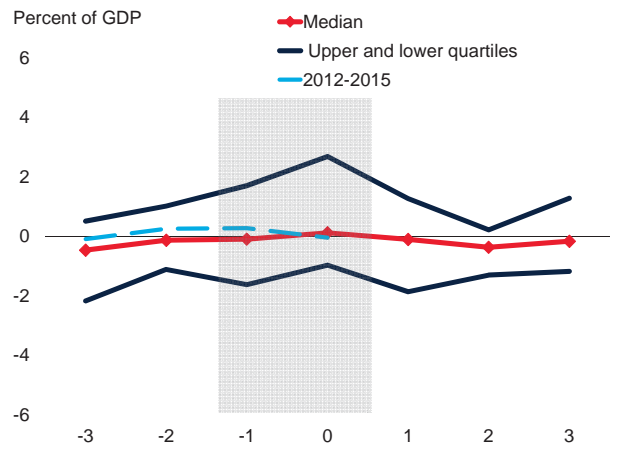

\section{B. Investment during deleveraging episodes}

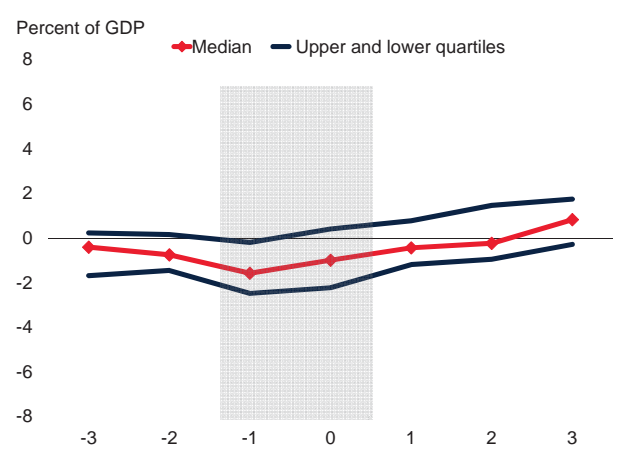

D. Consumption during deleveraging episodes

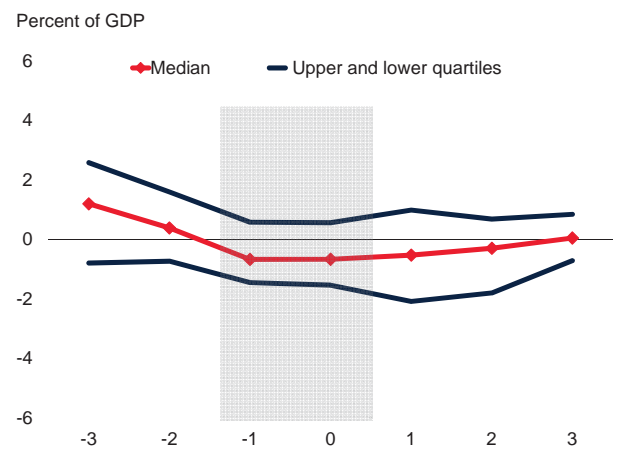

Sources: Bank for International Settlements; Haver Analytics; International Financial Statistics, International Monetary Fund; World Development Indicators, World Bank.

Notes. The red lines show sample medians while the blue lines show the corresponding upper and lower quartiles. A credit boom is defined as an episode during which the cyclical component of the nonfinancial private sector credit-to-GDP ratio (using a Hodrick-Prescott filter) is larger than 1.65 times its standard deviation in at least one year. The episode starts when the cyclical component first exceeds one standard deviation and ends in a peak year ("0") when the nonfinancial private sector credit-to-GDP ratio declines in the following year. A deleveraging episode is defined correspondingly. To address the end-point problem of a Hodrick-Prescott filter, the dataset is expanded by setting the data for 2016-18 to be equal to the data in 2015 . Sample is for available data over 1980-2015 for 55 EMDEs. 2015 data are not available for Gabon, Nigeria, Senegal, and Venezuela, RB. Data are not available for Argentina until 1994, Brazil until 1993, China until 1984, Hungary until 1989, Poland until 1992, Russia until 1995, Saudi Arabia until 1993, and Turkey until 1986. Please see the main text of World Bank (2016b) for a detailed description of the sample.

A.B. The cyclical component of investment in percent of GDP (derived by Hodrick-Prescott filter). The yellow dashed line is the median annual investment growth rate of the six EMDEs (China, Indonesia, Malaysia, Mongolia, the Philippines, and Thailand) that were affected by the 1997 Asian Financial Crisis (year 1997 is set to be $t=0$ ). The light blue dashed line for 2012-15 shows the sample median for the corresponding period.

C.D. The cyclical component of private consumption in percent of GDP (derived by Hodrick-Prescott filter). The light blue dashed line for 2012-15 shows the sample median for the corresponding period. 2015 data are not available for Bahrain, Bolivia, Costa Rica, Hungary, India, Jamaica (also for 2000-01), Kazakhstan, Kuwait, Oman, Panama, Thailand, Tunisia, and data are not available for Zambia and Venezuela, RB (in 2014). 


\section{Figure 1.2 Coincidence between investment surges and credit booms}

Before the global financial crisis, about 40 percent of all credit booms in EMDEs were accompanied by investment surges around the boom's peak. Only one quarter of credit booms since 2010 have been accompanied by investment surges (and virtually none by investment booms).

\section{A. Investment surges during past booms in EMDEs \\ B. Investment surges during recent credit booms in EMDEs}
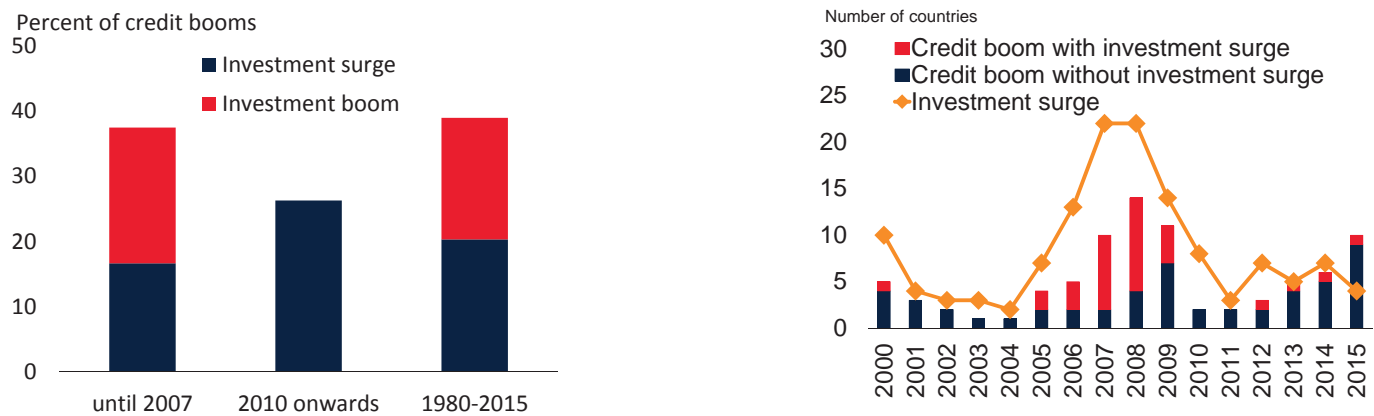

Sources: Haver Analytics; International Financial Statistics, International Monetary Fund; Bank for International Settlements; World Development Indicators, World Bank.

Notes. Credit booms are defined as in Figure 1.1. Investment surge is defined as years when the cyclical component of the investment-to-GDP ratio is at least one standard deviation (1.65 for investment booms) above the HP-filtered trend, while investment slowdown is a year when the cyclical component of the investment-to-GDP ratio is at least one standard deviation below the HP-filtered trend. Data availability as in Figure 1.1.

A. Investment surges during the peak year $(t=0)$ or the following year $(t=1)$.

\section{Figure 1.3 Output growth during credit booms and deleveraging episodes}

In EMDEs, output on average grew above its trend by 2 percent during credit booms and fell below trend by 2 percent during deleveraging episodes. Output growth during credit booms tended to be stronger when accompanied by investment surges. During deleveraging episodes, declines were deeper when accompanied by investment slowdowns.

\section{A. GDP during credit booms}

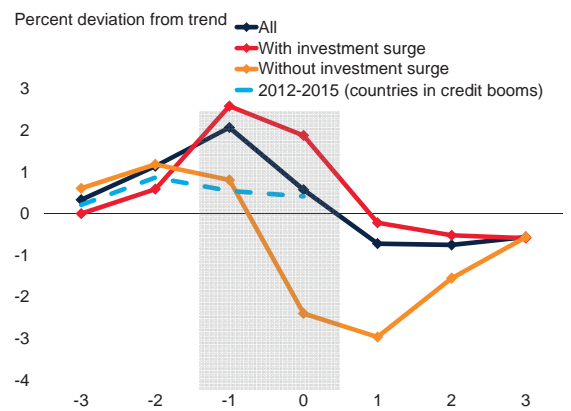

\section{B. GDP during deleveraging episodes}

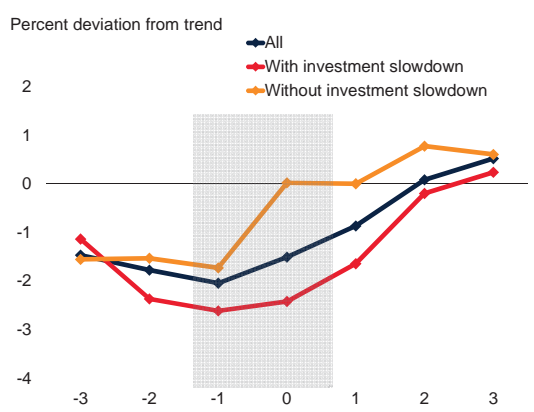

Sources: Bank for International Settlements; Haver Analytics; International Financial Statistics, International Monetary Fund; World Development Indicators, World Bank. Notes. Credit booms and deleveraging episodes are defined as in Figure 1.1 Investment surges and slowdowns are defined as in Figure 1.2. Data availability as in Figure 1.1.

A. Group medians for the cyclical components of GDP in percent of its trend (derived using a Hodrick-Prescott filter) for all credit booms (in blue), credit booms with investment surge (occurred in 1 year around $t=0$, in red), and credit booms without investment surge (in yellow). The mean cyclical components of GDP in percent of its HP-filtered trend for the ten countries (including Azerbaijan, Bolivia, China, Cote d'Ivoire, Kenya, Kuwait, Oman, the Philippines, Qatar, and Turkey) in credit booms in 2015 during 2012-2015 are in light blue dashed line. B. Group medians for the cyclical components of GDP in percent of its trend (derived using a Hodrick-Prescott filter) for all deleveraging episodes (in blue), deleveraging episodes with investment slowdown (occurred in 1 year around $t=0$, in red), and deleveraging episodes without investment slowdown (in orange). 


\section{Appendix 2. Implications of rising uncertainty for investment in EMDEs}

Political and policy-related uncertainty has increased since the global financial crisis for most EMDEs. EU policy uncertainty has reduced investment in the EU'S EMDE trading partners, and domestic policy uncertainty has weighed significantly on investment in Brazil. Global financial market uncertainty (as measured by the VIX) significantly affects EMDE investment.

Elevated macroeconomic and policy uncertainty after the crisis has contributed to weak investment growth in AEs (Kose and Terrones 2015). However, less is known about the implications of uncertainty for EMDEs. This appendix examines the effects of uncertainty on investment growth by addressing the following questions:

- What are the basic sources of uncertainty?

- How has uncertainty evolved in EMDEs since the 2008-09 crisis?

- How has uncertainty affected investment in EMDEs?

The results suggest a post-crisis rise in political and policy uncertainty in EMDEs and bouts of financial market uncertainty amidst ample global liquidity. Policy uncertainty in the European Union (EU)including that associated with the Euro Area crisis - has weighed on investment in the EU's EMDE trading partners in Europe and Central Asia. Domestic policy uncertainty has sharply curtailed investment in Brazil.

\section{Basic sources of uncertainty}

Although uncertainty is often discussed in policy debates, there is no universally agreed measure of it. This appendix uses three measures for EMDEs, the United States, as well as the EU.

- Financial market uncertainty. Financial market uncertainty is measured by a quarterly financial market volatility measure, which is constructed using the realized standard deviation of daily changes in stock price indexes (Bloom, Bond, and Van Reenen 2007; Bloom 2009; Gilchrist, Sim, and Zakrajsek 2014). The VIX index of implied volatility of the S\&P 500 stock market index in the United States is used as an indicator of global financial market volatility.

- Economic Policy Uncertainty. The Economic Policy Uncertainty (EPU) Index is a news-based measure to capture policy-related uncertainty developed by Bloom, Baker, and Davis (2016). The EPU index is constructed from counts of terms related to policy uncertainty appearing in newspapers in each country. This measure is available for four EMDEs: Brazil, China, India, and Russia.

- Political uncertainty. Political uncertainty is measured by the political risk rating developed by the Political Risk Services Group's (PRS) International Country Risk Guide (ICRG). The rating simply summarizes expert judgment on each economy's political environment. As used here, a higher value of the index reflects greater political risk. For the four EMDEs with available data, the ICRG risk scores are positively correlated with the EPU Index, suggesting overlap between political risk and policy uncertainty.

Note: This appendix was prepared by Jongrim Ha, Raju Huidrom and Congyan Tan. 


\section{Evolution of uncertainty in EMDEs since the 2008-09 crisis}

In most EMDEs, political and policy uncertainty were higher post-crisis (2010-2015) than pre-crisis (20032008), as indicated by the ICRG-based political uncertainty and EPU-based policy uncertainty measures (Figure 2.1). Political risk increased in more than four-fifths of EMDEs and policy uncertainty increased in all four major EMDEs for which data are available. In contrast, financial market volatility, as measured by the standard deviation of domestic stock market indexes, declined in most EMDEs, reflecting exceptionally accommodative monetary policies and record-low interest rates globally. The generally low post-crisis financial market volatility was disrupted by several bouts of global financial market uncertainty. The VIX, which in normal circumstances tends to fluctuate in the 10-30 range, surged to above 40 basis points during periods of intense market concerns about the future of the Euro Area (March-June 2010 and MaySeptember 2011) and about the stability of Chinese equity markets and growth prospects (July-August 2015).

\section{Impact of uncertainty on investment in EMDEs}

To assess the effects of uncertainty on investment during 1998Q1-2016Q2, a series of vector autoregressive models were estimated for $18 \mathrm{EMDEs}$. Two sources of uncertainty were distinguished: domestic and global. Global financial market uncertainty was captured by the VIX. Global policy uncertainty was captured by the EPU for the United States and the EU. Domestic policy uncertainty was captured by the EPU for Brazil. Details of the estimation are presented in Annex 1B.

- Global financial market uncertainty. Global financial market uncertainty shocks, as measured by spikes in the VIX, significantly reduced EMDE investment, in line with findings of earlier studies (Carriere-Swallow and Cespedes 2013). Specifically, a 10 percent increase in the VIX reduced average EMDE investment growth by about 0.6 percentage point within a year (Figure 2.2). Financial market uncertainty was the key source of the slowdown in EMDE investment growth in 2008-09. Bouts of global financial market uncertainty (such as during the Euro Area crisis, the 2013 Taper Tantrum, and the 2016 Brexit) also weighed on EMDE investment.

- Global policy uncertainty. Policy uncertainty in major AEs could also generate significant spillovers to EMDE investment. Policy uncertainty in the EU had an especially sizable impact on investment in EMDEs in Europe and Central Asia: a 10 percent increase in EU policy uncertainty reduces their investment growth by 0.6 percentage point within a year (Figure 2.3). During the Euro Area crisis in 2010-12, EU policy uncertainty may have reduced investment growth in EMDEs in Europe and Central Asia by 0.6-1.3 percentage points with a certain time lag.

- Domestic policy uncertainty. For those EMDEs for which the EPU is available, domestic policy uncertainty also appears to have been accompanied by significantly lower investment: a 10 percent increase in Brazil's EPU may have reduced investment growth by around 0.8 percentage point within a year.

\section{Conclusion}

The post-crisis rise in political and policy uncertainty in most EMDEs has contrasted with a decline in financial market uncertainty amidst benign global financing conditions until late 2016. Low global financial market uncertainty has supported EMDE investment. In contrast, increased policy uncertainty in the EU has significantly reduced investment in EMDEs in Europe and Central Asia. 
Figure 2.1 Evolution of uncertainty in EMDEs

While financial market uncertainty, defined in terms of stock market volatility, has declined in most EMDEs, policy and political uncertainty increased from the pre-crisis to the post-crisis period for most EMDEs. Generally low post-crisis financial market volatility was interrupted by several bouts of global financial market volatility.

\section{A. Share of EMDEs with higher uncertainty in post- crisis than pre-crisis. \\ B. Evolution of uncertainty}
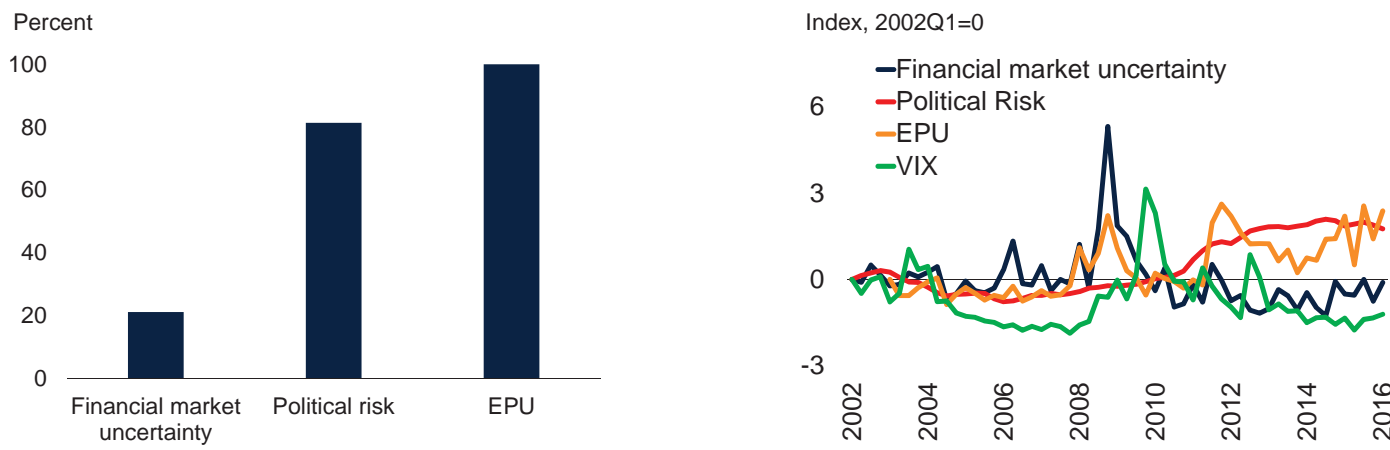

Sources: Baker, Bloom, and Davis (2016); Bloomberg; Haver Analytics; International Country Risk Guide; World Bank estimates.

Notes: 33 countries for measure based on standard deviation of daily stock market changes; 102 countries for ICRG political risk score; and 4 countries (Brazil, China, India, and Russia) for the EPU measure. Financial market uncertainty refers to realized standard deviation of daily changes in stock price changes. Political risk refers to the ICRG political risk index (adjusted such that higher index denotes higher risk).

A. Pre-crisis and post-crisis refer to 2003-08 and 2010-15, respectively. To exclude data for the spike in global financial market uncertainty in the wake of the bankruptcy of Lehman Brothers, pre-crisis average for financial market uncertainty excludes 2008. Last observation is for Q1 2016.

B. All series are normalized to standard deviation of 1 .

\section{Figure 2.2 Financial market uncertainty and investment in EMDEs}

Rising global financial market uncertainty, as captured by the VIX, reduces EMDE investment. Accommodative monetary policy by major central banks has reduced financial market uncertainty.

\section{A. Investment response to a 10 percent increase in the VIX \\ B. Contribution of the VIX to EMDE investment growth}

Percentage points

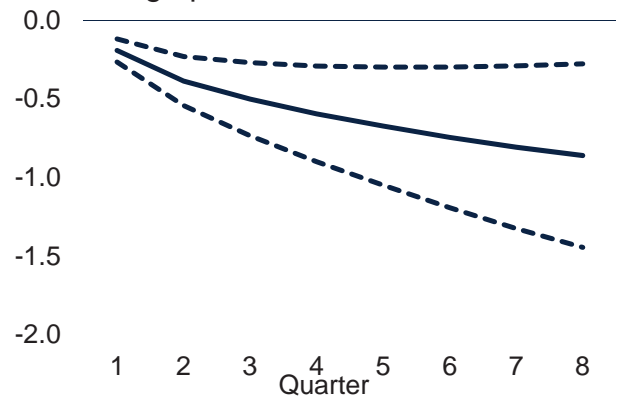

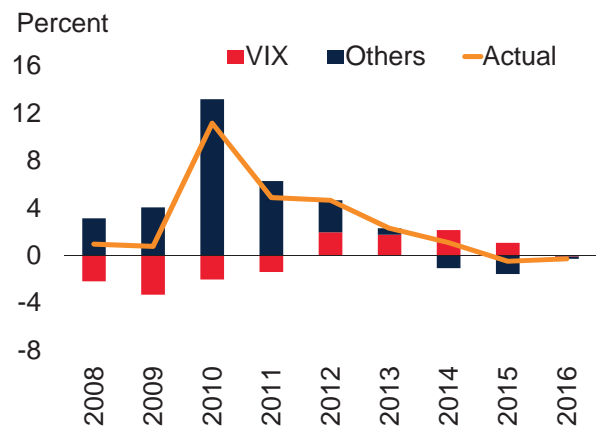

Sources: Bloomberg, Haver Analytics, World Bank estimates.

Note: Vector autoregressions are estimated with sample for 1998Q1-2016Q2. The model includes, in this order, the VIX, MSCI Emerging Markets Index (MXEM), J.P.Morgan Emerging Markets Bond Index (EMBIG), aggregate real output and investment growth in 18 EMDEs with G7 real GDP growth, U.S. 10-year bond yields, and MSCI World Index as exogenous regressors and estimated with two lags. Estimates for 2016 are based on the first half in 2016 (annualized).

A. Shows cumulative responses of EMDE investment to a 10 percent increase in the VIX. Solid lines indicate the median responses and the dotted lines indicate 16-84 percent confidence intervals. B. Indicates historical decomposition to EMDE investment. "Others" indicates other EMDE and global factors, including stock and bond price index. 
Figure 2.3 Policy uncertainty and investment in EMDEs

Elevated policy uncertainty in Europe set back investment in ECA. Policy uncertainty has been a significant cause of the investment slump in Brazil since 2013.

\section{A. ECA investment response to 10 percent increase in EU policy uncertainty}

Percentage points

0.5

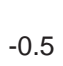

$-1.5$

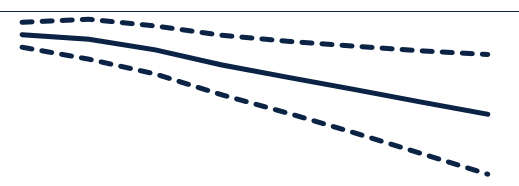

$-2.5$

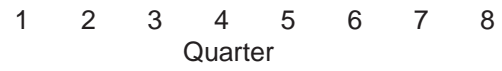

\section{Contribution of EU policy uncertainty to ECA investment growth}

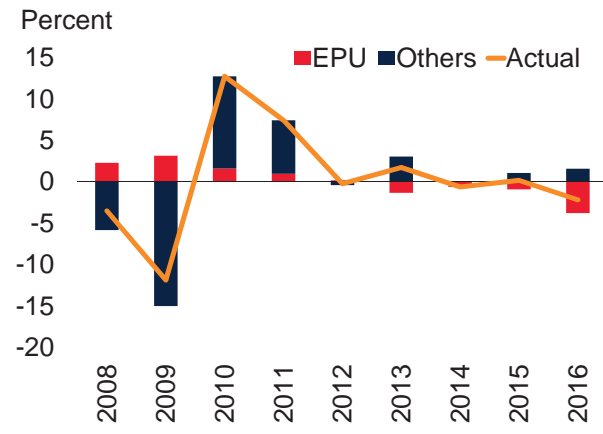

\section{B. Investment response to 10 percent increase in policy uncertainty in Brazil}

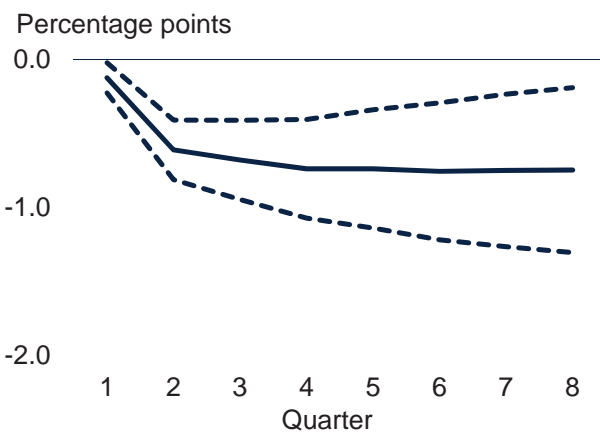

\section{Contribution of domestic policy uncertainty to Brazil's} investment growth

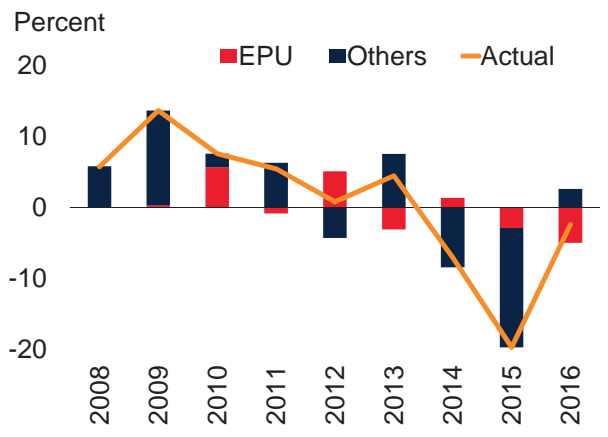

Sources: Bloomberg, Haver Analytics, World Bank estimates.

A.C. Vector autoregressions are used for estimation on a sample of aggregate EMDE variables for 1998Q1-2016Q2. The model includes the EPU for the Euro Area, emerging market stock price (Euro Area) index, emerging market bond index, aggregate real output and investment growth in 6 ECA countries, with G7 real GDP growth, U.S. 10-year bond yields, and MSCI World Index as exogenous regressors and estimated with two lags.

B.D. Country-specific autoregressions are estimated for Brazil for 1998Q1-2016Q2. The model includes the domestic EPU, domestic stock market index, domestic short-term interest rates, and real output and investment growth, with G7 real GDP growth and VIX as exogenous controls and estimated with two lags.

A.B. Show cumulative responses of investment to a 10 percent policy uncertainty shock in the Euro Area and Brazil. Solid lines indicate median responses. Dotted lines indicate the 16-84 percent confidence intervals. Figures $C$. and D. indicate historical decomposition to investment growths in ECA and Brazil, respectively. Estimates for 2016 are based on the first half in 2016 (annualized). 


\section{Appendix 3. Investment Slowdown in China}

Investment growth in China has halved since 2012, in a rebalancing towards more sustainable growth. Private investment growth slowed sharply amidst a policy-driven decline in investment in state-owned enterprises. ${ }^{30}$ Most recently, stimulus-driven infrastructure investment through share-holding enterprises has partly offset a decline in private and SOE investment. Private investment weakness has reflected deteriorating business confidence and weak return prospects. The investment slowdown in China has weighed on output growth in other countries, especially commodity-exporting EMDEs.

China is deeply integrated into the global economy. Its imports account for one-tenth of global imports, its output for more than one-tenth of global output, its investment for one-fifth of global investment, and its investment growth for 42 percent of post-crisis global investment growth (during 2010-15).

A policy-driven rebalancing away from investment- and export-driven growth towards a more sustainable growth model has been underway for several years (Hong et al. 2016). In the process, investment growth in China slowed sharply from a stimulus-driven 21 percent in 2012 to 10 percent in 2015-with global repercussions. ${ }^{31}$ China's investment slowdown accounted for one-third of the slowdown in global as well as EMDE investment growth from 2010 to 2015. Given the role of China in the global economy, it generated sizable adverse spillovers to other EMDEs.

Monthly data available for nominal fixed asset investment (FAI) suggests a further slowdown in 2016: growth in this measure fell to 8 percent (year-on-year) in October 2016 from 21 percent in the year to December 2012, with a sharp shift in composition from the private sector to the publicly controlled sector. FAl by state-owned enterprises or enterprises with majority state participation grew by 20.5 percent (year-on-year) while private investment growth slowed to 2.9 percent (Figure 3.1). ${ }^{32}$ Weak private sector investment adds to concerns about growth prospects as the private sector generates about 65 percent of total investment, around 50 percent of GDP, and 80 percent of employment.

Against this backdrop, this appendix addresses the following questions:

1. How has investment in China evolved since 2010?

2. What has driven the slowdown in China's investment growth?

3. How large are the spillovers from China's investment slowdown?

4. Which policies can support an orderly rebalancing of investment in China?

This appendix documents the slowdown in China's investment growth as well as its shifting composition, with pronounced private sector investment weakness. The slowdown in China's investment growth may

Note: This appendix was prepared by Ekaterine Vashakmadze, Hideaki Matsuoka, and Trang Nguyen, with contributions from Raju Huidrom.

30 Private investment ("minjian" investment) is defined by the Chinese National Bureau of Statistics as the sum of Fixed Asset Investment (FAI) made by enterprises that are registered as collectively-owned, cooperative, private sole proprietorship, private partnership, private limited liability company, business individual, or partnership of business individuals. Private ("minjian") investment also includes FAl by those enterprises in which the above-mentioned entities hold a controlling ownership stake.

${ }^{31}$ Major stimulus was initiated in 2009.

32 In the remainder of this appendix, investment is measured as FAI (in nominal terms), for which monthly data are available. Unlike gross fixed capital formation (in real terms) in the national accounts, it includes purchases of land and other already-owned assets. Real gross fixed capital formation from the national accounts is only available on an annual basis. 
have reduced commodity-exporting EMDEs' growth by about 0.8 percentage point a year, on average, during 2012-15. Policy options to reinvigorate private investment include efforts to facilitate private firm entry and reduce administrative burdens.

\section{Evolution of fixed asset investment since 2010}

Sharp slowdown in investment, shift away from private and SOE investment. Overall investment growth has slowed sharply to 9 percent (year-on-year) in October 2016, from 10 percent at end-2015 and 24 percent in 2010 (Figure 3.1). The slowdown was most pronounced in the private sector. In October 2016, private investment growth slowed to 2.9 percent year-on-year-a steep slowdown from 10.2 percent growth a year earlier and 30 percent in 2012. ${ }^{33}$ Meanwhile, state-owned enterprise (SOE) investment growth also continued to slow to -6 percent (year-on-year) in October 2016 from 12 percent in the previous year. ${ }^{34}$ The slowdowns in SOE and private investment were partly offset by state-supported investment by state-owned enterprises or enterprises with majority state participation.

State-supported investment by state-owned enterprises or enterprises with majority state participation. To stem stock market volatility in August 2015, state-owned companies and government units purchased private company shares on the order of 2 percent of stock market capitalization at end$2015 .{ }^{35}$ As a result, the state became the major or controlling shareholder in companies that previously were not state-controlled. This reclassification of firms in the official data has exaggerated the divergence between SOE, mixed-ownership enterprise, and private investment in 2016 (Lardy and Huang 2016; Kuijs 2016; Coflan 2016). ${ }^{36}$

Broad-based slowdown in private investment growth. The slowdown in private FAl growth since 2010 has been broad-based across all sectors. Private FAI has actually contracted sharply in overcapacity sectors, especially mining and construction. FAl growth has also slowed in the manufacturing sector, as weak export growth and eroding profit margins have discouraged investment spending by private companies. Even in the services sector, after 9.4 percent growth in 2015, private investment growth declined to 2.1 percent (year-on-year) in $2016 \mathrm{H} 1$ and came to a virtual standstill in July 2016 as investment in the transport sector stalled.

\section{Drivers of the investment slowdown}

State-controlled enterprises: Policy-driven cuts in overcapacity. The slowdown in SOE investment growth has partly reflected policy-driven capacity cuts or deleveraging in overcapacity sectors where SOEs predominate (Xing, Sun, and Zheng 2016). Microeconomic policy interventions, especially since 2013,

\footnotetext{
${ }^{33}$ Narrowly defined private investment growth that refers to private enterprises also slowed from 30 percent in 2012 to 9.7 percent in October 2016.

${ }^{34}$ SOE refers to state-controlled or non-corporatized SOEs.

35 The purchase happened in August 2015, but the reclassification started from 2016. The SOE assets reported by SOE jumped in August 2015 (Lardy and Huang 2016).

${ }^{36}$ State investment includes three components: state enterprises, government administrative units, and public institutions. State enterprises include 1) traditional state-owned companies; 2) state-owned companies that have been converted to a corporate form of ownership, typically a limited liability or joint stock company, in which the state is the sole, majority, or dominant owner; 3) companies, including joint ventures, in which the state and a non-state firm or individual each contribute 50 percent of a firm's capital; and 4) consultatively state-controlled companies in which the state capital contribution is less than that of one or more other shareholders but in which the state exercises control by virtue of agreement with the other shareholders or capital contributors. State investment also includes investment by government administrative units and public institutions (Lardy and Huang 2016).
} 
have sharply reduced activity in officially designated "excess capacity" or polluting industries, such as coal and steel production. These cuts are likely to continue in the medium-term. In February 2016, additional capacity reduction targets were announced for coal and steel and a fund was established to re-employ or compensate affected workers. Capacity cuts were accompanied by other measures to strengthen SOE efficiency, including ten pilot programs for SOEs introduced in September 2015 and February 2016. Some provinces began in June 2016 to restructure unviable SOEs.

Private enterprises: Falling returns. Just over a third of the deceleration in private investment growth thus far in 2016 can be attributed to the slowing manufacturing sector ( $Q u$ and Wang 2016). Weakness in manufacturing investment reflects deteriorating business confidence and rising funding costs amid weak return prospects. Slowing export and domestic demand growth and persistent producer price deflation have weighed on return prospects. Between 2011 and 2015, the annual return on investment of private industrial enterprises has been estimated to have fallen by 3 percentage points to 8.5 percent, according to official data. Despite recent efforts to cut red tape, private enterprises still face high entry barriers, sales taxes, and surcharges by comparison with other countries in the region (Ernst and Young 2016).

\section{Spillovers from China's investment growth slowdown}

While the investment growth slowdown is an integral part of ensuring sustainable growth in China in the medium to longer term, it has had significant negative repercussions on activity both domestically, given investment's large share in China's GDP (about 43 percent in 2015), and globally because of China's large role in the global economy. A slowdown in investment spills over to other sectors of the domestic economy through industry and financial linkages. ${ }^{37}$ Since investment is more import-intensive than other components of demand, adverse external spillovers from China's investment slowdown have been particularly pronounced. For example, China imports large volumes of minerals and metals from countries in Latin America and Sub-Saharan Africa (World Bank 2015a, c). Thus, about 40-50 percent of China's import growth slowdown from 2014-15 has been attributed to weak investment (Kang and Liao 2016).

The GDP growth slowdown triggered by an investment slowdown can generate sizable cross-border spillovers (World Bank 2016a; Huidrom, Kose, and Ohnsorge forthcoming). A structural vector autoregression model was estimated for 1998Q1-2016Q2 for 18 EMDEs to assess the magnitude of these spillovers. Details of the estimation are described in Annex 2C.

Since much of investment is resource-intensive, the impact of an investment slowdown on commodityexporting EMDEs is measured to be twice that on commodity-importing EMDEs. A 1 percentage point decline in Chinese annual investment growth reduces output growth in commodity-exporting EMDEs, on average, by 0.3 percentage point over the following year, about one-third the impact of a similarly-sized slowdown in overall output growth in China. In 2012-15, slowing investment growth in China may have reduced commodity-exporting EMDEs' annual output growth by as much as 0.8 percentage point on average (Figure 3.2).

\section{Policies to support an orderly rebalancing of investment}

A slowdown in China's investment growth has been necessary to ensure sustainable growth. However, the concentration of the slowdown thus far in private investment raises concerns about growth prospects.

\footnotetext{
${ }^{37}$ For example, real estate investment in China, which accounts for 25 percent of $\mathrm{FAl}$, has extensive industrial and financial linkages with other sectors of the domestic economy (Ahuja and Nabar 2012a).
} 
Weak private investment lowers prospects for potential output growth, which is already under pressure from a shrinking working-age population and slowing total factor productivity growth. Potential growth is expected to slow from 10.6 percent in 2010 to 6 percent in 2020.

In rebalancing the economy from investment-led towards more sustainable growth, the authorities face two challenges: to sustain private investment growth and to limit adverse spillovers from slowing private investment growth to other parts of the economy. Following an in-depth study in seven provinces, the government announced a range of measures over the past two years. These include efforts to facilitate entry by private firms in a broader range of sectors; and to promote public-private partnerships in activities accounting for 14 percent of 2016 GDP. To ease concerns about the inefficiency of public-private partnerships and limited access for private firms to such projects, the government is drafting regulations to protect private investors in the partnerships. In the short term, this may be complemented by monetary stimulus and tax reductions to encourage private investment.

\section{Conclusion}

A policy-driven slowdown in investment growth has been underway in China since 2012. This has weighed on global output growth, especially in commodity-exporting EMDEs. China's investment slowdown has been accompanied by a particularly sharp decline in investment growth in private enterprises, reflecting deteriorating business confidence and weakening return prospects. The slowdown in private investment raises concerns about potential growth prospects, against the backdrop of an aging population and slowing productivity growth. Policies to rekindle private investment include, in particular, measures to facilitate market access by private firms. 


\section{Figure 3.1. Investment growth in China}

Investment growth has slowed sharply since 2012, especially private investment (or "minjian" investment) growth. The slowdown in private investment growth has been broad-based, with only a modest part explained by data reclassifications. The private investment slowdown reflects deteriorating business confidence and weakening returns prospects, partly as a result of weaker demand prospects but also because of rising impediments to firms' startup and exit, contract enforcement, and tax payments.

\section{A. Fixed asset investment (FAI) growth}

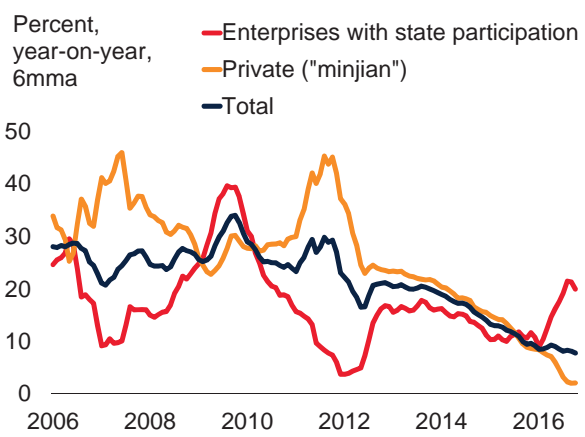

\section{Business confidence}

$$
\begin{array}{ll}
\text { Index } & \text {-Entrepreneurs Confidence } \\
90 & \text {-General Business Confidence } \\
& \text {-Profitability }
\end{array}
$$

80

70

60

50

40

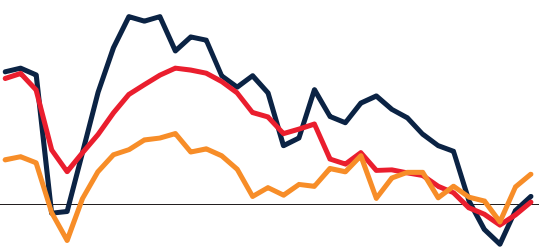

\section{B. Sectoral contribution to private ("minjian") investment growth}

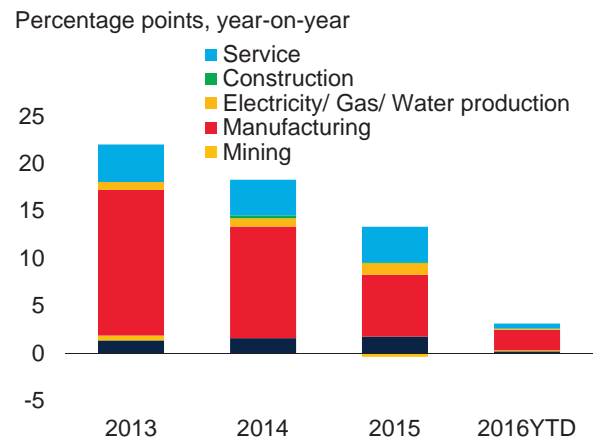

D. Change in doing business' distance to frontier rankings from 2010 to 2016

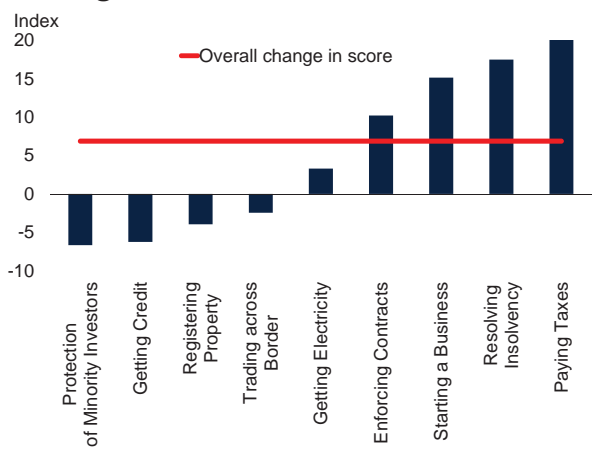

Sources: China Economic and Industry Data Database, China's National Statistical Office, Haver Analytics, The Conference Board, World Bank.

A.B. "Enterprises with state participation" includes enterprises that are state-owned or those with state participation. Investment is defined as fixed assets investment, which differs from gross fixed capital formation in the national accounts by including land sales. Six-month moving averages $(6 \mathrm{mma})$ of year-on-year growth rates. Latest observation is October 2016. See Footnote 30 for the definition of private ("minjian") investment.

C. China industrial enterprise survey of 5000 leading enterprises to rate their perception on selected topics. Index higher than 50 indicates improvement. Latest observation is 2016Q3.

D. Distance of China to the "frontier"-best performers whose score is 100. An increase in scores indicates improvement; a decrease deterioration. 


\section{Figure 3.2. Spillovers from China}

Since investment in China accounts for a large share of domestic output and is import-intensive, its investment growth slowdown has weighed on output growth, both domestically and in other EMDEs.

\section{A. Import intensity of China's investment, exports and consumption, 2014}

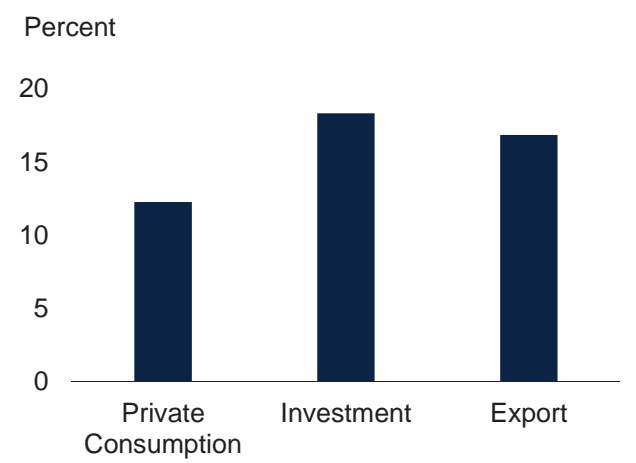

\section{B. Share of investment in China's GDP}

Percent of GDP

60

50

40

30

20

10

0

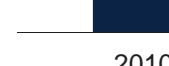

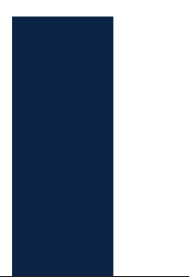

2015

C. Response of EMDE output growth to a decline in China's investment, export and output growth

D. Contribution of China's investment and noninvestment movements to commodity-exporting EMDE growth

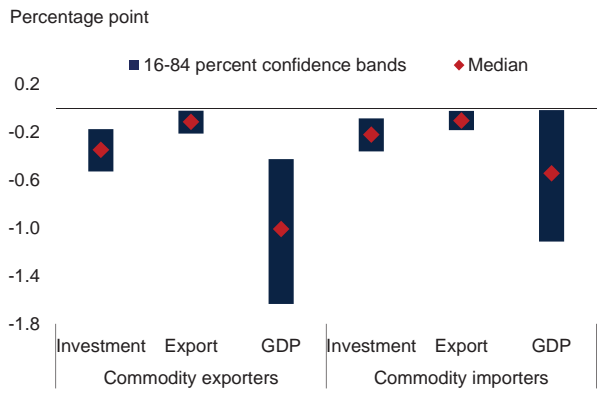

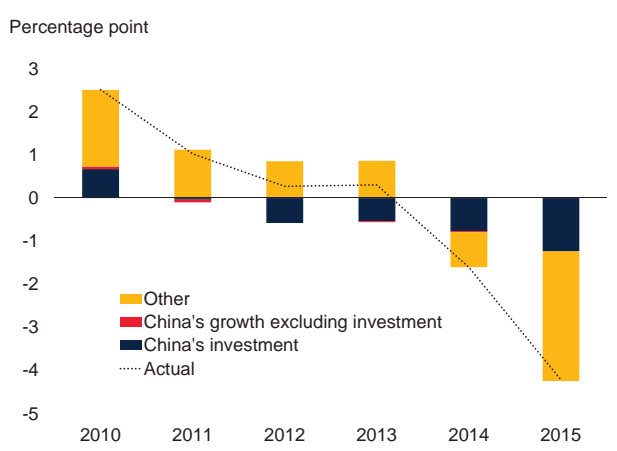

Sources: Haver Analytics, International Monetary Fund, Oxford Economics, World Input Output Database, World Bank estimates.

C. Cumulative impulse response of weighted average EMDE output growth after 1 year to a 1 percentage point decline in growth in real investment, real exports, and real GDP in China. Investment spillovers based on a Bayesian vector autoregression of world GDP growth (excluding China), the U.S. 10-year sovereign bond yield, JP Morgan's EMBI index, growth in the non-investment component of China's real GDP, China's real investment growth, and real GDP growth in the spillover destination group. Oil price is exogenous. Exports and real GDP replace real investment in models that estimate spillovers from exports and output. Sample includes 18 EMDEs from 1998Q1-2016Q2. Blue bars denote 16th-84th percentile confidence interval, red dots denote median of posterior distribution.

D. Historical contribution of China's investment and non-investment growth based on model used for Figure C. Line denotes unweighted average demeaned GDP growth. 


\section{Appendix 4. Interactions between public and private investment}

Both public and private investment have decelerated in EMDEs since the global crisis. Although the effect of public investment on private investment has been mixed, the impact is more likely to be positive in the presence of economic slack, accommodative financial conditions, sizable investment needs, sound institutions, and available skilled labor. The effect on private investment is uneven, but public investment generally does not "crowd out" private investment.

Public investment accounted for 31 percent of total investment in EMDEs and 15 percent of total investment in AEs, on average, over the period 2010-15. Initiatives to boost public investment, including as part of a fiscal stimulus, could therefore directly lift GDP considerably. In addition to this direct effect on activity, public investment has at times proven a catalyst for private investment.

This appendix analyzes recent trends in public and private investment and the effects of public investment on private investment and growth. In particular, it addresses the following questions:

- How have public and private investment evolved since the 2008-09 crisis?

- What are the macroeconomic implications of public investment?

- Which policies can increase the benefits of public investment?

The appendix documents the weakening public and private investment growth in EMDEs. An extensive literature suggests that public investment can significantly raise output and trade and help support better infrastructure. In addition, it is associated with lower income inequality. The evidence on the impact of public investment on private investment, in contrast, is mixed. Policy measures can be implemented to increase the benefits from public investment and mitigate fiscal pressures.

\section{Evolution of public and private investment since the 2008-09 crisis}

Post-crisis public investment slowdown. The fiscal stimulus implemented in many countries in 2008-09 to counter the economic impact of the financial crisis lifted public investment growth above long-term averages in both AEs and EMDEs. In AEs, this boost has subsequently reversed: public investment contracted sharply in 2011, while the cumulative growth rate after 2011 has remained negative (Figure 4.1). In EMDEs, public investment growth also has been weak and has remained below its long-term average, with the exception of 2012. From 2014-15, it began to ease further. This pattern largely reflected sizable initial fiscal stimulus and subsequent policy tightening in large EMDEs, especially China, which accounts for more than half of EMDE public investment.

However, in the majority of EMDEs, public investment growth was below its long-term average throughout 2010-15 (Figure 4.2). In most regions, public investment growth slowed from pre-crisis averages but remained robust above long-term averages in 2008-09. Thereafter, investment growth slowed steadily in all regions, except Sub-Saharan Africa (SSA), to below long-term averages. This slowdown may partly reflect increasing financing constraints as fiscal space eroded following fiscal stimulus during the crisis.

Note: This appendix was prepared by Yoki Okawa. 
Private investment growth slowdown. In AEs, public investment moved broadly counter-cyclically with private investment: surging during the private investment collapse of 2008-09 and contracting in the wake of the crisis as private investment stabilized and began to recover from its deep 2008-09 contraction. A similar pattern occurred in EMDEs during the recession of 2008-09, when surging public investment offset a halving in private investment growth to 7 percent (from 16 percent in 2006-07). After the 2010 rebound, however, private investment growth slowed in synchronization with public investment growth. In more than half of all EMDEs, private investment growth during 2010-15 remained below the long-term average. It was weakest in ECA, mainly as a result of spillovers from the Euro Area crisis, and MENA, where political uncertainty in the wake of the Arab Spring weighed on sentiment.

\section{Macroeconomic implications of public investment}

An extensive literature, summarized in several recent survey papers (Straub 2011; Estache and Garsous 2012; Pereira and Andraz 2013; Bom and Ligthart 2014), has discussed the macroeconomic benefits of public investment. These benefits have included higher growth, more trade, and less income inequality. The effects of public investment on private investment and public finances appear to be more mixed.

Growth. Investment to build public capital lifts growth in AEs, although estimates vary widely. Estimates of the output elasticity of public capital averages 0.14 but ranges from -1.7 for New Zealand to 2.0 for Australia. Estimates of the long-run effect are about three times estimates of the short-run impact. Local government capital generates somewhat higher output gains than central government capital, with considerable cross-regional spillovers (Pereira 2000; Bom and Ligthart 2014). Estimates of the output elasticity of public investment are typically smaller for EMDE than for AEs, possibly reflecting the heterogeneity within the former group (Straub 2011; Kraay 2014). Estimates of the output elasticity of infrastructure capital are somewhat higher than those for general public capital. In EMDEs, the level of infrastructure capital can have a sizable effect on labor productivity. The higher infrastructure capital of upper-middle income EMDEs (relative to lower-income EMDEs) increases output per worker by 5.2 percent in the long run (Calderon et al. 2015).

Links between public and private investment. The impact of public investment on private investment depends on the presence of economic slack, the stances of fiscal and monetary policy, possible financial market reactions, the magnitude of investment needs as well as the institutional and physical environment. Public investment that increases the fiscal deficit in an environment of tight monetary policy, large government debt, and limited economic slack can "crowd out" private investment (Mankiw 2012). Such crowding out has been demonstrated in AEs (Erden and Holcombe 2005) as well as in EMDEs that are not open to trade and financial flows, have weak institutions, or small skilled labor forces (Cavallo and Daude 2011; Warner 2014; Presbitero 2016). In contrast, public investment has been found to "crowd-in" private investment (through positive effects on prospective demand and activity, and increased investor confidence) in some EMDEs, including the lowest-income countries and those with stronger institutional safeguards but sizable infrastructure needs (Cavallo and Daude 2011; Dreger and Reimers 2014; Eden and Kraay 2014; Bahal et al. 2015; Cerra et al. 2016).

Trade. Better public infrastructure, especially trade-facilitating infrastructure, can increase international trade. Improved port and airport facilities and telecommunication quality raise export and import volumes significantly (Nordas and Piermartini 2004; Ismail and Mahyideen 2015). By one estimate, bringing the trade-facilitating infrastructure of below-average member countries of the Asia Pacific Economic 
Cooperation Forum (APEC) to half the APEC average increased intra-APEC trade by about 10 percent (Wilson et al. 2002).

Income inequality. Infrastructure capital and income inequality are negatively correlated in both AEs and EMDEs (Calderon and Serven 2014), although the presence of a causal relationship is still debated. Enhanced public infrastructure may reduce income inequality as well as promote growth if it benefits the poor more than proportionally (Ferreira 1995; Getachew 2010; Fournier and Johansson 2016).

Fiscal space. Increased public expenditure can put pressure on government finances, at least in the shortrun and especially if the government already has a sizable deficit or debt. In the long-run, well-executed high-yielding public investment programs, including in low-income countries, can generate tax revenues that exceed their initial cost, especially if the financing cost is low (Buffie et al. 2012). For AEs with economic slack and accommodative monetary policy, infrastructure investment can also be self-financing over the long-run (Abiad et al. 2015; Holtz-Eakin and Mandel 2015). However, if the productivity of public investment is low, for example because of an already-high stock of public capital, it is likely to leave a longterm legacy of higher debt (Holtz-Eakin and Mandel 2015; ECB 2016).

\section{Policies to increase the benefits of public investment}

Improve efficiency of public investment. The difference between the output and revenue gains associated with public investment and its fiscal cost can be made more favorable by strengthening the efficiency of public investment. Public investment is generally less efficient in EMDEs than in AEs (Albino-War et al. 2014; Dabla-Norris et al. 2012). Its efficiency can be increased in EMDEs through a strategically planned, well-prioritized, rigorous and transparent project selection process and through strengthened institutions to fund, manage, execute, and monitor project implementation (Albino-War et al. 2014; IMF 2015; Rajaram et al. 2010).

Mitigate short-term fiscal pressure. Public investment and public infrastructure investment, in particular, is characterized by large initial expenses that need to be weighed against long-term returns. Even efficient and, over the long-term, self-financing public investment projects may pose short-term fiscal challenges. External financing, especially through concessional loans, can mitigate short-term domestic financing constraints (Buffie et al. 2012). Well-designed public private partnerships, particularly with foreign private sectors, can help reduce fiscal pressure as well. Developing and strengthening a pipeline of infrastructure investment projects can attract investors with lower costs (McKinsey Global Institute 2016).

\section{Conclusion}

Post-crisis, slowing public investment growth in EMDEs has accompanied a steady decline in private investment growth. Public investment can raise output in the short run as well as in the long run, and stimulate trade. Public infrastructure is negatively related to income inequality, although the presence of a causal relationship remains debated. Evidence on the effects of public investment on private investment is mixed. However, public investment is more likely to crowd in private investment in the presence of economic slack, accommodative financial conditions, sizable investment needs, well-developed institutions, and a sufficiently skilled labor force. Improved project selection and monitoring, as well as better governance, may enhance the benefits from public investment. 
Figure 4.1 Public and private investment growth

In AEs, public investment growth has moved broadly counter-cyclically to private investment growth since 2008 . In EMDEs, the counter-cyclical public investment boost of 2008-09 offset a sharp slowdown in private investment growth, but was followed by a period of slowing public and private investment growth. Private investment weakness was most pronounced in BRICS and commodity-exporting EMDEs.

\section{A. Public investment growth}

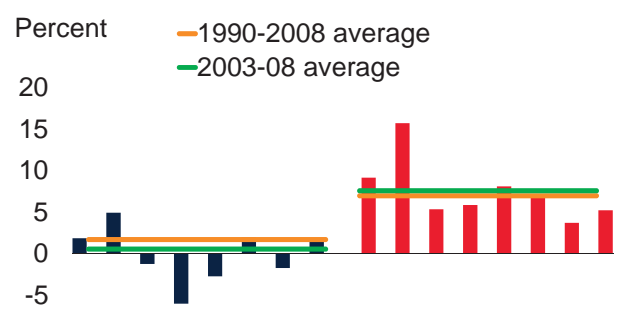

$-10$

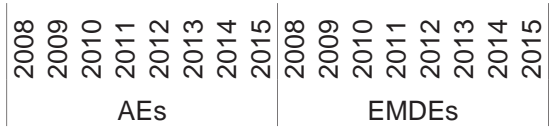

\section{B. Private investment growth}

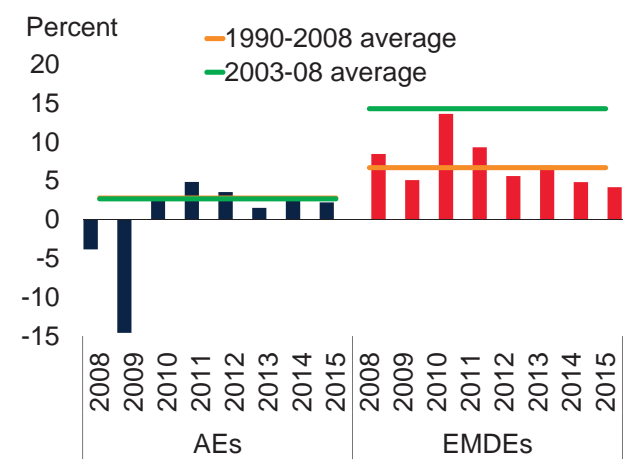

Percentage points

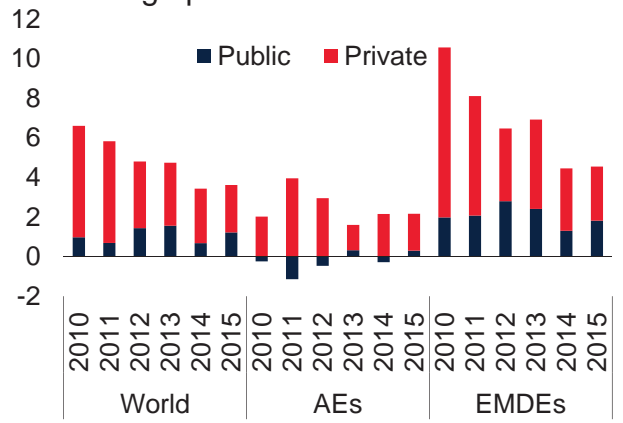

\section{Contributions to investment growth}

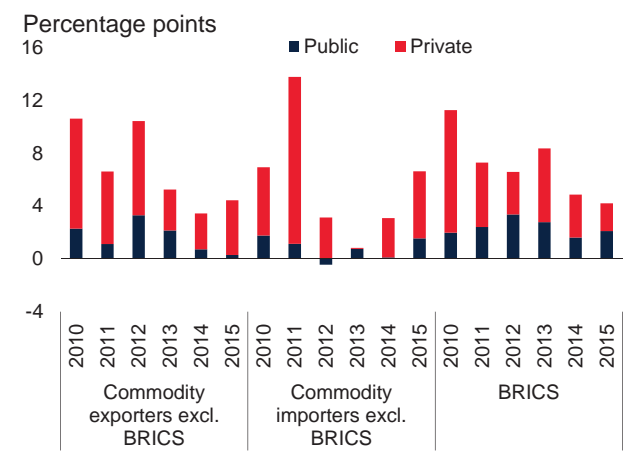

Sources: Eurostat, General Statistics Office of Vietnam, Haver Analytics, International Monetary Fund, Ministry of National Economy of the Republic of Kazakhstan, OECD, Reserve Bank of India, Sri Lanka Ministry of Finance, World Bank. Note: Public and private investment growth rates are weighted average of gross fixed capital formation growth rates in the public and private sectors, respectively, in constant 2005 U.S. dollars. The sample includes 20 advanced economies and 99 EMDEs for 1990 to 2015. 
Figure 4.2 Comparison of public and private investment growth with long-term average

In the majority of EMDEs, both public and private investment growth since 2010 have been below their long-run averages.

\section{A. Countries with public investment growth below 1990-2008 average}

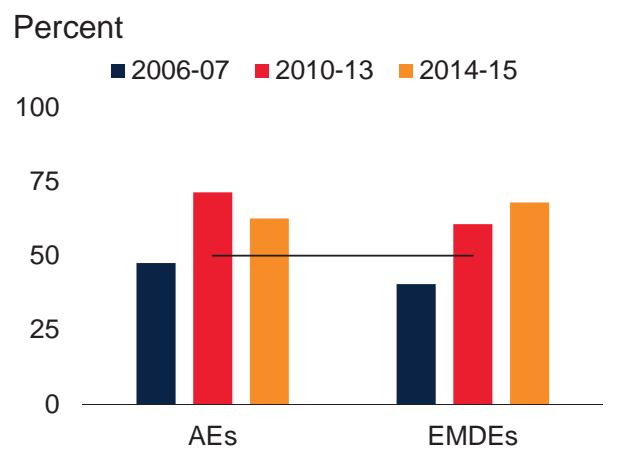

B. Countries with private investment growth below 1990-2008 average

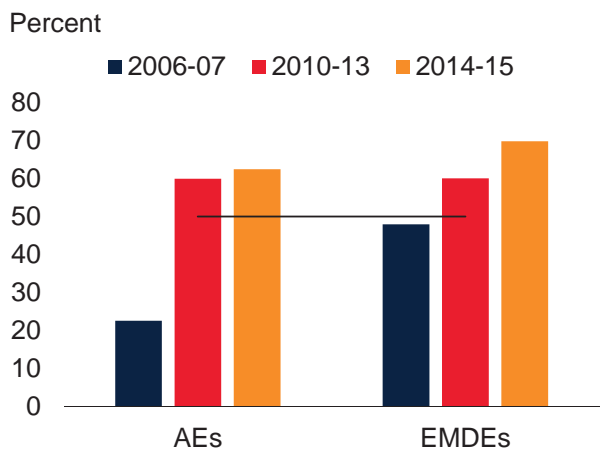

Sources: Eurostat, General Statistics Office of Vietnam, Haver Analytics, International Monetary Fund, Ministry of National Economy of the Republic of Kazakhstan, OECD, Reserve Bank of India, Sri Lanka Ministry of Finance, World Bank.

Note: Public and private investment growth rates are weighted average of gross fixed capital formation growth rates in the public and private sectors, respectively, in constant 2005 U.S. dollars. The sample includes 20 advanced economies and 99 EMDEs for 1990 to 2015. Figures show the share of EMDE and AEs (in percent) in which public and private investment growth was below the 1990-2008 average during the periods specified. Line indicates half of the sample. 


\section{Appendix 5. Macroeconomic implications of foreign direct investment: A brief review.}

This appendix reviews a large literature on the impact of foreign direct investment (FDI) on growth and domestic investment. FDI can boost domestic growth and investment through technology transfers, new managerial practices, new input-output linkages, and easier access to international markets. However, the empirical evidence for the impact of FDI is mixed, as the benefits from FDI are diluted by unskilled labor, weak institutions, lack of financial development, and unfavorable compositions of FDI. The most important benefits of FDI are likely to be collateral ones, such as pressures for improved institutions and macroeconomic stability, that buttress activity more broadly.

\section{Introduction}

FDI can benefit home and host countries alike. By investing abroad, home country firms benefit from greater and more diversified growth opportunities and lower production cost (Herzer and Schrooten 2008; Desai, Foley and Hines 2009). The host country, on the other hand, receives investment, and the technological upgrades that are inherent in investment, and financing (De Mello 1997, Barrell and Pain 1997, Glass and Saggi 2002). FDI is often accompanied by higher infrastructure investment that benefits domestic and foreign firms alike (Alfaro et al. 2004).

This appendix summarizes the findings of an extensive literature to address the following questions. First, what is the impact of FDI on growth in EMDEs? Second, what is the impact of FDI on domestic investment in EMDEs? Third, how can policies help boost FDI and its benefits?

This appendix documents the following findings in the literature. The literature has struggled to establish a causal, positive effect of FDI on growth or investment. The benefits from FDI for growth and investment are most pronounced in the presence of a conducive initial condition. Such initial conditions include a sufficiently skilled labor force that can readily adopt new technologies; a developed financial system that readily finance productive new investment; sound institutions that facilitate firm startup and market entry and exit; and open trade regimes that encourage investment in industries with a comparative advantage. Moreover, greenfield FDI is more likely to generate positive spillovers than mergers and acquisitions and FDI in manufacturing more likely to have beneficial forward and backward linkages. The most important impact of FDI may, however, be collateral benefits that support activity more broadly, such as greater pressure for improved governance, institutions and macroeconomic stability.

\section{What is the impact of FDI on growth in EMDEs?}

Mixed evidence for the impact of FDI on growth. The literature has struggled to establish a causal, positive effect of FDI on growth. This may reflect reverse causality from growth to FDI, third factors driving both FDI and growth, pooling of diverse data, or several offsetting effects of FDI on growth. Several studies have attempted to disentangle the direction of causality and control for a comprehensive set of other factors. Many authors have found no robust causal effect of FDI on growth (Kose et al. 2009; Edison et al. 2002); others have found a causal effect from FDI to growth (Hansen and Rand 2006; Driffield and Jones, 2013); and yet others have found a causal link from growth to FDI (Chowdhury and Mavrotas 2006; Choe 2003). Even for studies that have established a significant impact of FDI on growth, the estimated impact

Note: This appendix was prepared by Mai Anh Bui. 
is positive in some studies (Hansen and Rand 2006; Cipollina et al. 2012; Driffield and Jones, 2013) but negative in others (Herzer 2012; Prasad, Rajan and Subramanian 2007).

Offsetting effects. Offsetting effects could explain the lack of robust evidence for FDI benefiting growth. FDI could promote growth and increase productivity by encouraging technology spillovers (De Mello 1997, Barrell and Pain 1997), strengthening competition (Glass and Saggi 2002), fostering the acquisition of new human capital (Djankov and Hoekman 2000), facilitating access to new export markets (Kneller and Pisu 2007; Kokko, Zejan and Tansini 2001), and introducing new ideas and innovations (Romer 1993). On the other hand, foreign firms may protect their technology or domestic firms may not be in a position to absorb the new technology to benefit from spillovers. In addition, foreign firms that compete with domestic firms in product and factor markets may use fewer domestically produced inputs than the domestic firms they replace (Kose, Prasad, Rogoff and Wei 2009; Görg and Greenaway 2004).

Country-specific initial conditions. As a result of such offsetting effects, the impact of FDI on growth can be highly country-specific. It depends on sectoral differences in FDI and interactions with initial conditions that are necessary to reap the benefits from FDI. Such initial conditions include developed financial markets, strong institutions, an educated workforce, and trade openness:

- Financial development. Countries with well-developed financial markets gain more from FDI since their domestic firms and workers can access financial resources to retool technologies and practices (Alfaro et al. 2004; Azman-Saini, Law and Ahmad 2010; Edison et al. 2002).

- Adequate human capital. Countries with a higher-skilled workforce are better-equipped to absorb the new technology that is brought into the host country by FDI (Bengoa and Sanchez-Robles 2003; Borensztein, Gregorio and Lee 1998)

- Trade openness. If trade is open, FDI is more likely to enter industries in which the host country has a comparative advantage. Activity is likely to be subject to fewer restrictions that could slow the transfer of new technologies to domestic firms (Balasubramanyam, Salisu and Sapsford 1996; Makki and Somwaru 2004; Kohpaiboon 2003)

- Sound institutions. Strong institutions encourage spillovers between FDI and domestic investment. Excessive regulations may discourage the firm startups and exits that may be triggered by FDI or may prevent the allocation of capital to sectors in which FDI is encouraging innovation (Bengoa and Sanchez-Robles 2003, Alguacil, Cuadros and Orts 2011, Driffield and Jones 2013, Busse and Groizard 2008).

- Sectoral composition of FDI. FDI in the primary and services sectors tends to have fewer backward and forward linkages to other domestic sectors and, hence, boost growth less than FDI in the capital-intensive and technologically advanced manufacturing sector (Aykut and Sayek 2005; Cipollina et al. 2012; Chakraborty and Nunnenkamp 2008).

\section{What is the impact of FDI on domestic investment in EMDEs?}

Crowding out or in? Several of the channels that would ensure that FDI lifts growth work through domestic investment. The absorption by domestic firms of the new technology introduced by FDI would stimulate domestic investment, provided financing is available. New forays into export markets by 
domestic firms may require up-front investment. Hence, in addition to directly increasing domestic investment, FDI would have spillovers to domestic investment by domestic firms.

Mixed evidence. Just as for the link between FDI and growth, the literature has struggled to establish a robust empirical link between FDI and domestic investment. Some studies find a positive effect of FDI on domestic investment (Bosworth and Collins 1999; Mody and Murshid 2005; Mileva 2008; Ang 2009; Desai, Foley and Hines 2009) but others find insignificant or mixed effects (Bonfiglioli 2008; Agosin and Machado 2005; Kamaly 2014). The mixed results can be explained by a number of factors:

- Industry linkages versus competitive pressures. FDI in underdeveloped industries may increase demand for inputs from domestic suppliers, thus fostering domestic investment. In contrast, FDI that competes with domestic firms in crowded product markets may drive domestic firms out of business and reduce domestic investment (Arndt, Buch and Schnitzer 2010; Agosin and Machado 2005).

- Greenfield FDI versus mergers and acquisitions. Since mergers \& acquisitions are merely a transfer of ownership of existing production, they may generate fewer benefits to activity than greenfield investment (Mileva 2008; Agosin and Machado 2005).

- Underdeveloped financial markets. Even if FDI invigorates incentives for domestic investment, a lack of funding in underdeveloped markets may prevent such investment (Pels 2010).

- Endogeneity. Empirical studies may be underestimating positive feedback loops from synergies between FDI and domestic investment, where FDI fosters domestic investment which, in turn, signals high returns to investment and encourages further FDI inflows (Ndikumana and Verick 2008).

\section{Conclusion}

FDI inflows to EMDEs have tripled since 2000 and now account for about one-third of global FDI inflows. The literature has found mixed evidence that FDI lifts growth or domestic investment. Weak benefits from FDI may reflect a number of country-specific issues, including the industry composition of FDI inflows, a lack of skilled labor, weak institutions, and underdeveloped financial markets. In addition to these estimates of direct benefits of FDI, FDI may have indirect, productivity-enhancing "collateral" benefits (Kose et al. 2009). These include pressures for better institutions, financial development, and more stabilizing macroeconomic policies.

Policies can be directed at both attracting more FDI and increasing the benefits from FDI inflows. Such policies include investment in human capital to ensure a skilled labor force can readily absorb new technologies. A financial system that allocates capital efficiently can facilitate domestic investment to absorb new technologies. Deeper trade integration can allow FDI to leverage the host country's comparative advantage. Encouraging forward and backward linkages to supplier and distribution networks can accelerate technology transfers. 


\section{References}

Abiad, A., D. Furceri, and P. Topalova. 2015. "The Macroeconomic Effects of Public Investment: Evidence from Advanced Economies." Working Paper 15/95. International Monetary Fund, Washington, DC.

Adhvaryu, A., N. Kala, and A. Nyshadham. 2016. "The Light and the Heat: Productivity Co-benefits of Energy-Saving Technology." Private Enterprise Development in Low-Income Countries (PEDL) Research Note 1775, Department for International Development, London.

Aghion, P., P. Howitt, and F. Murtin. 2011. "The Relationship between Health and Growth: When Lucas Meets Nelson-Phelps." Review of Economics and Institutions 2 (1): 1-24.

Agosin, M., and R. Machado. 2005. "Foreign Investment in Developing Countries: Does it Crowd in Domestic Investment?" Oxford Development Studies 33 (2): 149-162.

Ahuja, A., and M. Nabar. 2012a. "The Spillover Effects of a Downturn in China's Real Estate Investment." Working Paper 12/266, International Monetary Fund, Washington, DC.

Ahuja, A., and M. Nabar. 2012b. "Investment-Led Growth in China: Global Spillovers." Working Paper 12/267, International Monetary Fund, Washington, DC.

Albino-War, M., S. Cerovic, J. C. Flores, K. Javier, H. Qu, Y. Said, and B. Shukurov. 2014. "Making the Most of Public Investment in MENA and CCA Oil-Exporting Countries." IMF Staff Discussion Note. International Monetary Fund, Washington, DC.

Alesina, A., and R. Perotti. 1996. "Income Distribution, Political Instability, and Investment." European Economic Review 40 (6): 1203-1228.

Alfaro, L., A. Chanda, S. Kalemli-Ozcan, and S. Sayek. 2004. "FDI and Economic Growth: The Role of Local Financial Markets." Journal of International Economics 64 (1): 89-112.

Alfaro, L. and E. Hammel. 2007. "Capital Flows and Capital Goods." Journal of International Economics 72 (1): 128-150.

Alguacil M., A. Cuadros, and V. Orts. 2011. "Inward FDI and Growth: The Role of Macroeconomic and Institutional Environment." Journal of Policy Modeling 33: 481-496.

Anand, R. and V. Tulin. 2014. "Disentangling India's Investment Slowdown." Working Paper 14/47, International Monetary Fund, Washington, DC.

Andrews, D., C. Criscuolo, and P. N. Gal. 2015. "Frontier Firms, Technology Diffusion and Public Policy: Micro Evidence from OECD Countries." Productivity Working Paper 2015-02, Organisation for Economic Co-operation and Development, Paris.

Ang, J. 2009. "Do Public Investment and FDI Crowd In or Crowd Out Private Domestic Investment in Malaysia?" Applied Economics 41 (7): 913-919.

Arena, M., S. Bouza, E. Dabla-Norris, K. Gerling, and L. Njie. 2015. "Credit Booms and Macroeconomic Dynamics: Stylized Facts and Lessons for Low-Income Countries." Working Paper 15/11, International Monetary Fund, Washington, DC.

Arndt, C., C. Buch, and M. Schnitzer. 2010. "FDI and Domestic Investment: An Industry-Level View." The B.E. Journal of Economic Analysis and Policy 10 (1): 69.

Aschauer, D. 1989. "Is Public Expenditure Productive?" Journal of Monetary Economics 23 (2): 177-200.

Azman-Saini, W., S. Law, and A. Ahmad. 2010. "FDI and Economic Growth: New Evidence on the Role of Financial Markets." Economics Letters 107 (2): 211-213.

Azzimonti, M. 2016. "The Politics of FDI Expropriation." Working Paper 22705, National Bureau of Economic Research, Cambridge, MA.

Aykut, D., and S. Sayek. 2005. "The Role of the Sectoral Composition of Foreign Direct Investment on 
Growth." (unpublished: Washington, World Bank).

Baffes, J., M. A. Kose, F. Ohnsorge, and M. Stocker. 2015. "The Great Plunge in Oil Prices: Causes, Consequences, and Policy Responses." Policy Research Note 1, World Bank, Washington DC.

Bahal, G., M. Raissi, and V. Tulin. 2015. "Crowding-Out or Crowding-In? Public and Private Investment in India." Working Paper 15/264. International Monetary Fund, Washington, DC.

Bailey, M., J. Manyika, and S. Gupta. 2013. U.S. Productivity Growth: An Optimistic Perspective. Washington, DC: Brookings Institution.

Baker, S., N. Bloom, and S. J. Davis. 2016. "Measuring Economic Policy Uncertainty." Quarterly Journal of Economics 131 (4): 1593-1636.

Baker, S., N. Bloom, B. Canes-Wrone, S. J. Davis, and J. Rodden. 2014. "Why Has U.S. Policy Uncertainty Risen Since 1960?" American Economic Review, Papers \& Proceedings 104 (5): 56-60.

Balasubramanyam, V.N., M. Salisu, and D. Sapsford. 1996. "Foreign Direct Investment and Growth in EP and IS Countries." Economic Journal 106 (434): 92-105.

Banerjee, R., J. Kearns, and M. Lombardi. 2015. "(Why) Is Investment Weak?” BIS Quarterly Review, March. Bank for International Settlements, Geneva.

Barkbu, B., S. P. Berkmen, P. Lukyantsau, S. Saksonovs, and H. Schoelermann. 2015. "Investment in the Euro Area: Why Has It Been Weak?" Working Paper 15/32, International Monetary Fund, Washington, DC. Barrell, R. and N. Pain. 1997. "Foreign Direct Investment, Technological Change, and Economic Growth within Europe." The Economic Journal 107: 1770-1786.

Barro, R. J. 2013. "Health and Economic Growth." Annals of Economics and Finance 14 (2): 329-366.

Barro, R., and J.-W. Lee. 2015. Education Matters: Global Schooling Gains from the 19th to the 21st Century. Oxford: Oxford University Press.

Bengoa, M., and B. Sanchez-Robles. 2003. "Foreign Direct Investment, Economic Freedom and Growth: New Evidence from Latin America." European Journal of Political Economy 19: 529-545.

Blanchard, O. J., and L. Katz. 1999. "Wage Dynamics: Reconciling Theory and Evidence". NBER Working Paper 6924, National Bureau of Economic Research, Boston.

Bloom, D., D. Canning, and J. Sevilla. 2004. "The Effect of Health on Economic Growth: A Production Function Approach." World Development 32 (1): 1-13.

Bloom, N. 2009. "The Impact of Uncertainty Shocks." Econometrica 77 (3): 623-685.

Bloom, N., S. Bond, and J. van Reenen. 2007. "Uncertainty and Investment Dynamics." Review of Economic Studies 74: 391-415.

Bloomfield, P. 2006. "The Challenging Business of Long-Term Public-Private Partnerships: Reflections on Local Experience." Public Administration Review 66 (3): 400-411.

Bom, P. R. D., and J. E. Ligthart. 2014. "What Have We Learned From Three Decades of Research on the Productivity of Public Capital?" Journal of Economic Surveys 28 (5): 889-916.

Bonfiglioli, A. 2008. "Financial Integration, Productivity and Capital Accumulation." Journal of International Economics 76 (2): 337-355.

Borensztein, E., J. D. Gregorio, and J.-W. Lee. 1998. "How Does Foreign Direct Investment Affect Growth?" Journal of International Economics 45 (1): 115-135.

Borio, C., E. Karroubi, C. Upper, and F. Zampolli. 2015. "Labour Reallocation and Productivity Dynamics: Financial Causes, Real Consequences." BIS Working Papers 534. Bank for International Settlements, Basel. Bosworth, B. P., and S.M. Collins. 1999. "Capital Flows to Developing Economies: Implications for Saving 
and Investment." Brookings Papers on Economic Activity 1: 143-180. Brookings Institution, Washington, DC.

Bourreaua, M., C. Cambinib, and P. Doğanc. 2012. "Access Pricing, Competition, and Incentives to Migrate from 'Old' to 'New' Technology." International Journal of Industrial Organization 30 (6): 713-723.

Brynjolfsson, E., and A. McAfee. 2011. Race Against the Machine: How the Digital Revolution is Accelerating Innovation, Driving Productivity, and Irreversibly Transforming Employment and the Economy. Lexington: Digital Frontier Press.

Buffie, E. F., A. Berg, C. Pattillo, R. Portillo, and L-F. Zanna. 2012. "Public Investment, Growth, and Debt Sustainability: Putting Together the Pieces." Working Paper 12/144. International Monetary Fund, Washington, DC.

Busse, M., and J. L. Groizard. 2008. "Foreign Direct Investment, Regulations and Growth." The World Economy 31: 861-886.

Bussiere, M., L. Ferrara, and J. Milovich. 2016. "Explaining the Recent Slump in Investment: The Role of Expected Demand and Uncertainty." IMF Research Bulletin 17 (1): 1-3.

Bussolo, M., J. Koettl, and E. Sinnott. 2015. Golden Aging: Prospects for Healthy, Active, and Prosperous Aging in Europe and Central Asia. Washington, DC: World Bank.

Calcagnini, G., A. Ferrando, and G. Giombini. 2015. "Multiple Market Imperfections, Firm Profitability and Investment." European Journal of Law and Economics 40 (1): 95-120.

Calderón, C., and L. Servén. 2014. "Infrastructure, Growth, and Inequality: An Overview." Policy Research Working Paper 7034. World Bank, Washington, DC.

Calderón, C., E. Moral-Benito, and L. Servén. 2015. "Is Infrastructure Capital Productive? A Dynamic Heterogeneous Approach." Journal of Applied Econometrics 30 (2): 177-98.

Carrière-Swallow, Y., and L. F. Céspedes. 2013. "The Impact of Uncertainty Shocks in Emerging Economies." Journal of International Economics 90 (2): 316-325.

Caselli, F. 2005. "Chapter 9 Accounting for Cross-Country Income Differences." Handbook of Economic Growth, Vol 1(A): 679-741.

Caselli, F., P. Pagano, and F. Schivardi. 2003. "Uncertainty and the Slowdown in Capital Accumulation in Europe." Applied Economics 35: 79-89.

Cavallo, E., and C. Daude. 2011. "Public Investment in Developing Countries: A Blessing or a Curse?" Journal of Comparative Economics 39 (1): 65-81.

Cerra, V., A. Cuevas, C. Goes, I. Karpowicz, T. Matheson, I. Samake, and S. Vtyurina. 2016. "Highways to Heaven: Infrastructure Determinants and Trends in Latin America and the Caribbean." Working Paper 16/185, International Monetary Fund, Washington, DC.

Chakraborty, C. and P. Nunnenkamp. 2008. "Economic Reforms, FDI and its Economic Effects in India: A Sector Level Analysis." World Development 36 (7): 1192-1212.

Chinn, M. D. 2014. “Central Banking: Perspectives from Emerging Economies.” La Follette School of Public Affairs Working Paper Series, No. 2014-006.

Choe, J.I. 2003. "Do Foreign Direct Investment and Gross Domestic Investment Promote Economic Growth?" Review of Development Economics 7 (1): 44-57.

Chowdhury, A., and G. Mavrotas. 2006. "FDI and Growth: What Causes What?" World Economy 29 (1): 919.

Cipollina, M., G. Giovannetti, F. Pietrovito, and A.F. Pozzolo. 2012. "FDI and Growth: What Cross-country Industry Data Say." The World Economy 35: 1599-1629. 
Citigroup. 2016. "Urbanization: A Major Driver of Infrastructure Spending." Citigroup, New York.

Coflan, A. 2016. "China's State Investment Surge: Stimulus or Statistics?" Rhodium Group Research. http://rhg.com/notes/chinas-state-investmentsurge-stimulus-or-statistics.

Colecchia, A., and P. Schreyer. 2002. "ICT Investment and Economic Growth in the 1990s: Is the United States a Unique Case? A Comparative Study of Nine OECD Countries." Review of Economics Dynamics 5 (2): 408-442.

Comin, D., and M. M. Ferrer. 2013. "If Technology Has Arrived Everywhere, Why Has Income Diverged?" Working Paper 19010, National Bureau of Economic Research, Cambridge, MA.

Constantinescu, C., A. Mattoo, and M. Ruta. 2015. "The Global Trade Slowdown: Cyclical or Structural?" Working Paper 15/6, International Monetary Fund, Washington, DC.

Constantinescu, C., A. Mattoo, and M. Ruta. 2016. "Does the Global Trade Slowdown Matter?" Policy Research Working Paper 7673, World Bank, Washington, DC.

Corcoran, A., and R. Gillanders. 2015. "Foreign Direct Investment and the Ease of Doing Business." Review of World Economics 151 (1): 103-26.

Cowen, T. 2011. The Great Stagnation: How America Ate All the Low-Hanging Fruit of Modern History, Got Sick, and Will (Eventually) Feel Better. New York: Dutton.

Czernich, N., O. Falck, T. Kretschmer, and L. Woessmann. 2011. "Broadband Infrastructure and Economic Growth." The Economic Journal 121: 505-532.

Dabla-Norris, E., J. Brumby, A. Kyobe, Z. Mills, and C. Papageorgiou. 2012. "Investing in Public Investment: An Index of Public Investment Efficiency." Journal of Economic Growth 17 (3): 235-66.

Dasgupta, B., L. Somik, and N. Lozano-Gracia. 2014. "Urbanization and Housing Investment." World Bank Policy Research Paper 7110, World Bank, Washington, DC.

De Mello, L. 1997. "Foreign Direct Investment in Developing Countries and Growth: A Selective Survey." Journal of Development Studies 34 (1): 1-34.

Desai, M. A., F. Foley, and R. Hines. 2009. "Domestic Effects of the Foreign Activities of US Multinationals." American Economic Journal: Economic Policy 1 (1): 181-203.

Didier, T., M. A. Kose, F. Ohnsorge, and L. S. Ye. 2015. "Slowdown in Emerging Markets: Rough Patch or Prolonged Weakness?" Policy Research Note 4, World Bank, Washington, DC.

Djankov, S. and B. Hoekman. 2000. "Foreign Investment and Productivity Growth in Czech Enterprises." World Bank Economic Review 14 (1): 49-64.

Dreger, C., and H. Reimers. 2014. "On the Relationship between Public and Private Investment in the Euro Area." DIW Berlin Discussion Papers 1365. Berlin, Germany.

Driffield, N., and C. Jones. 2013. "Impact of FDI, ODA and Migrant Remittances on Economic Growth in Developing Countries: A Systems Approach." European Journal of Development Research 25: 173-196.

ECB (European Central Bank). 2016. "Public Investment in Europe." ECB Economic Bulletin (2): 1-14. European Central Bank, Frankfurt.

Eden, M., and A. Kraay. 2014. "Crowding in and the Returns to Government Investment in Low Income Countries." Development Research Group Working Paper 6781. World Bank, Washington, DC.

Edison, H., R. Levine, L. Ricci, and T. Slok. 2002. "International Financial Integration and Economic Growth." Journal of International Monetary and Finance 21 (6): 749-76.

Elekdag, S., and Y. Wu. 2013. "Rapid Credit Growth in Emerging Markets: Boon or Boom-Bust?" Emerging Markets Finance and Trade 49 (5): 45-62. 
Erden, L., and R. G. Holcombe. 2005. "The Effects of Public Investment on Private Investment in Developing Economies." Public Finance Review 33 (5): 575-602.

Ernst \& Young. 2016. Worldwide Corporate Tax Guide. London: Ernst \& Young.

Estache, A., and G. Garsous. 2012. "The Impact of Infrastructure on Growth in Developing Countries." IFC Economics Notes. 1. International Finance Corporation, Washington, DC.

Everhart S., J. Martinez-Vazquez, and R. M. McNab. 2009. "Corruption, Governance, Investment and Growth in Emerging Markets." Applied Economics 41 (13): 1579-1594.

Feldstein, M. 2008. "Did Wages Reflect Growth in Productivity?" NBER Working Paper 13953, National Bureau of Economic Research, Cambridge, MA.

Fernald, J. G. 1999. "Roads to Prosperity? Assessing the Link between Public Capital and Productivity." American Economic Review 89 (3): 619-638.

Ferreira, F. H. G. 1995. "Wealth Distribution Dynamics with Public-Private Capital Complimentarity." Discussion Paper TE/95/286. London School of Economics and Political Science, London.

Field, E. 2005. "Property Rights and Investment in Urban Slums." Journal of the European Economic Association 3 (2-3): 279-290.

Fournier, J.-M., and A. Johansson. 2016. "The Effect of the Size and the Mix of Public Spending on Growth and Inequality." Economics Department Working Paper 1344. Organisation for Economic Co-operation and Development, Paris.

Freund, C. 2016. "The Global Trade Slowdown and Secular Stagnation." Peterson Institute of International Economics blog. https://piie.com/blogs/trade-investment-policy-watch/global-tradeslowdown-andsecular-stagnation.

G20. 2015. G20/OECD Report on G20 Investment Strategies. Vol 2. Organisation for Economic Cooperation and Development, Paris.

. 2016a. "Developments in Investment and Policy Challenges." Paper for G-20, June. Organisation for Economic Co-operation and Development, Paris.

. 2016b. G20 Leaders' Communique, Hangzhou Summit, Sept 4-5.

Getachew, Y. Y. 2010. "Public Capital and Distributional Dynamics in a Two-Sector Growth Model." Journal of Macroeconomics 32 (2): 606-16.

Gilchrist, S., J. Sim, and E. Zakrajsek. 2014. "Uncertainty, Financial Frictions, and Investment Dynamics." Working Paper 20038, National Bureau of Economic Research, Cambridge, MA.

Glaeser, E. L. 2008. Cities, Agglomeration and Spatial Equilibrium. Oxford: Oxford University Press.

Glass, A. J., and K. Saggi. 2002. "Multinational Firms and Technology Transfer." Scandinavian Journal of Economics 104: 495-513.

Gollop, F. M., B. M. Fraumeni, and D. W. Jorgenson. 1987. Productivity and U.S. Economic Growth. Cambridge: Harvard University Press.

Gordon, R. J. 2012. "Is U.S. Economic Growth Over? Faltering Innovation Confronts the Six Headwinds." Working Paper 18315. National Bureau of Economic Research, Cambridge, MA.

Gorg, H., and D. Greenaway. 2004. "Much Ado about Nothing? Do Domestic Firms Really Benefit from Foreign Direct Investment?" World Bank Research Observer 19 (2): 171-97.

Griliches, Z. 1988. "Productivity Puzzles and R \& D: Another Nonexplanation." Journal of Economic Perspectives 2 (4): 9-21.

Hall, R.E., and C. Jones. 1999. "Economic Growth: A Review Essay." The Quarterly Journal of Economics 114 (1): 83-116. 
Hall, R.E., and D.W. Jorgenson. 1967. "Tax Policy and Investment Behavior." American Economic Review 57 (3): 391-414.

Hall, R.E. 2016. "Macroeconomics of Persistent Slumps." NBER Working Paper 22230. National Bureau of Economic Research, Cambridge, MA.

Hansen, H. and J. Rand. 2006. "On the Causal Links between FDI and Growth in Developing Countries." The World Economy 29 (1): 21-41.

Hennessy, C. 2004. “Tobin's Q, Debt Overhang, and Investment.” Journal of Finance 59 (4): 1717-1742.

Herrera, S., and G. Pang. 2005. Efficiency of Public Spending In Developing Countries: An Efficiency Frontier Approach. Washington, DC: World Bank.

Herzer, D., and M. Schrooten. 2008. "Outward FDI and Domestic Investment in Two Industrialized Countries." Economics Letters 99 (1): 139-143.

Herzer, D. 2012. “How Does Foreign Direct Investment Really Affect Developing Countries' Growth?" Review of International Economics 20: 396-414.

Holtz-Eakin, D., and M. Mandel. 2015. "Dynamic Scoring and Infrastructure Spending." McGraw Hill Financial Global Institute, New York.

Hong, G.H., J. Lee, W. Liao, and D. Seneviratne. 2016. "China and Asian Global Trade Slowdown." Working Paper 16/105, International Monetary Fund, Washington, DC.

Hsieh, C.-T. and P. Klenow. 2010. "Development Accounting." American Economic Journal: Macroeconomics 2: 207-223.

Huidrom, R., M.A. Kose, and F. Ohnsorge. Forthcoming. "Spillovers from Major Emerging Markets." Mimeo, World Bank, Washington, DC.

IFC (International Finance Corporation). 2016a. "Global Productivity Slowdown and the Role of Technology Adoption in Emerging Markets." Note 6, EMCompass. International Finance Corporation, Washington, DC.

IFC (International Financial Corporation). 2016b. "A New Look at the Determinants of Investment in Emerging Markets." Mimeo, Sept. 30. International Finance Corporation, Washington, DC.

IMF (International Monetary Fund). 2015a. "Private Investment: What's the Holdup?" Chapter 4, World Economic Outlook, April. Washington, DC: International Monetary Fund.

2015b. People's Republic of China: Staff Report for the 2015 Article IV Consultation. Washington, DC: International Monetary Fund.

. 2016. "Global Trade: What's Behind the Slowdown?" Chapter 2, World Economic Outlook, October. Washington, DC: International Monetary Fund.

Inderst, G. 2016. "Infrastructure Investment, Private Finance, and Institutional Investors: Asia from a Global Perspective." ADBI Working Paper 555. Asian Development Bank, Manila.

International Energy Agency. 2014. World Energy Investment Outlook-Special Report, Paris: International Energy Agency.

Ismail, N. W., and J. M. Mahyideen. 2015. "The Impact of Infrastructure on Trade and Economic Growth in Selected Economies in Asia." Working Paper Series 553, Asian Development Bank Institute, Manila.

Jones, C. 2003. "Human Capital, Ideas, and Economic Growth." In Finance, Research, Education, and Growth, edited by L. Paganetto, and E. Phelps. London: Palgrave McMillian.

Jorgenson, D. 1963. "Capital Theory and Investment Behavior." American Economic Review 53 (2): 247259.

1991. "Productivity and Economic Growth," In Fifty Years of Economic Measurement: The Jubilee 
of the Conference on Research in Income and Wealth. National Bureau of Economic Research, Cambridge, MA.

Jorgenson, D., and C. D. Siebert. 1968. "Optimal Capital Accumulation and Corporate Investment Behavior." Journal of Political Economy 76 (6): 1123-1151.

Julio, B., and Y. Yook. 2012. "Political Uncertainty and Corporate Investment Cycles." Journal of Finance 67 (1): 45-83.

Jurado, K., S. Ludvigson, and S. Ng. 2015. "Measuring Uncertainty." American Economic Review 105 (3): 1177-1216.

Kalemli-Ozcan, S., L. Laeven, and D. Moreno. 2015. “Debt Overhang in Europe: Evidence from Firm-BankSovereign Linkages." Unpublished paper, University of Maryland.

Kamaly, A. 2014. "Does FDI Crowd in or out Domestic Investment? New Evidence from Emerging Economies." Modern Economy 5: 391-400.

Kang, J.S., and W. Liao. 2016. "Chinese Imports: What's Behind the Slowdown?" Working Paper 16/106, International Monetary Fund, Washington, DC.

Keefer, P. and S. Knack. 2007. "Boondoggles, Rent-Seeking, and Political Checks and Balances: Public Investment under Unaccountable Governments." The Review of Economics and Statistics 89 (3): 566-572.

Kessides, I. 2004. "Reforming Infrastructure: Privatization, Regulation, and Competition." Policy Research Report, World Bank, Washington, DC.

Klenow, P., and A. Rodríguez-Clare. 1997. "Economic Growth: A Review Essay." Journal of Monetary Economics 40: 597-618.

Kneller, R., and M. Pisu. 2007. "Industrial Linkages and Export Spillovers from FDI." The World Economy 30 (1): 105-134.

Kohpaiboon, A. 2003. "Foreign Trade Regimes and the FDI-Growth Nexus: A Case Study of Thailand." Journal of Development Studies 40 (2): 55-69.

Kokko, A., M. Zejan, and R. Tansini. 2001. "Trade Regimes and Spillover Effects of FDI: Evidence from Uruguay." Weltwirtschaftliches Archiv 137 (1): 124-149.

Kothari, S. P., J. Lewellen, and J. B. Warner. 2015. "The Behavior of Aggregate Corporate Investment." MIT Sloan Research Paper 5112-14, MIT, Cambridge.

Kose, M. A., and M. Terrones. 2015. Collapse and Revival: Understanding Global Recessions and Recoveries. Washington, DC: International Monetary Fund.

Kose, M. A., E. Prasad, K. Rogoff, and S. Wei. 2009. "Financial Globalization: A Reappraisal." IMF Staff Papers 56 (1): 8-62.

Kose, M. A., S. Kurlat, F. Ohnsorge, and N. Sugawara. Forthcoming. "A Cross-Country Database of Fiscal Space." World Bank Policy Research Working Paper. World Bank, Washington, DC.

Kraay, A. 2014. "Government Spending Multipliers in Developing Countries: Evidence from Lending by Official Creditors." American Economic Journal: Macroeconomics 6 (4): 170-208.

Kuijs, L. 2016. "Credit and Investment -Problems and Misunderstandings." Research Briefing-China, Oxford Economics.

Lamont, O. 2002. "Macroeconomic Forecasts and Microeconomic Forecasters." Journal of Economic Behavior \& Organization 48 (3): 265-280.

Lardy, N. R., and Z. Huang. 2016. "China Private Investment Softens, But Not as Much as Official Data Suggest." Peterson Institute for International Economics, Washington, DC. https://piie.com/blogs/chinaeconomic-watch/china-private-investment-softens-not-muchofficial-data-suggest. 
Leboeuf, M., and B. Fay. 2016. "What Is Behind the Weakness in Global Investment?" Staff Discussion Paper 5, Bank of Canada, Ottawa.

Lewis, C., N. Pain, J. Strasky, and F. Menkyna. 2014. "Investment Gaps after the Crisis." Economics Department Working Paper 1168, Organisation for Economic Co-operation and Development, Paris.

Li, D., N. Magud, and F. Valencia. 2015. "Corporate Investment in Emerging Markets: Financing vs. Real Options Channel." Working Paper 15/285, International Monetary Fund, Washington, DC.

Lim, J. 2014. "Institutional and Structural Determinants of Investment Worldwide." Journal of Macroeconomics 41 (C): 160-177.

Magud, N., and S. Sosa. 2015. "Investment in Emerging Markets. We Are Not in Kansas Anymore...Or Are We?" Working Paper 15/77, International Monetary Fund, Washington DC.

Makki, S., and A. Somwaru. 2004. "Impact of Foreign Direct Investment and Trade on Economic Growth: Evidence from Developing Countries." American Journal of Agricultural Economics 86: 795-801.

Mandl, U., A. Dierx, and F. Ilzkovitz. 2008. "The Effectiveness and Efficiency of Public Spending." European Economy Economic Papers 301. European Commission, Brussels.

Mankiw, N. G. 2012. Macroeconomics. New York: Worth Publishers.

Mauro, P. 1995. "Corruption and Growth." The Quarterly Journal of Economics 110 (3): 681-712.

McGowan, M. A., and D. Andrews. 2015. "Labour Market Mismatch and Labour Productivity: Evidence from PIAAC Data." Economics Department Working Paper 1209, Organisation for Economic Co-operation and Development, Paris.

McKinsey \& Company. 2016. "Bridging Global Infrastructure Gaps." McKinsey \& Company, Brussels.

McQuade, P., and M. Schmitz. 2016. "The Great Moderation in International Capital Flows: a Global Phenomenon?" ECB Working Paper 1952, European Central Bank, Frankfurt.

Melzer, Brian. Forthcoming. "Mortgage Debt Overhang: Reduced Investment by Homeowners at Risk of Default." Journal of Finance.

Mendoza, E., and M. E. Terrones. 2012. "An Anatomy of Credits Booms and their Demise." Journal Economia Chilena 15 (2): 04-32.

Mileva, E. 2008. "The Impact of Capital Flows on Domestic Investment in Transition Economies." Working Paper Series 0871. European Central Bank.

Mishra, P., P. Montiel, P. Pedroni, and A. Spilimbergo. 2014. "Monetary Policy and Bank Lending Rates in Low-income Countries: Heterogeneous Panel Estimates." Journal of Development Economics 111: 117131.

Mody, A., and A. P. Murshid. 2005. "Growing Up with Capital Flows." Journal of International Economics 65 (1): 249-266.

Montenegro, C. E., and H. A. Patrinos. 2014. "Comparable Estimates of Returns to Schooling Around the World." Policy Research Working Paper 7020, World Bank, Washington, DC.

Morrissey, O., and M. Udomkerdmongkol. 2012. "Governance, Private Investment and Foreign Direct Investment in Developing Countries." World Development 40 (3): 437-445.

Munemo, J. 2014. "Business Start-Up Regulations and the Complementarity Between Foreign and Domestic Investment." Review of World Economics 150 (4): 745-61.

Myers, S. 1977. "Determinants of Corporate Borrowing." Journal of Financial Economics 5: 147-175.

Mutreja, P., B. Ravikumar, and M. J. Sposi. 2014. "Capital Goods Trade and Economic Development." Working Paper 2014-012B, Federal Reserve Bank of St. Louis.

Nabar, N., and J. Joyce. 2009. "Sudden Stops, Banking Crises, and Investment Collapses." Journal of 
Development Economics 90 (2): 163-189.

Naumov, A. 2016. "Global Investment - The Role of Emerging Markets." Bank Underground, Bank of England, September 23. https://bankunderground.co.uk/2016/09/23/globalinvestment-the-role-ofemerging-markets/.

Ndikumana, L., and S. Verick. 2008. "The Linkages Between FDI and Domestic Investment: Unravelling the Developmental Impact of Foreign Investment in Sub-Saharan Africa." Development Policy Review 26 (6): 713-726.

Nordås, H. K., and R. Piermartini. 2004. "Infrastructure and Trade." WTO Staff Working Paper ERSD-200404, World Trade Organization, Geneva.

Occhino, F. and A. Pescatori. 2010. "Debt Overhang and Credit Risk in a Business Cycle Model." Working Paper 1003, Federal Reserve Bank of Cleveland, Cleveland.

OECD (Organisation for Economic Co-operation and Development). 2015a. "Lifting Investment for Higher Sustainable Growth." OECD Economic Outlook, 1: 205-279.

. 2015b. Mapping Channels to Mobilise Institutional Investment in Sustainable Energy. Green Finance and Investment Series. Paris: Organisation for Economic Co-operation and Development.

2016a. Compendium of Productivity Indicators 2016. Paris: Organisation for Economic Cooperation and Development.

2016b. "Global Growth Warning: Weak Trade, Financial Distortions." Interim Economic Outlook, September. Organisation for Economic Co-operation and Development, Paris.

. 2016c. "Using the Fiscal Levers to Escape the Low-Growth Trap." Chapter 2, OECD Economic Outlook, Organisation for Economic Co-operation and Development, Paris.

Ohnsorge, F., and S. Yu. 2016. "Recent Credit Surge in Historical Context." Policy Research Working Paper 7704, World Bank, Washington, DC.

Ollivaud, P., Y. Guillemette, and D. Turner. 2016. "Links Between Weak Investment and the Slowdown in Productivity and Potential Output Growth Across the OECD." Working Paper 1304. Organisation for Economic Co-operation and Development, Paris.

Pang, G., and S. Herrera. 2005. "Efficiency of Public Spending in Developing Countries: An Efficiency Frontier Approach." Policy Research Working Paper 3645. World Bank, Washington, DC.

Pels. 2010. "Capital Inflows and Investment." The Institute for International Integration Studies Discussion Paper Series 330.

Pereira, A. M. 2000. "Is All Public Capital Created Equal?" Review of Economics and Statistics 82 (3): $513-$ 18.

Pereira, A. M., and J. M. Andraz. 2013. "On the Economic Effects of Public Infrastructure Investment: A Survey of the International Evidence." College of William and Mary Department of Economics Working Paper 108. Williamsburg, VA.

Petri, P., and M. Plummer. 2016. "The Economic Effects of the Trans-Pacific Partnership: New Estimates." Working Paper 16-2, Peterson Institute for International Economics, Washington, DC.

Pongsiri, N. 2002. "Regulation and Public-Private Partnerships." International Journal of Public Sector Management 15 (6): $487-495$.

Prasad, E., R. Rajan, and A. Subramanian. 2007. "Foreign Capital and Economic Growth." Brookings Papers on Economic Activity 38(1): 153-230. The Brookings Institution, Washington, DC.

Presbitero, A. F. 2016. "Too Much and Too Fast? Public Investment Scaling-up and Absorptive Capacity." Journal of Development Economics 120: 17-31. 
Qu, H., and J. Wang. 2016. "China: Why is Private Investment Still Slowing?" In Asian Economics Quarterly Report 19-24. HSBC Global Research, Hong Kong SAR, China.

Qureshi, Z., J. L. Diaz-Sanchez, and A. Varoudakis. 2015. "The Post-Crisis Growth Slowdown in Emerging Economies and the Role of Structural Reforms." Global Journal of Emerging Market Economies 7 (2): 179200.

Rajaram, A., T. M. Le, N. Biletska, and J. Brumby. 2010. "A Diagnostic Framework for Assessing Public Investment Management." Policy Research Working Paper 5397, World Bank, Washington, DC.

Reinikka, R., and J. Svensson. 2002. "Coping with Poor Public Capital." Journal of Development Economics 69: 51-69.

Romer, P. 1993. "Idea Gaps and Object Gaps in Economic Development." Journal of Monetary Economics 32: 543-573.

Schivardi, F., and E. Viviano. 2011. "Entry Barriers in Retail Trade." The Economic Journal 121 (551): 145170.

Sokoloff, K. L. 1988. "Inventive Activity in Early Industrial America: Evidence from Patent Records, 17901846." The Journal of Economic History 48 (04): 813-850.

St. Aubyn, M., A. Pina, F. Garcia, and J. Pais. 2009. "Study on the Efficiency and Effectiveness of Public Spending on Tertiary Education." European Economy Economic Papers 390. European Commission, Brussels.

Straub, S. 2011. "Infrastructure and Development: A Critical Appraisal of the Macro-Level Literature." Journal of Development Studies 47 (5): 683-708.

Summers, L. H. 2014. "Reflections on the 'New Secular Stagnation Hypothesis'." In Secular Stagnation: Facts, Causes, and Cures, 27-40. Center for Economic Policy Research. London: UK.

Teulings, C., and R. Baldwin, eds. 2014. Secular Stagnation: Facts, Causes, and Cures. Center for Economic Policy Research. London: UK.

UNCTAD (United Nations Conference on Trade and Development). 2014. "Investment in SDGs: an Action Plan." World Investment Report. New York: United Nations.

Nations.

2016. "Investor Nationality: Policy Challenges." World Investment Report. New York: United

Wacziarg, R., and K. H. Welch. 2008. "Trade Liberalization and Growth: New Evidence." The World Bank Economic Review 22 (2): 187-231.

Wagstaff, A., C. Bredenkamp, and L. Buisman. 2014. "Progress Toward the Health MDGs." Policy Research Working Paper 6894, World Bank, Washington, DC.

Warner, M. A. 2014. "Public Investment as an Engine of Growth." Working Paper 14/148. International Monetary Fund, Washington, DC.

Wei, M., S. Patadia, and D. Kammen. 2010. "Putting Renewables and Energy Efficiency to Work: How Many Jobs Can the Clean Energy Industry Generate in the U.S.?" Energy Policy 38 (2): 919-931

Weil, D. 2014. "Health and Economic Growth." Handbook of Economic Growth 2: 623-682.

Whited, T. 1992. "Debt, Liquidity Constraints, and Corporate Investment: Evidence from Panel Data." Journal of Financial Economics 47 (4): 1425-1460.

Wilson, J. S., C. Mann, and Y. Pau. 2002. "Trade Facilitation: A Development Perspective in the Asia Pacific Region." Asia Pacific Economic Cooperation, Singapore.

Winthrop, R., G. Bulloch, P. Bhatt, and A. Wood. 2013. Investment in Global Education: a Strategic Imperative for Business. Washington, DC: Brookings Institution. 
World Bank. 2005. World Development Report 2005: Better Investment Climate for Everyone. Washington, DC: World Bank. 2007. World Development Report 2007: Development and the Next Generation. Washington DC: World Bank. 2009. World Development Report 2009: Reshaping Economic Geography. Washington DC: World Bank. 2015a. Commodities Markets Outlook. World Bank, Washington, DC. 2015b. Having Fiscal Space and Using It. Global Economic Prospects January 2015. Washington, DC: World Bank.

2015c. The Global Economy in Transition. Global Economic Prospects June 2015. Washington, DC: World Bank. . 2015d. Development Goals in an Era of Demographic Change. Global Monitoring Report 2015/2016. Washington, DC: World Bank. 2015e. Bangladesh-Public Expenditure Review Update: An Update of Fiscal Trends Based on the 2010 Public Expenditure Review. Washington, DC: World Bank. . 2015f. Progress Towards Sustainable Energy 2015. Global Tracking Framework Report. Washington, DC: World Bank. . 2016a. Spillovers amid Weak Growth. Global Economic Prospects January 2016. Washington, DC: World Bank. Bank. . 2016b. Divergences and Risks: Global Economic Prospects June 2016. Washington, DC: World 2016c. Ethiopia-Public Expenditure Review. Washington, DC: World Bank. 2016d. Mexico-Public Expenditure Review. Washington, DC: World Bank. 2016e. South Asia Economic Focus: Investment Reality Check. World Bank, Washington, DC. . 2017. Weak Investment in Uncertain Times. Global Economic Prospects. January 2017. Washington, DC: World Bank.

Xing, R., J. Sun, and J. Zheng. 2016. "Five Debates about the Private Investment Slump." Morgan Stanley Research.

Zhang J., J. Zhang, and R. Lee. 2003. "Rising Longevity, Education, Savings, and Growth." Journal of Development Economics 70: 83-101. 